


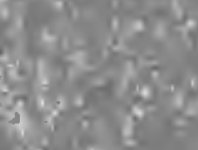 \\ 20.

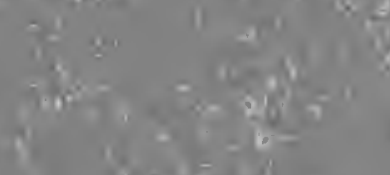

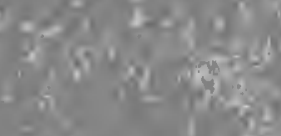 \\ $94 x^{2}$}

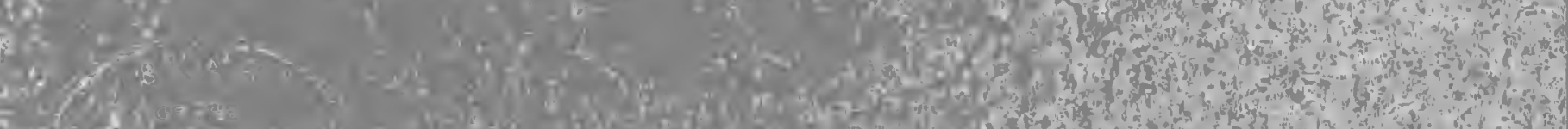

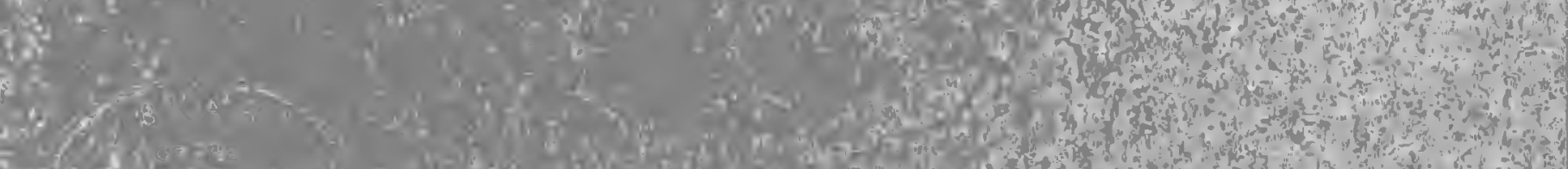

conding

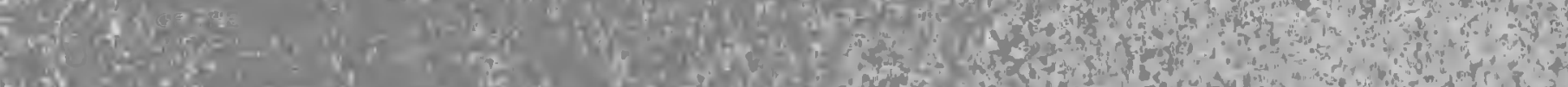
and

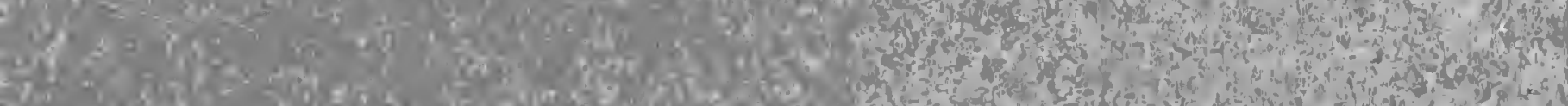

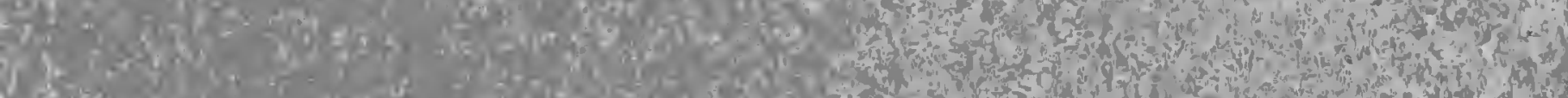

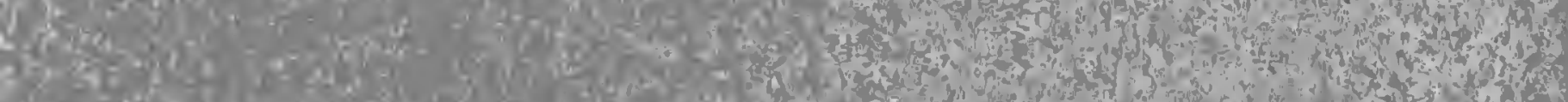

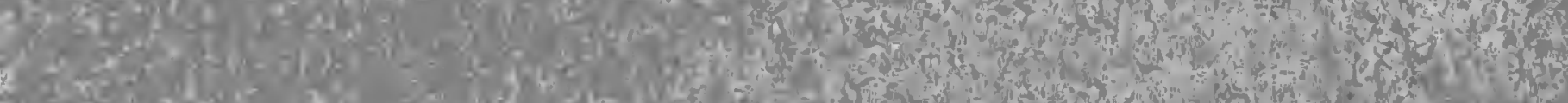
E.

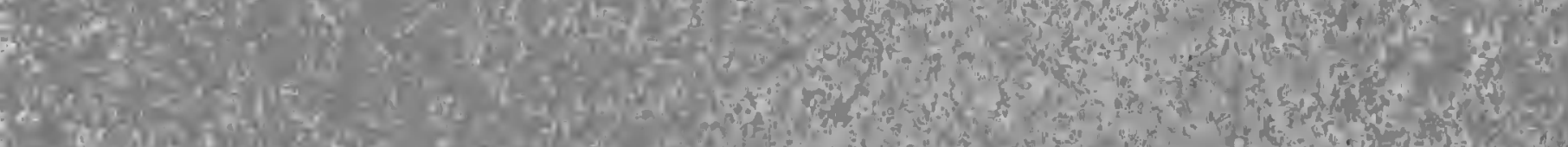

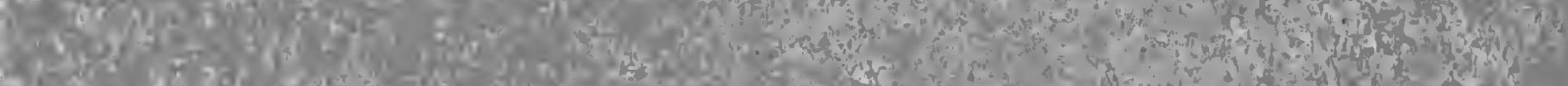

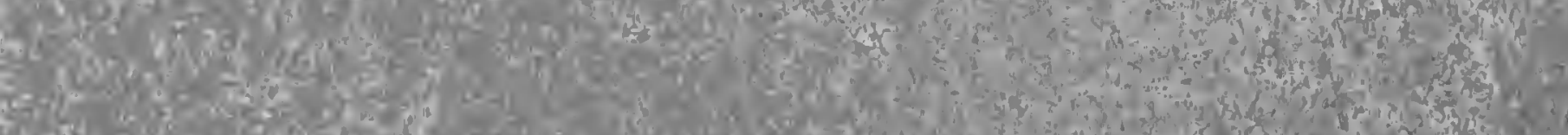

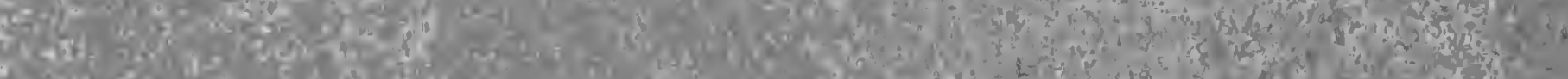

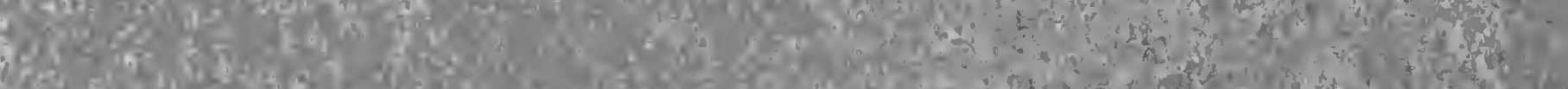

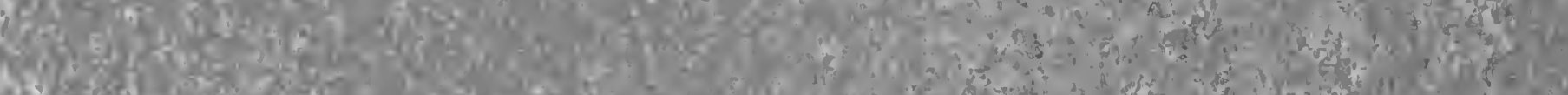
Q6.

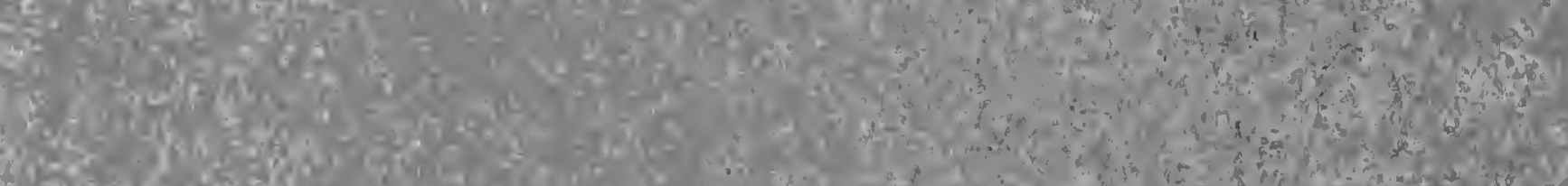

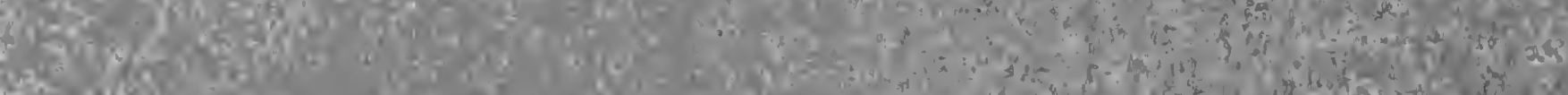
Exy

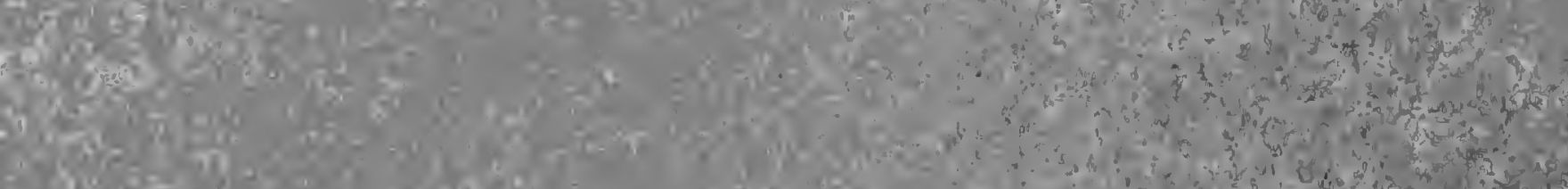

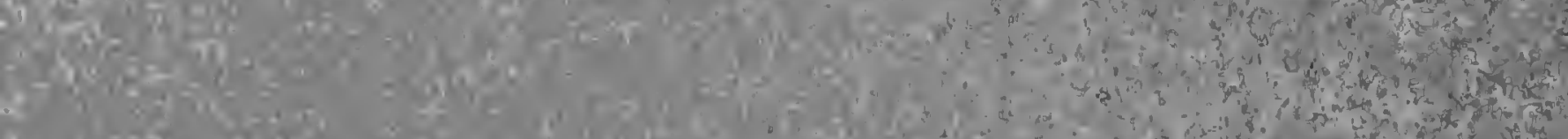
19. a d

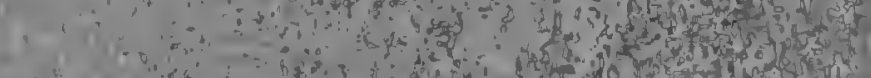
and a to

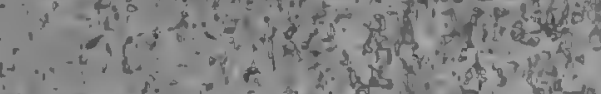

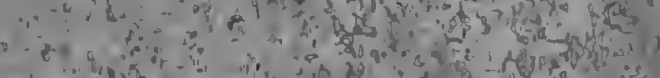

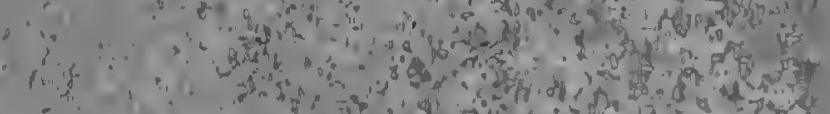
$\therefore \quad-1040$ 1. 100 a $\therefore \quad, \quad 1,0$ $\therefore=0$ ind

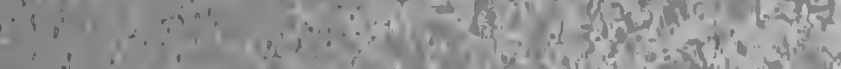

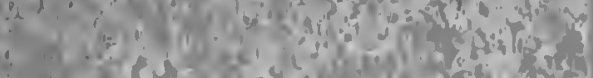

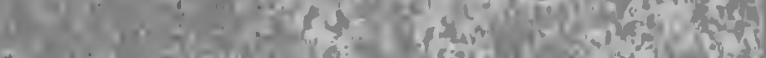




\section{4.}

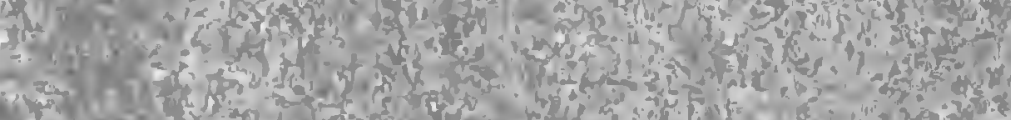
F.

1.5.

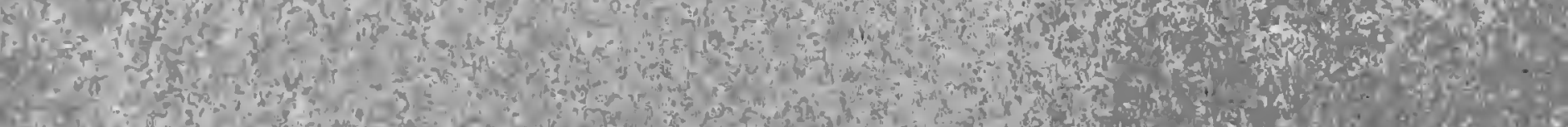

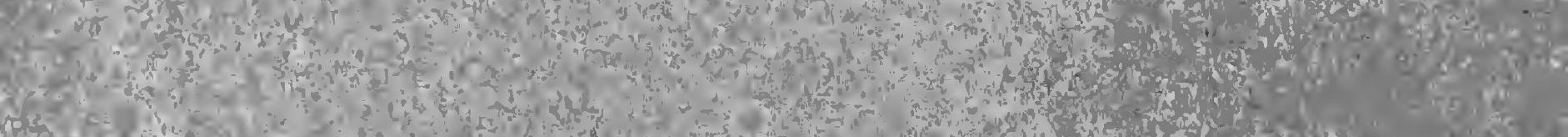
(1925) act 1. W 1.250 10.4. 190 W. W. ing

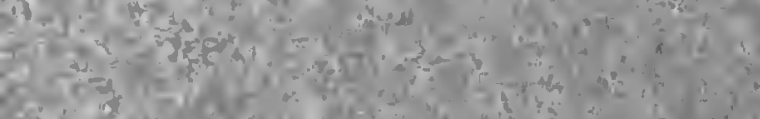

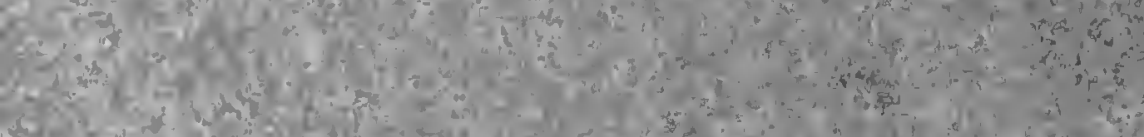

(1) (x)

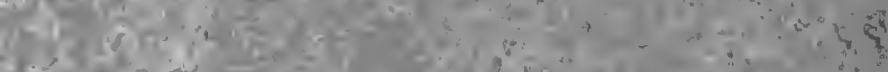
and 


\title{
NEWSPAPER PUBLICITY FOR THE \\ PUBLIC SCHOOLS
}

\author{
BY
ROLLO GEORGE(REYNOLDS,
}

Submitted

in partial fulfillment of the requirements

for the degree of Doctor of Philosophy in the Faculty of Philosophy

Columbia University

NEW YORK, N. Y.

1922 
Copyright, 1922 by Rollo George Reynolds All Rights Reserved

L 32846
R4

Exahanal 


\section{ACKNOWLEDGEMENTS}

Newspaper editors and school superintendents furnished the facts which have made this study possible. Dr. N. L. Engelhardt, Dr. Milo B. Hillegas, Dr. E. S. Evenden and Dr. George D. Strayer of the Teachers College Faculty have brought to this study wise counsel and careful criticism. I realize the debt I owe to the many who have contributed. I wish to express my gratitude to them all.

R. G. R. 


\section{Digitized by the Internet Archive in 2007 with funding from Microsoft Corporation}




\section{CONTENTS}

CHAPTER I. THE SCOPE AND PURPOSE OF THE STUDY................ 9

CHAPTER II. THE AMOUNT AND CHARACTER OF SCHOOL NEWS FOUND IN

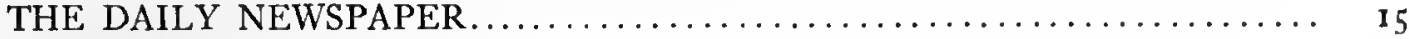

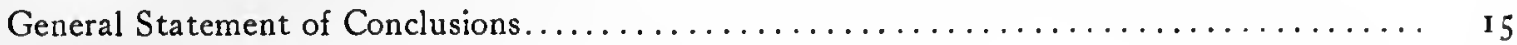

The Material Collected and Method Used................................ I5

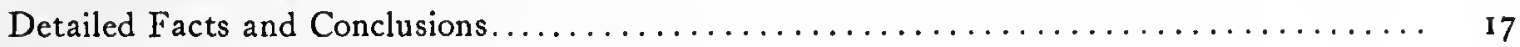

CHAPTER III. SCHOOL NEWS FROM THE EDITOR'S VIEWPOINT.......... 25

General Statement of Conclusions................................. ${ }_{25}$

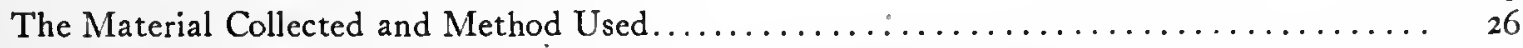

Detailed Facts and Conclusions.................................... 27

CHAPTER IV. SCHOOL NEWS FROM THE SUPERINTENDENT'S VIEWPOINT... 43

General Statement of Conclusions.................................... 43

Material Collected and Method Used................................... 44

Detailed Facts and Conclusions.................................. 45

CHAPTER V. SCHOOL NEWS FROM THE NEWSPAPER READER'S VIEWPOINT 77

General Statement of Conclusions.................................... 77

Material Collected and Method Used................................. 77

A Scale of Newspaper Articles....................................... 79

CHAPTER VI. A PROGRAM FOR SCHOOL INFORMATION SERVICE IN THE DAILY

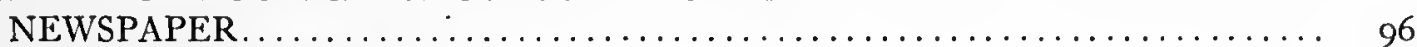

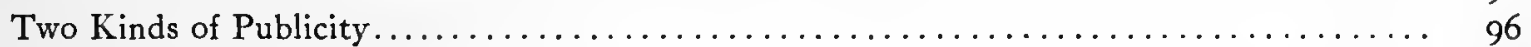

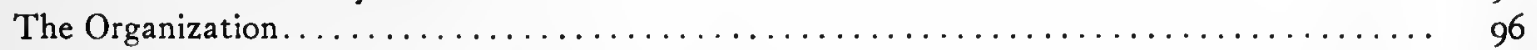

The Financing of School News Service................................ 99

The Collection of School News................................... 99

The Delivery of School News.................................... I03

Relations with the Newspaper Organization.......................... 103

What School News Shall Be Presented?................................ 107

Conclusion.................................... 119

APPENDIX A. List of Newspapers from which the Counts and Measurements were secured I 20

APPENDIX B. List of Daily Newspapers Cooperating in this Study.............. I2I

APPENDIX C. List of Cities in which the Superintendents of Public Schools Cooperated in

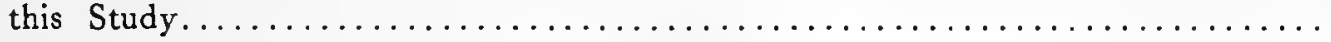




\section{ILLUSTRATIONS}

\begin{tabular}{|c|c|c|}
\hline Figure & & Page \\
\hline I & A Scale of Newspaper Articles. & 79 \\
\hline 2 & Newspaper Article G....... & 83 \\
\hline 3 & Newspaper Article F. & 84 \\
\hline 4 & Newspaper Article I. . & 85 \\
\hline 5 & Newspaper Article B. & 86 \\
\hline 6 & Newspaper Article C. . & 87 \\
\hline 7 & Newspaper Article H.. & 88 \\
\hline 8 & 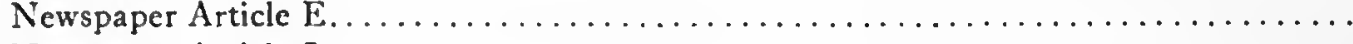 & 89 \\
\hline 9 & 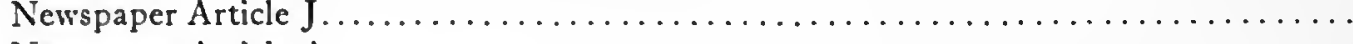 & 90 \\
\hline 10 & 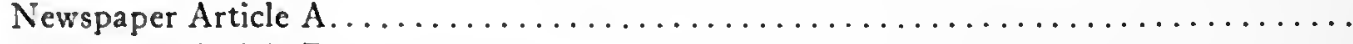 & \\
\hline II & Newspaper Article D....... & \\
\hline 12 & A Special Purpose Display Advertisement. . & 98 \\
\hline $1 \mathbf{3}$ & A School Page Dealing with One Subject.. & 100 \\
\hline 14 & 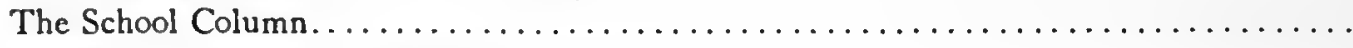 & 102 \\
\hline 15 & 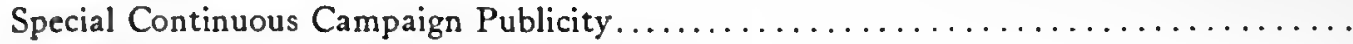 & 104 \\
\hline 16 & Departments Contributed by School Children $\ldots \ldots \ldots \ldots \ldots \ldots \ldots \ldots \ldots \ldots \ldots \ldots \ldots$ & 106 \\
\hline 17 & The Sunday Magazine-An Opportunity.......... & 108 \\
\hline 18 & 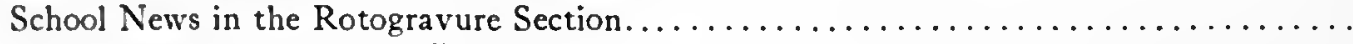 & 110 \\
\hline 19 & 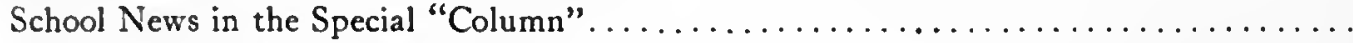 & 112 \\
\hline 20 & Cartoons Adapted to School Publicity......... & 114 \\
\hline $2 I$ & Charts and Graphs in the Newspaper........ & 116 \\
\hline 22 & Public School Display Advertisements.. & 118 \\
\hline 23 & School News of Front Page Importance... & $\mathbf{I}$ \\
\hline 24 & A School Page Dealing with Various Activities......... & 1 \\
\hline 25 & 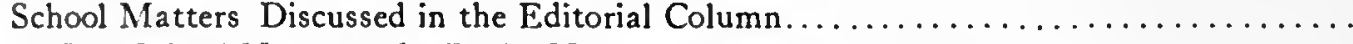 & \\
\hline 26 & A High School Number of a Daily Newspaper. $\ldots \ldots \ldots \ldots \ldots \ldots \ldots \ldots \ldots \ldots \ldots \ldots$ & \\
\hline 27 & icles....................................... & \\
\hline 8 & & \\
\hline
\end{tabular}

Form

I Tabulating Sheet for the Number Count.............................. 20

2 Tabulating Sheet for Column-inch Measurement........................ 22

3 Question Sheet Sent to Newspaper Editors............................. 37

4 Question Sheet Sent to Superintendents of Schools...................... $62-65$

5 Broadside Containing Ten Newspaper Articles......................... 82 


\section{TABLES}

I A Number Count of School News in the Daily Newspaper................. 2 I

II School News Compared with Other Types of News.................... ${ }_{23}$

III How Newspapers Collect School News............................. ${ }_{3}^{8}$

IV Types of School News Found in Daily Newspapers...................... 39

V The Proper Position of School News in the Newspaper..................... 40

VI The Value of Illustrations to School News........................... 40

VII The Value of Charts and Graphs to School News.................... $4^{\text {I }}$

VIII The Demand for School News by Daily Newspapers..................... $4^{\mathrm{I}}$

IX Financing Public School Information Service......................... 66

X Percent of Budget for Public School Information Service.................... 66

XI Organization of School Information Service........................... 66

XII How Public School Systems Collect School News......................... 67

XIII The Centrálized Editing and Approving of School News................... 68

XIV How School News is Edited and Approved............................ 69

XV Relation of School System with Newspapers......................... $7^{\circ}$

XVI Newspapers Having an Educational Editor.......................... $7 \mathbf{7}$

XVII Departments in Newspapers Devoted to School News................... $7_{72}$

XVIII The Attitude of Newspapers toward School Systems...................... 73

XIX Editorial Discussion of School Matters........................... 73

$\mathrm{XX}$ Continuous Campaigns Carried on in the Newspapers.................... 74

XXI The Best Edition for Carrying School News.......................... 75

XXII Median Ranking Given to Ten Newspaper Articles...................... 93

XXIII The Number of "Better" Judgments in Ranking Ten Articles................... 93

XXIV The Number of "Better" Judgments Reduced to Percents................... 94

XXV The Differences Between Ten Newspaper Articles in Terms of the Unit of the Scale. 94 



\section{CHAPTER I}

\section{THE SCOPE AND PURPOSE OF THE STUDY}

\section{NEWSPAPER PUBLICITY FOR THE PUBIIC SCHOOLS}

The daily newspaper is one of the means of informing the public about the public schools. A large number of articles have been written on this subject but they have all been general in content and based merely upon opinion. One study on the subject ${ }^{1}$ includes an opinion of the value of the daily newspaper for carrying school news as collected from II I superintendents of schools; another ${ }^{2}$ includes a classification and analysis of educational news found in a single newspaper over a period of one year.

The purpose of the following study is to present a body of fact relative to the use of the daily newspaper for carrying school news throughout the United States and to draw such conclusions as seem warranted.

The scope of the inquiry is indicated by the following headings:

The Amount and Character of School News Found in the Daily Newspaper.

School News From the Editor's Viewpoint.

School News From the Superintendent's Viewpoint.

School News From the Reader's Viewpoint.

A Program for School Information Service.

\section{THE AMOUNT AND CHARACTER OF SCHOOL NEWS FOUND IN THE DAILY NEWSPAPER}

To furnish the facts for this part of the study, 25 cities were chosen at random, representing various sections of the country. They were selected from the following population groups:

Group I. Cities, 100,000 in population and over.

Group II. Cities, 30,000 to 100,000 in population.

Group III. Cities, less than 30,000 in population.

These cities were distributed over seventeen states, representing five of the geographical divisions of the country. In each city the largest daily newspaper was subscribed to for a period of three ${ }^{1}$ Neale, Mervin G. $\rightarrow$ School Reports in American Cities, p. 60.

${ }^{2}$ Garlin, R. E. and Pittenger, E. F.-Educational Publicity in Daily Newspapers. School Board Journal, December 1921 ; p. 41 . 
months-January, February, and March. The "size" of the news- Scope and paper was determined on the basis of the circulation figures in Ayer's Purpose of American Newspaper Annual and Directory for 1921. A number the Study. count was then made of the news articles dealing with local public school matters. In addition, a column-inch measurement was made of the school news found in six of the above newspapers, two from each of the population groups mentioned. It is believed that the newspapers studied represent a fair sampling of school news in the daily paper. The facts thus collected, analyzed, and tabulated, are presented as evidence of the amount and character of school news found in the daily paper.

\section{SCHOOL NEWS FROM THE EDITOR'S VIEWPOINT}

School news is of two kinds; that which is secured and published independently of school systems, and that which is prepared especially for the newspaper by school systems. In either case it must be passed upon by the newspaper organization. It is therefore necessary to study the practice and opinion of newspaper editors in connection with school news. To secure this information, a question sheet was sent to 200 editors of representative newspapers. Replies were received from 98 editors in cities representing each of the population groups and located in 40 different states. This point of view is most important to those who are responsible for educational publicity. The facts collected from these question sheets will be set forth as representing the practice and viewpoint of newspaper organizations relative to school news in the daily paper.

\section{SCHOOL NEWS FROM THE VIEWPOINT OF THE SUPERINTENDENT OF SCHOOLS}

Information for newspaper publication is often collected and prepared within the school system itself. Therefore, the policies, practices, and opinions of school superintendents relative to the publicity activities of school systems have an important place in this study. A question sheet was sent to 500 superintendents of representative school systems. Replies were received from 250 superintendents in cities representing each of the population groups and located in 45 different states. The facts collected from these question sheets will be set forth as representing the practice and viewpoint of superintendents of schools in relation to the collection, preparation, and pub- 


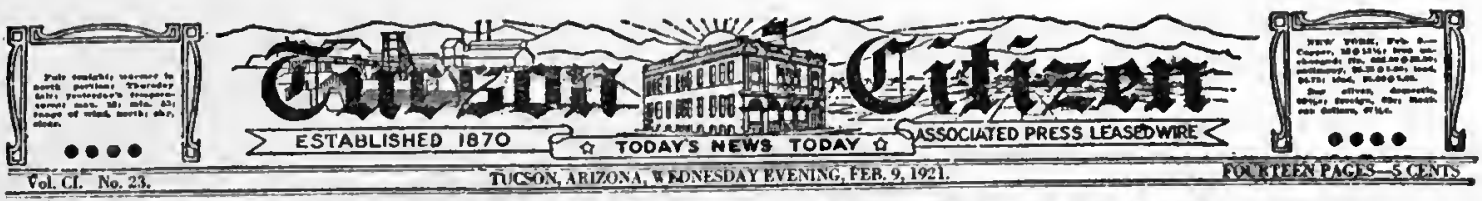

\section{TUCSON MUST HAVE MODERN HIGH SCHOOL OR LOSE HER RANK AMONG INSTITUTIONS} SECESSIDNISTS COOPERATION OF CATTLEMEN ENROLLIMENT GROWS TOPOINT THAT PITER DEBATE HIE DEFEATED IN] COND PACKERS URGED AS ANNUAL CLASSES ARE UNABLE TO FUNCTION

BOARD AND COUNCIL AGREE ON\$300,000SCHOOL BOND ISSUE THE DAILY REPORTER

VOL XIV. NO. 337.

CONDITIONS AMONG HIGH SCHOON BOYS AND GIRLS DISCUSSED AT BIG MEETING OF PARENTS-TEACHERS

Principal Houseman's Talk on "Social Activities in High School," During Which He Condemned Fraternities, Saying 'They Are Detriment to School, Followed by Heated Debate Regarding Alleged Happenings at Dances of Younger Folk; Critics and Defenders Both Are Heard: Principal Stands by Majority of Students; Meeting Votes Confidence in Faculty.

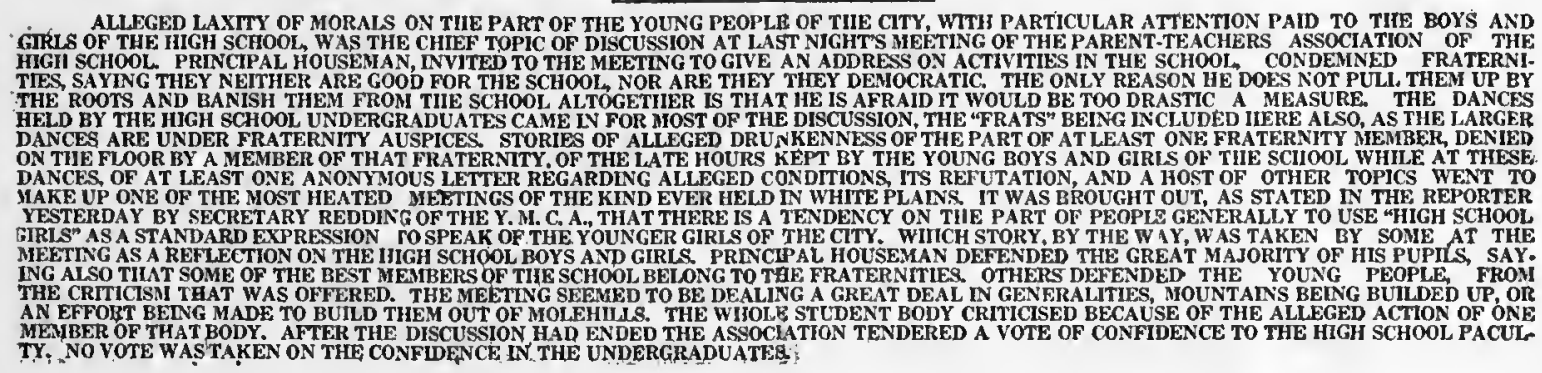

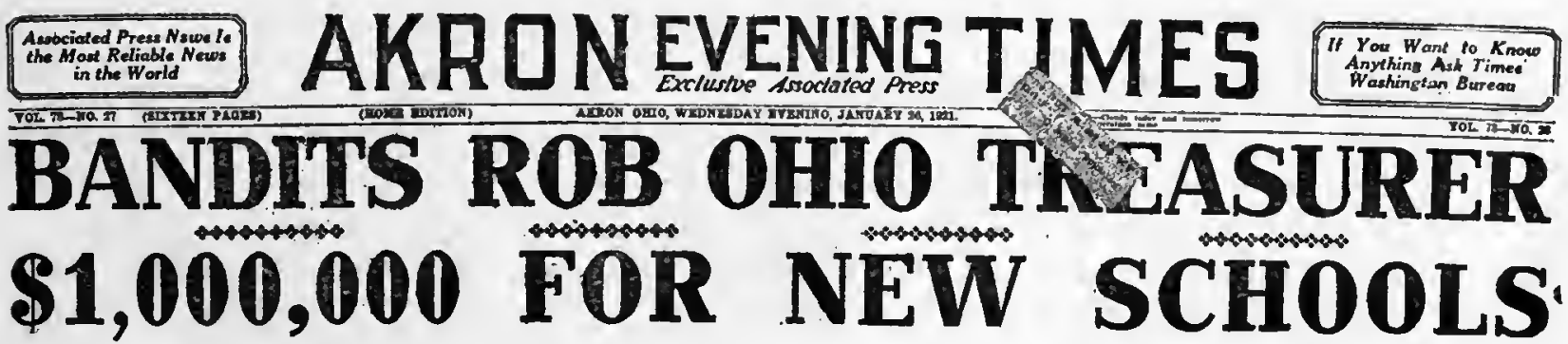

SCHOOL NEWS OF FRONT PAGE IMPORTANCE 
Scope and

Purpose of the Study. lishing of school news in the daily newspaper. It is of interest to note, in the case of both editors and superintendents, that a large per cent, approximately $50 \%$ took pains to fill out the question sheets.

\section{SCHOOL NEWS FROM THE NEWSPAPER READER'S VIEWPOINT}

The "consumer" of school news, the newspaper reading public, is after all the final judge of school news in the daily newspaper. The purpose of all school news is that it shall be read. To complete the study, therefore, an indication of the viewpoint of the newspaper reader is presented. Through a statistical process of selection, Io newspaper articles, each having to do with the health of school children, were chosen for the judgment of newspaper readers. These articles were reproduced on a broadside. The readers were asked to rank them, beginning with that article which gave the greatest interest in the health of school children and ending with that which gave the least interest. Judgments were received from 369 individuals, $\mathbf{I} 28$ women and $24 \mathbf{I}$ men, representing 8 occupational groups and residing in 35 different states. In addition, the judgments of 34 expert women advertisers holding important advertising positions in the city of New York were secured. From these judgments, a scale of the articles has been constructed and is presented as an indication of the relative value which the newspaper reader gives to certain school news articles in the daily newspaper.

\section{A PROGRAM FOR SCHOOL NEWS SERVICE IN THE DAILY PAPER}

The last chapter of the study consists of two parts. First, the presentation of various types of school publicity as clipped from a large number of newspapers and contributed by superintendents of schools; these are presented for the purpose of serving as examples to school organizations desiring to inform the public through the daily newspaper. Second, suggestions for an organized school news service program in the daily newspaper.

\section{HOW THE FACTS WILL BE PRESENTED}

Each chapter will have the following organization: First, a general statement of the conclusions drawn from the material presented in the entire chapter; this will be presented first for the bencfit of those who do not care to go into the details. Second, a discussion of the material collected and the methods used in preparing it for presentation. Third, the specific conclusions drawn 
from each sub-topic taken up in each chapter. Fourth, the tabula- Scope and tion of the facts upon which the conclusions, both general and Purpose of specific,-are based. the Study.

THE PURPOSE OF THE STUDY

The public schools of America belong to the American people and are supported by them. Their interest and support will depend to a large extent upon the information which they possess as to the activities and needs of the public schools. If this study brings to the administrators of American school systems and to the editors of American daily newspapers a conception of the importance of the daily press to the public schools and the conditions which control the use of the newspaper as a means of giving school information to the public, it will have served its purpose. 


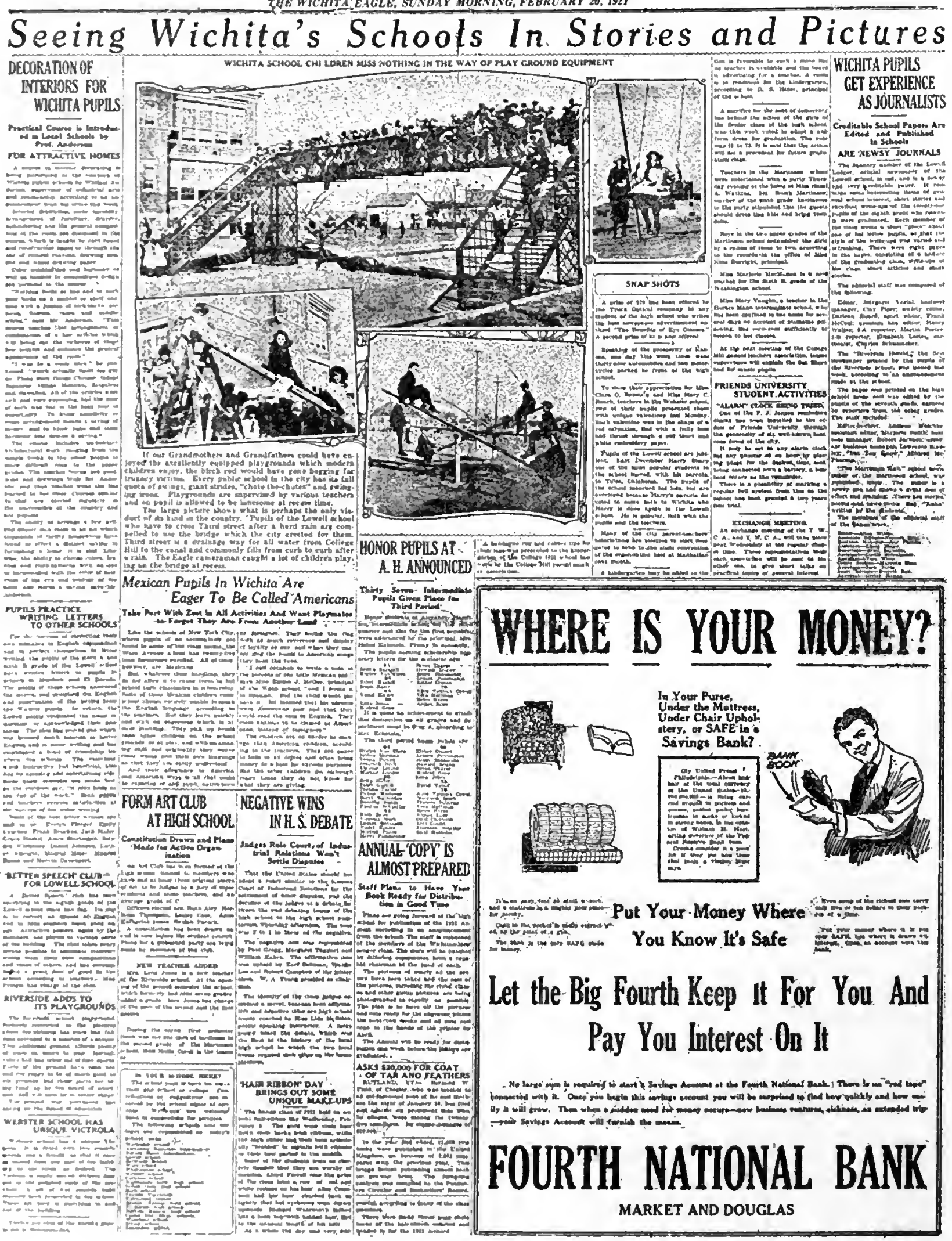

A SCHOOL PAGE DEALING WITH VARIOUS ACTIVITIES 


\section{CHAPTER II}

\section{THE AMOUNT AND CHARACTER OF SCHOOL NEWS FOUND IN THE DAILY NEWSPAPER}

\section{GENERAL STATEMENTS}

The facts presented in this chapter uphold the following statcments:

The local public school system is an important source of news found in the daily press.

In general, the newspaper staff believes in presenting constructive and informational news in regard to the public school. The proportion of school news, sensational or destructive, which is found in the daily newspaper, is extremely small.

The editors of daily papers consider school news of sufficient importance to command place on the front page of the paper and comment in the editorial column. News of public school athletics, in fact, is often given an undue amount of space.

It would seem, therefore, that public school matters are of such importance to the community as to place their emphasis in the daily newspapers at least on a level with the emphasis given to society and professional sport. This is not the case.

Nevertheless, to the school administrator the fact must be evident that the newspapers are furnishing a large amount of information about the public schools to the general public. This medium of school publicity is, therefore, worthy of his consideration, his study, and his cordial cooperation.

The general summary and conclusions given above are based on a reading, analysis, and classification of 1800 newspapers in 25 different states.

\section{MATERIAL COLLECTED AND METHOD USED}

Any selection of newspapers upon which a number count is to be based should include newspapers which offer a wide variety in the amount and character of the school news which they publish. From Table I, page 2I it is clear that this variety was secured. From the list of cities given in the Appendix, Table A, it is evident that the geographical divisions of the country are represented. The newspapers also are fairly distributed among the three population groups: nine cities from Group I (100,000 and over); eleven cities from Group II $(30,000$ to 100,000); and five cities from Group III (less than 
The Period of Reading.

The

Classification of School Newes.

Criteria for Classification of School News.
30,000). The particular newspaper chosen in each city was arbitrarily determined by selecting that paper which was reported in Ayer's American Newspaper Annual and Directory for 1921 as having the largest circulation.

The newspapers were subscribed to for the months of January, February, and March, of I92I. All issues of each paper which were received were read. The non-arrival of certain issues through faulty mail service or other reasons accounts for the fact that the same number of newspapers was not read for each city. The number of Sunday editions read is indicated in the tables. The period of time over which the newspapers were read does not include the opening or closing of the school year. At such times, school news in the newspapers would undoubtedly be heavier. The three months taken, however, probably represent fairly a period during which school news, uninfluenced in amount by special occasions, appears in the daily press.

In the number count, only articles dealing with local public school news were considered. These were classified as read under the following headings: Articles Constructive or Informational in $\mathrm{Na}$ ture, Articles Sensational or Destructive in Nature, and Articles Dealing with Public School Sport. In addition, the number of articles appearing on the front page, the number of editorials dealing with local public school matters, and the number of illustrations accompanying school news aritcles were enumerated.

The judgment of the reader determined the classification of each article. This personal judgment was guided by the following criteria:

I. Constructive or Informational Articles.

a. All announcements, reports of school activities, social events, and the like.

b. News items having to do with the conduct and progress of the school system, such as school building programs, items of school finance, curricula, and the like.

c. News items evidently released by the school system such as school pages, school columns, signed articles, and the like.

d. Personal items relating to students or teaching staff.

2. Destructive or Sensational Articles.

a. All news "playing up" school scandal.

b. News items in which the emphasis was placed on some fad or foible such as short skirts, rouge, hazing. 
c. News items in which the school system was attacked without constructive suggestions.

3. Articles Dealing with School Sport.

Classification self determined.

4. Editorials.

Only such as dealt with local public school matters.

\section{DETAILED FACTS AND CONCLUSIONS}

Specific Conclusions Based on a Number Count of Newspapers IN 25 Cities

A Number Count

of School Nerws

As a result of the newspaper reading described, and from the in Daily data tabulated in the tables, the following conclusions seem war- Newspapers. ranted.

I. The number of local school news items found in the daily newspapers is large enough to warrant careful consideration. In 1800 newspapers from 25 cities, 5483 such articles or items were found. Individual cities vary in the number of items relating to school news, but considered in the three population groups the variation is slight.

2. School matters are evidently considered good news by the daily newspapers.

3. The bulk of school news in the daily press is constructive or informational. Table I, page 21 shows that $64 \%$ of all school news items are of this character. Individual cities vary considerably from this amount, but the variation of the three groups is negligible.

4. The number of sensational items relating to school matters is extremely small. Only $5 \%$ of all school newsitems are of this type. Newspapers in cities of Group I are more prone to print this kind of news.

5. The number of news items relating to school sport is relatively large. Of all school news items $30 \%$ deals with sport. Newspapers in cities of Group II seem to specialize heavily in news of public school sport.

6. The proportion of school news considered of front page importance is small. Of all school news $5 \%$ is of front page importance. This varies little for all three population groups. 
Tabulation of Number Count.

The

Column-Inch Measurement.
7. Editorial discussion of school matters is fairly frequent. Of all the items relating to school matters $4 \%$ is found in the editorial column. Considering the limited space devoted to editorials, this percentage is relatively larger than the $5 \%$ of school news items which appears on the front page. More editorials dealing with school matters were found in newspapers of Group I.

8. About one in every ten items on school matters is accompanied by an illustration. Cities of Group III fall short in the number of illustrations used.

In Table I, page $2 \mathrm{I}$ the measure of school news is expressed in terms of numbers of articles having to do with local public school matters. In the count, one article is equivalent to any other article, without reference to space. The table reports the frequency with which school news appears and, in so far as this element is concerned, is an indication of the importance of school affairs as news to the daily press. If anything, the number count reported falls short of the actual number of school news items appearing in the newspapers studied. No doubt some items were overlooked in the reading.

The news items found in each issue of a newspaper were recorded on a tabulating sheet similar to Form I, page 20.

The results obtained are found in Table I, page $2 \mathbf{I}$.

\section{Specific Conclusions Based on Column Inch Measurement of}

\section{Newspapers in 6 Cities}

I. The amount of space given to local school news by the daily newspapers is considerable. In I 44 newspapers, 4645 column inches of space were devoted to public school news.

2. Cities of Group III lead in the number of column inches given to this kind of news.

3. The space given to school news constructive or informational in character is relatively large. Of all school news in the six newspapers studied $66 \%$ is of this character. Cities of Group II rank the lowest in this particular.

4. The amount of space given to destructive or sensational news is extremely small of all school news in the six newspapers studied $5 \%$ is of this character. Cities of Group III devote a relatively large proportion of their space to this type of news. 
The amount of space devoted to public school sport is relatively great. In the six cities studied $30 \%$ of the space devoted to schools dealt with public school sport. Cities of Group II lead in the amount of space devoted to sport.

6. The editorial column devotes considerable of its space to the discussion of school matters. In the six newspapers studied $4 \%$ of all the space devoted to local school matters is found in the editorial column.

7. Much less space is given to local public school news than is given to either "Society" news or news of professional sport. Of 27,299 column-inches of space devoted to local school news, educational news other than local public, society news, and professional sport,professional sport stood first with $42 \%$, society news second with $31 \%$, local public school news third with $17 \%$, and other educational news fourth with $9 \%$.

8. School news is well illustrated as compared with news of professional sport and society news. In the six newspapers studied, society news leads with one illustration to every $8 \mathrm{I}$ column-inches of space, local public school news second with one illustration to every I4I columninches, and professional sport news third with one illustration to every 170 column-inches.

School news items, items under the heading "Society", and Tabulation items relating to professional sport, were measured in six of the news- of Column-Inch papers included in the number count, two from each of the three pop- Measurement. ulation groups. These were chosen as typical of the larger group of 25 newspapers. They were read for the month of February. The criteria for the classification of the school news articles were the same as those which governed in the number count: Under society news all items were included which were published in the newspaper under the heading, "Society News", "Social Happenings", and the like. The other classifications used are self-determining. The statement which was made relative to the accuracy of the number count can be applied to the columns-inch measurement.

The column inches found in each issue of a newspaper were recorded on a tabulating sheet similar to Form 2, page 22.

The results obtained are found in Table II, page 23. 
FORM 1.

TABULATING SHEET FOR THE NUMBER COUNT OF SCHOOL NEWS ITEMS IN DAILY NEWSPAPERS

\begin{tabular}{|c|c|c|c|c|c|c|c|c|}
\hline $\begin{array}{l}\text { AKRON } \\
\text { BOISE } \\
\text { BUFFALO }\end{array}$ & $\begin{array}{l}\text { DEC. } \\
\text { JAN. } \\
\text { FEB. }\end{array}$ & $\begin{array}{l}1-2-3 \\
31\end{array}$ & $-7-8-9-$ & $-11-12$ & $-14-15$ & $7-18-19$ & $23-24-25-2$ & $28-29-30$ \\
\hline $\begin{array}{l}\text { CANTON } \\
\text { DAVENPORT } \\
\text { DENVER }\end{array}$ & $\begin{array}{l}\text { MAR. } \\
\text { APR. } \\
\text { MAY }\end{array}$ & Loc. & $\begin{array}{l}\text { Loc. } \\
\text { 1sT PQ. }\end{array}$ & $\begin{array}{l}\text { LOC. } \\
\text { ILL. }\end{array}$ & $\begin{array}{l}\text { LOC. } \\
\text { EDIT. }\end{array}$ & $\begin{array}{c}\text { INF. OR } \\
\text { CONSTR. }\end{array}$ & $\begin{array}{l}\text { SENSAT. } \\
\text { DESTRUC. }\end{array}$ & SPORT \\
\hline DES MOINES & JUNE & & & & & & & \\
\hline DETROIT & JULY & & & & & & & \\
\hline GREAT FALIS & Avo. & & & & & & & \\
\hline HAVERHILL & SEPT. & & & & & & & \\
\hline LINCOLN & Oct. & & & & & & & \\
\hline IONG BEACH & Nov. & & & & & & & \\
\hline MANCHESTER & & & & & & & & \\
\hline MUSKEGON & & & & & & & & \\
\hline NEWARK & & & & & & & & \\
\hline OAKLAND & & & & & & & & \\
\hline ROCHESTER & & & & & & & & \\
\hline ROCKFORD & & & & & & & - & \\
\hline SALT LAKE & & & & & & & & \\
\hline SAN DIEGO & & & & & & & & \\
\hline SCRANTON & & & & & & & & \\
\hline SEATTLE & & & & & & & & \\
\hline SPOKANE & & & & & & & & . \\
\hline WHITE PLAINS & & & & & & & & \\
\hline WICHITA & & & & & & & & \\
\hline
\end{tabular}




\begin{tabular}{|c|c|c|c|c|c|c|c|c|}
\hline & 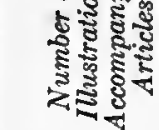 & 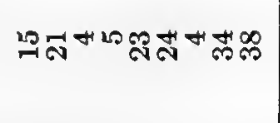 & $\stackrel{\infty}{:}$ & 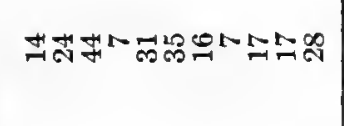 & 온 & 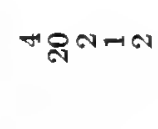 & ने & $\mid$ \\
\hline & 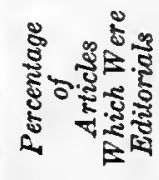 & 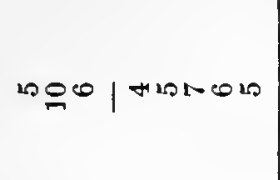 & 0 & NNNHAN" NOON & $\infty$ & $\pi+\infty \infty_{\infty}^{\infty}$ & $\infty$ & $\pi$ \\
\hline & 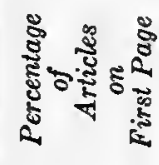 & HNล⿻コ一⿻上丨 & $\rightarrow$ & 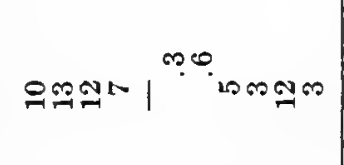 & $\infty$ & $1^{\circ}{ }^{\circ} \overbrace{}^{N}$ & 0 & 10 \\
\hline 幽畨 & 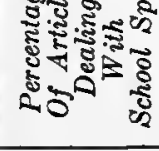 & 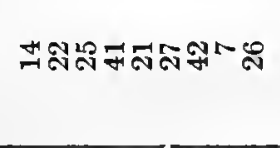 & กิ & 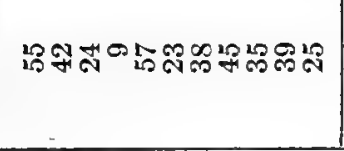 & 吕 & 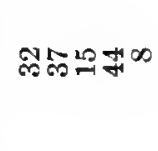 & 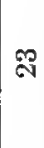 & คి \\
\hline 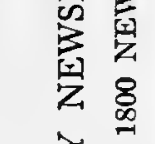 & 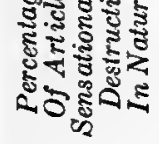 & 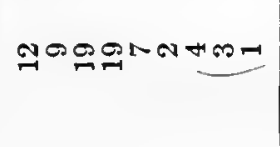 & $\infty$ & 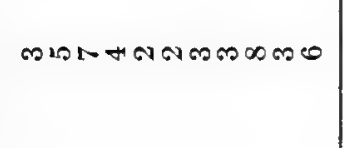 & $\infty$ & mNont & $\pi$ & $\pi$ \\
\hline 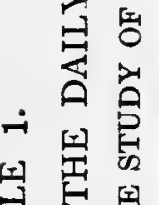 & 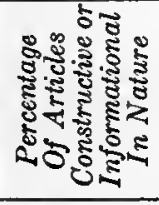 & 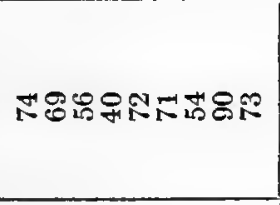 & ล & 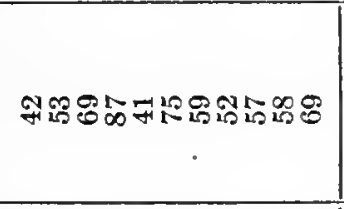 & $\begin{array}{l}\infty \\
20\end{array}$ & ํㅗㅇำ & $\mathfrak{N}$ & 18 \\
\hline 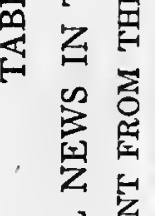 & 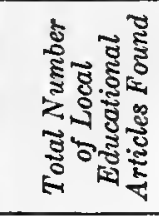 & 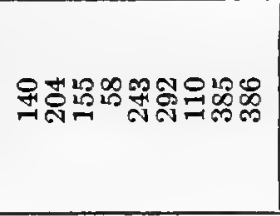 & 足 & 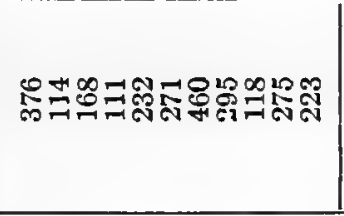 & : & 象: & $\begin{array}{l}5 \\
\infty \\
\infty\end{array}$ & 竞 \\
\hline 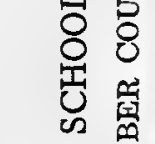 & 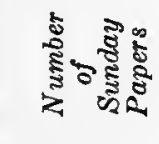 & 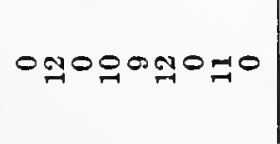 & 80 & $=9= \pm 00070 \mathrm{~N}$ & 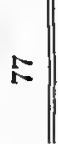 & $0=000$ & ฉి & 둑 \\
\hline $\begin{array}{l}\text { 量 } \\
\end{array}$ & 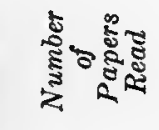 & 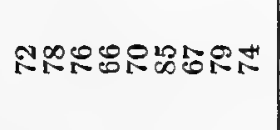 & 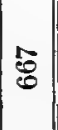 & 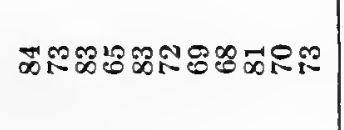 & $\bar{\aleph}$ & 8동ํำ & लै & 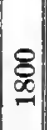 \\
\hline & 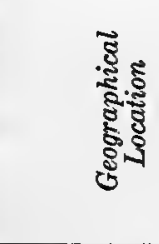 & 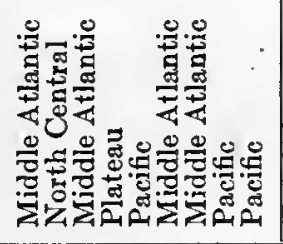 & & 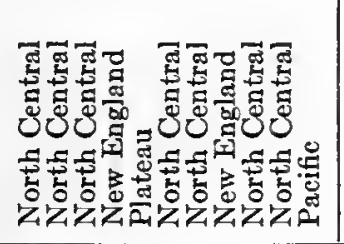 & & 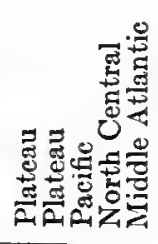 & & \\
\hline & : & 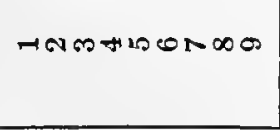 & & 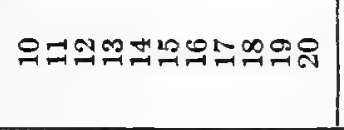 & & สีผิ็ี & & \\
\hline & कृष & 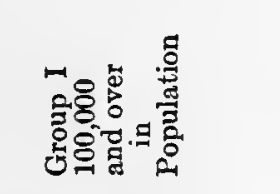 & 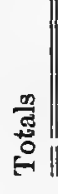 & 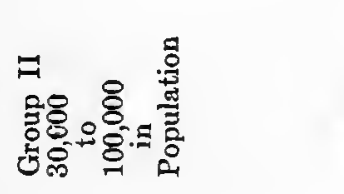 & 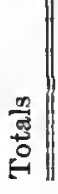 & 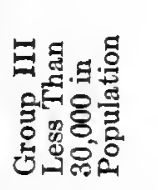 & $\overbrace{}^{\infty}$ & \\
\hline
\end{tabular}




\section{FORM 2.}

TABULATING SHEET FOR COLUMN-INCH MEASUREMENT

PAPER .

I. LOCAL EDUCATIONAL NEWS.

\begin{tabular}{l|c|c|c|c|}
\hline & No. & In. & Pg. & Pos. \\
\hline EDITORIAL & & & & \\
\hline ATHLETIC & & & & \\
\hline CONSTRUCTIVE & & & & \\
\hline III. SOCIETY NEWS (SO LABEIED) & & & \\
\hline INONOSOCIAL & & & & \\
\hline TIONAL OR & & & & \\
\hline ANNOUNCE \\
MIENT
\end{tabular}

TOTAL
II. EDUC. NEWS OTHER THAN PUBLIC LOCAL

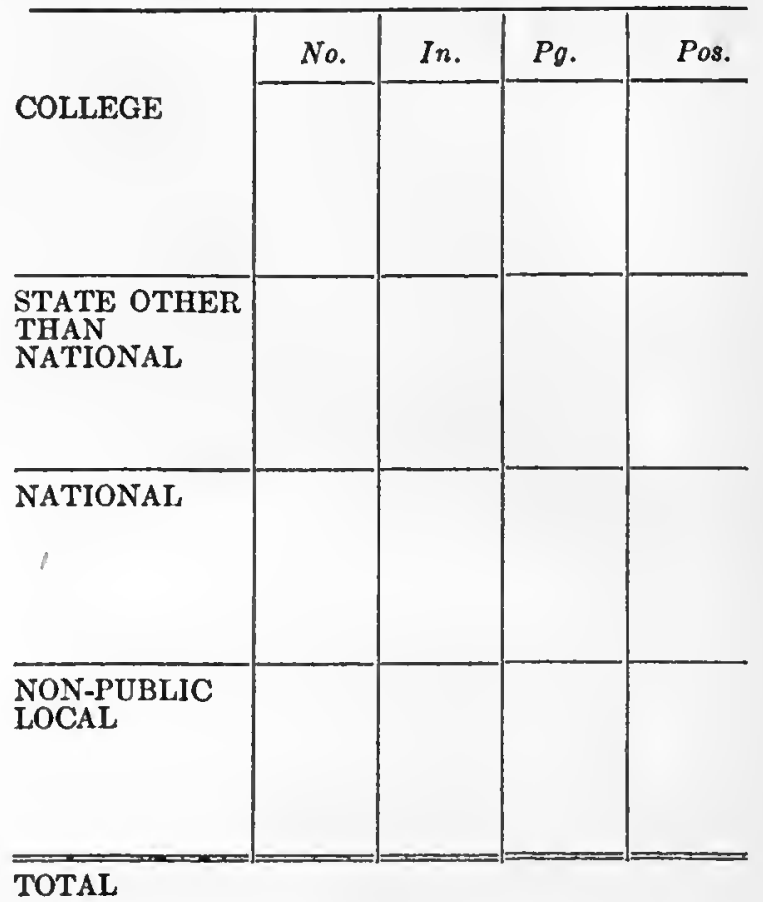

Phot. Graph.

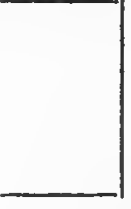

IV. SPORT OTHER THAN PUBLIC LOCAL

\begin{tabular}{|l|l|l|l|l|l}
\hline No. & In. & Pg. & Pos. & Phol. & Graph. \\
& & & & & \\
\hline
\end{tabular}

TOTAL 
TABLE II.

SPACE DEVOTED TO LOCAL SCHOOL NEWS COMPARED WITH THAT DEVOTED TO SOCIETY, PROFESSIONAL ATHLETICS, AND EDUCATIONAL NEWS NOT PUBLIC LOCAL

1. NEWS DEVOTED TO THE LOCAL PUBLIC SCHOOLS IN COLUMN INCHES

\begin{tabular}{|c|c|c|c|c|c|c|c|c|c|}
\hline City & $\begin{array}{l}\text { Population } \\
\text { Group }\end{array}$ & $\begin{array}{c}\text { Number } \\
\text { Papers } \\
\text { Read }\end{array}$ & $\begin{array}{c}\text { Number } \\
\text { Sunday } \\
\text { Edi- } \\
\text { tions }\end{array}$ & $\begin{array}{l}\text { Total } \\
\text { Column } \\
\text { Inches }\end{array}$ & $\begin{array}{l}\text { Percent } \\
\text { of Con- } \\
\text { struc- } \\
\text { tive } \\
\text { School } \\
\text { Newos }\end{array}$ & $\begin{array}{l}\text { Percent } \\
\text { of } \\
\text { School } \\
\text { Ath- } \\
\text { letic } \\
\text { News }\end{array}$ & $\begin{array}{l}\text { Percent } \\
\text { of Sen- } \\
\text { sation- } \\
\text { al or } \\
\text { Destructive } \\
\text { School } \\
\text { News }\end{array}$ & $\begin{array}{l}\text { Percent } \\
\text { of Ed- } \\
\text { itori- } \\
\text { als on } \\
\text { Local } \\
\text { School } \\
\text { Matters }\end{array}$ & $\begin{array}{c}\text { Number } \\
\text { of } \\
\text { Culs } \\
\text { Used } \\
\text { With } \\
\text { School } \\
\text { News }\end{array}$ \\
\hline $\begin{array}{l}\mathbf{A} \\
\mathbf{B} \\
\mathrm{C} \\
\mathbf{D} \\
\mathbf{E} \\
\mathbf{F}\end{array}$ & $\begin{array}{l}\text { Group I } \\
\text { Group I } \\
\text { Group II } \\
\text { Group II } \\
\text { Group III } \\
\text { Group III }\end{array}$ & $\begin{array}{l}23 \\
24 \\
28 \\
24 \\
23 \\
22\end{array}$ & $\begin{array}{l}2 \\
0 \\
4 \\
0 \\
0 \\
0\end{array}$ & $\begin{array}{r}315 \\
440 \\
904 \\
901 \\
1129 \\
956\end{array}$ & $\begin{array}{l}63 \\
67 \\
37 \\
47 \\
86 \\
86\end{array}$ & $\begin{array}{r}35 \\
31 \\
61 \\
48 \\
11 \\
7\end{array}$ & $\begin{array}{r}1 \\
2 \\
1 \\
5 \\
3 \\
14\end{array}$ & $\begin{array}{r}23 \\
6 \\
2 \\
0 \\
4 \\
3\end{array}$ & $\begin{array}{r}3 \\
9 \\
11 \\
5 \\
3 \\
2\end{array}$ \\
\hline ALI & TIES & 144 & 6 & 4645 & 66 & 29.5 & 5 & 4 & 33 \\
\hline
\end{tabular}

2. EDUCATIONAL NEWS OTHER THAN LOCAL PUBLIC SCHOOL IN COLUMN INCHES

\begin{tabular}{|c|c|c|c|c|c|c|c|c|}
\hline City & $\begin{array}{l}\text { Population } \\
\text { Group }\end{array}$ & $\begin{array}{l}\text { Number } \\
\text { Papers } \\
\text { Read }\end{array}$ & $\begin{array}{l}\text { Number } \\
\text { Sunday } \\
\text { Edi- } \\
\text { tions }\end{array}$ & $\begin{array}{c}\text { Tolal } \\
\text { Column } \\
\text { Inches of } \\
\text { Educational } \\
\text { Newos Other } \\
\text { Than Public } \\
\text { Local }\end{array}$ & $\begin{array}{l}\text { Percent } \\
\text { of } \\
\text { College } \\
\text { News }\end{array}$ & $\begin{array}{l}\text { Percent } \\
\text { of } \\
\text { State } \\
\text { Educa- } \\
\text { tional } \\
\text { News }\end{array}$ & $\begin{array}{c}\text { Percent of } \\
\text { National } \\
\text { Educational } \\
\text { News }\end{array}$ & $\begin{array}{l}\text { Percent of } \\
\text { Non-Public } \\
\text { Local } \\
\text { School } \\
\text { News }\end{array}$ \\
\hline $\begin{array}{l}\mathbf{A} \\
\mathbf{B} \\
\mathrm{C} \\
\mathrm{D} \\
\mathrm{E} \\
\mathbf{F}\end{array}$ & $\begin{array}{l}\text { Group I } \\
\text { Group I } \\
\text { Group II } \\
\text { Group II } \\
\text { Group III } \\
\text { Group III }\end{array}$ & $\begin{array}{l}23 \\
24 \\
28 \\
24 \\
23 \\
22\end{array}$ & $\begin{array}{l}2 \\
0 \\
4 \\
0 \\
0 \\
0\end{array}$ & $\begin{array}{r}524 \\
604 \\
764 \\
495 \\
105 \\
42\end{array}$ & $\begin{array}{r}85 \\
80 \\
67 \\
72 \\
31 \\
100\end{array}$ & $\begin{array}{r}1 \\
29 \\
6 \\
19 \\
38 \\
\end{array}$ & $\begin{array}{r}7 \\
6 \\
15 \\
5 \\
30 \\
-\end{array}$ & $\begin{array}{r}- \\
12 \\
5 \\
- \\
-\end{array}$ \\
\hline \multicolumn{2}{|c|}{ Ale 6 Citjes } & 144 & 6 & 2534 & 74 & 16 & 10 & 5 \\
\hline
\end{tabular}

3. SPORT OTHER THAN PUBLIC SCHOOL IN COIUMN INCHES

\begin{tabular}{|c|c|c|c|c|c|}
\hline City & $\begin{array}{l}\text { Population } \\
\text { Group }\end{array}$ & $\begin{array}{l}\text { Number } \\
\text { Papers } \\
\text { Read }\end{array}$ & $\begin{array}{l}\text { Number } \\
\text { Sunday } \\
\text { Editions }\end{array}$ & $\begin{array}{c}\text { Total Number } \\
\text { Column Inches } \\
\text { Devoted to Sport Other } \\
\text { Than Public School }\end{array}$ & $\begin{array}{c}\text { Number of Cities } \\
\text { Used with Sport } \\
\text { News }\end{array}$ \\
\hline $\begin{array}{l}\text { A } \\
\text { B } \\
\text { C } \\
\text { D } \\
\text { E } \\
\text { F }\end{array}$ & $\begin{array}{l}\text { Group I } \\
\text { Group I } \\
\text { Group II } \\
\text { Group II } \\
\text { Group III } \\
\text { Group III }\end{array}$ & $\begin{array}{l}23 \\
24 \\
28 \\
24 \\
23 \\
22\end{array}$ & $\begin{array}{l}2 \\
0 \\
4 \\
0 \\
0 \\
0\end{array}$ & $\begin{array}{r}3577 \\
914 \\
4461 \\
1469 \\
1026 \\
128\end{array}$ & $\begin{array}{r}13 \\
11 \\
39 \\
2 \\
0 \\
3\end{array}$ \\
\hline \multicolumn{2}{|c|}{ All 6 Citres } & 144 & 6 & 11575 & 68 \\
\hline
\end{tabular}

4. SOCIETY NEWS IN COLUMN INCHES

\begin{tabular}{|c|c|c|c|c|c|}
\hline City & $\begin{array}{l}\text { Population } \\
\text { Group }\end{array}$ & $\begin{array}{l}\text { Number } \\
\text { Papers } \\
\text { Read }\end{array}$ & $\begin{array}{l}\text { Number } \\
\text { Sunday } \\
\text { Editions }\end{array}$ & $\begin{array}{c}\text { Total Number } \\
\text { Column. Inches } \\
\text { Devoted to } \\
\text { Society News }\end{array}$ & $\begin{array}{c}\text { Number of Cities } \\
\text { Uscd with Society } \\
\text { News }\end{array}$ \\
\hline $\begin{array}{l}\mathrm{A} \\
\mathrm{B} \\
\mathrm{C} \\
\mathrm{D} \\
\mathrm{E} \\
\mathrm{F}\end{array}$ & $\begin{array}{l}\text { Group I } \\
\text { Group I } \\
\text { Group II } \\
\text { Group II } \\
\text { Group III } \\
\text { Group III }\end{array}$ & $\begin{array}{l}23 \\
24 \\
28 \\
24 \\
23 \\
22\end{array}$ & $\begin{array}{l}2 \\
0 \\
4 \\
0 \\
0 \\
0\end{array}$ & $\begin{array}{r}2141 \\
968 \\
1520 \\
2243 \\
1246 \\
427\end{array}$ & $\begin{array}{r}52 \\
20 \\
20 \\
11 \\
3 \\
0\end{array}$ \\
\hline \multicolumn{2}{|c|}{ All 6 Cities } & 144 & 6 & 8545 & 106 \\
\hline
\end{tabular}

5. SUMMARY TABLE IN COLUMN INCHES

\begin{tabular}{c|c|c|c|c|c}
\hline & $\begin{array}{c}\text { Total Column } \\
\text { Inches Devoled } \\
\text { to All Four } \\
\text { Items }\end{array}$ & $\begin{array}{c}\text { Percent of } \\
\text { Local Public } \\
\text { School News }\end{array}$ & $\begin{array}{c}\text { Percent of } \\
\text { Educational } \\
\text { News Other Than } \\
\text { Local Public School }\end{array}$ & $\begin{array}{c}\text { Percent } \\
\text { of } \\
\text { Society } \\
\text { News }\end{array}$ & $\begin{array}{c}\text { Percent of } \\
\text { Sport News } \\
\text { Other Than } \\
\text { Public School }\end{array}$ \\
\hline ALl 6 Crrues & 27299 & 17 & 9 & 31 & 42 \\
\hline
\end{tabular}




\section{IIMLS PHINIING LUMPAMY Ut JLAI ILt

$\mathrm{N}^{\circ}$

O REASONABLE OBJECTION can be raised to the demand of the Seattle school authorities that students in the High Schools should pass in three out of foul' subjects in each semester.

The courses of study in these institutions are not nof ably difficult.

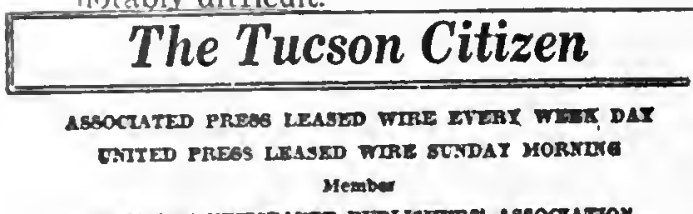

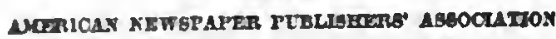
ACDT BCREA OF CIRUTLATION

ARZONA DAIT NEWEPAFER ASGOCUTOX

\section{BOISE SCHOOLS}

The guafostros foubsties of the re"lveat of correepondent theres that Ictal wlth actual and proposed ea pond. Itures of the Bolev ecrool district. Thoy were tren by the prestdont of

For your ending June.

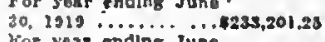
ror yesr ending juine $30,201,28$

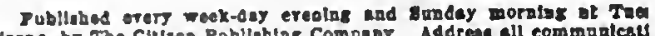
AMrops, by The Citisea Pabiloblag Compony. Addrea all combralcat

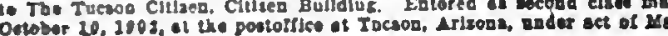
c. 1871 . Estlmate tor yoar end-

Moreover, it is rare to fin ders. The High School student relaxation. But the comparat inust not be inverted.

Nothing must be allowed for which High Schools and cs Dally. turee montha, ky mell. In adpnnce........

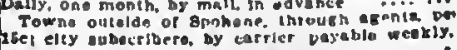
Weekly Chronlele. ale manthe in edvence. Spokane Can Not Afford

to Make Her Schools V Witu the defest of sh. at.hunl colle, $S_{1}$ chools sto facing a tenther inulue. For th 1922 term, accorcling (1) the irjurt of sch. bieials.

\section{LL HONOR TO NEAR CHAMPS.}

nocktord nover eent a teens to ths etulo bleb cheor

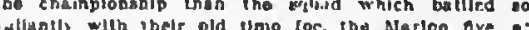

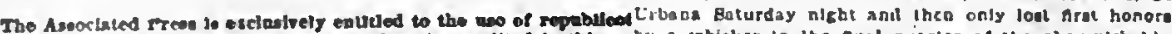
$x$ atl and also the lockl new a pobllehod berets.

\section{SUPPORT THE HIGH SCHOOL}

CIUPT. C T. ROSE of the Tueson schools, in today's Citi- ' zen, states definstely just what his views are as to the con-ont struction and uses of the proposed new high school for Tucson. the

In promising the readers of "llie Citizen on Thursday that such a statement would be submitted to them today, Ihough The Citizen by Mr. Rose, we said:

"Wic prophesy his state of mind In adrance of sam. day far enough to sumit that re espect it to be surb a vare act 9 cas

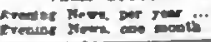

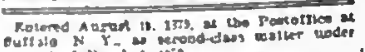

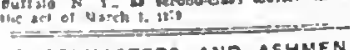
GCHOOLMASTERS AND ASHMEN, The counctl has iost no time in takTO SPEAK WELL.

Edocational devless, like almos verything clae, are a matter of dcrelopment. They do not come ato being full-grown; nor do they atrain 2 state of perlection overight There are devices that can lag full sdvanloge of the decision of be rejecled at obce because they the Court of Appeals in the Buffalo do nol meet the demands, and - thool case th घrent co fap at year there are othera which with a litle 1Elday's meeting. when the budgel rcadjustment may be mads 10 - as adopted, os to fix the eabries of, work with great cuccess. mployer of the departerent of edu Commiesioner Graves.

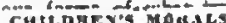

\section{CHitDEer's Mouscs.}

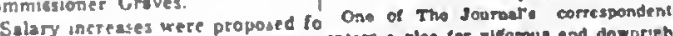

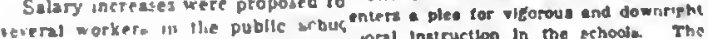

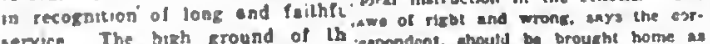

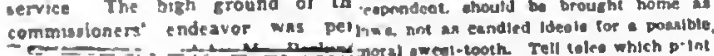

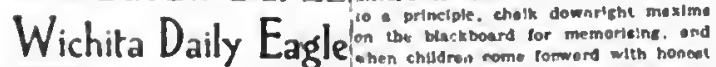

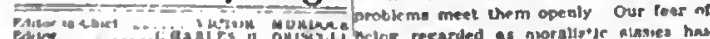

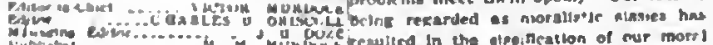

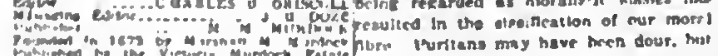
conser

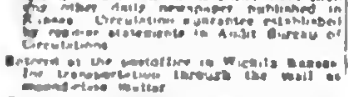

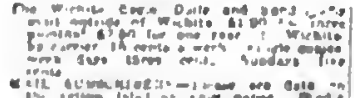

\section{FINISH IT}

The Roosetelt loteratediate acbool lurreat sod habdeoment of W'lchlte' putilic scbool bulldlage, ls about half Is whicker in the anal quinter of the champlohehlp

TEIE DAINY REPORTER MUST NOT LO White Plsine Oally Record and White Plelne Dally An Onisial clty and County Nowspaper

$$
\text { -THE- }
$$

White Plains Publishing Co. (INCOAPORATEO

Merlan Bidg., 148-150-152 Martine Avo. Telephene Entered os eecond-clase matter May 9, 1018, at the $f$ Offlee 21 White Pleina, N. Y,
Act of Mareh 3, 1879 .

\begin{tabular}{|c|c|}
\hline $\begin{array}{l}\text { W. Len Tuller } \\
\text { waiter V. Hogan }\end{array}$ & 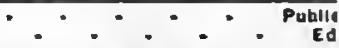 \\
\hline Ons Montn BUBSCR & IPTION RATES BY MALL Y Year- \\
\hline $\begin{array}{l}\text { Forelan Represente } \\
\cos \text { Ave., New Yo }\end{array}$ & 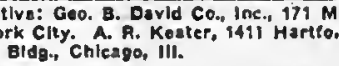 \\
\hline Whlle Plaine, & N. Y., Thuraday, February 24, 1921 \\
\hline
\end{tabular}

The people of this city are faced by a fact that needs to be met with serious consideration on every commonity. It the part of everyone It exists in the public more than ever esecnti boye and girls, when thi Accoriling to Superintendent of Schools work, should be helped I umbard there are now 1800 children on part selection of the work ime. More than one third the tolal of school hildren in the cily! Nearly one-half the boys There is in the lile and girls of White Plains receiving their educa vidual little elce that ta tion in a haphazard sort of wey, due to the fact portant theo the fiotin CUT SCHOOL EXPENSES LAST! 1ragedies of middle en

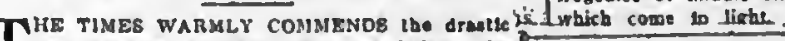
relredebmebl prosram advocalod befofo loo atale Hona yesterday by Bpeaker E. H. Oolool demade that thle/petrosebreal thell pot be al the expeave of tbe ectool cblldree of wablartob. Cut, by all means, ard lil orery posalble direction! The publlo domand vigorous etton. Tho noces-

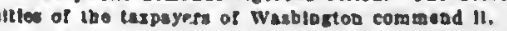
An Ms Odle ascalifeantly declared: "If lluto Re-l

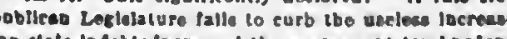

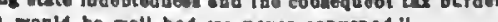
would be well bed we never cobveded."

\section{Intelle:}

HE chief defect. escess of loatrui but we do not as they are unelese in tbo itr is, but we do $20^{\circ}$. 


\section{CHAPTER III}

\section{SCHOOL NEWS FROM THE EDITOR'S VIEWPOINT}

\section{GENERAL STATEMENTS}

From a study of the material contained in Chapter III, the following conclusions have been drawn.

School items have real news value to the daily press.

School systems are cooperating to some extent with newspapers in the collection of school news.

A large amount of school news is being collected by newspapers independently of the school organization.

To a considerable extent, school reporters are furnishing school news to the newspapers.

The type of school news published in the daily newspaper is to some extent determined by the size of the city.

School pages and school columns are not common types of school news.

Special feature articles, high school notes, elementary school notes, and Parent-Teacher Association notes are the most common types of school news.

Public school athletic news is given undue emphasis in the daily press. itself.

The best type of school news is that which has news value in

School news should not in general be placed in departments. It should take "the run of the paper" and compete with other news for position.

In general, newspaper editors do not approve of charts and graphs in school news.

The use of illustrations in connection with school news is influenced in large newspapers by the amount of space available, and in small newspapers by the expense entailed.

Newspaper editors evidently desire the cooperation of school officials in the publication of school news. They believe in it and are willing to print more school news of the right sort.

In general, school people have not learned the technique of newspaper writing. They do not recognize the elements which make for news interest. Their writing style is not suited to the newspaper. They do not know how to prepare copy properly. They do not col- 
lect news systematically nor deliver it promptly. There is a very definite body of rules and suggestions for the proper preparation of newspaper copy.

The person responsible for preparing school news for the daily newspaper should adopt a friendly, cooperative, working basis with the newspaper organization. He should make himself familiar with the style and practices of the particular newspaper for which he is writing. He should perfect himself in the elements of news preparation as listed in the paragraph above.

Newspaper editors in general are without question interested in school news. They are sympathetic toward public school systems. They are willing to meet the school people more than half way in putting before the public information relative to the public schools.

The general summary and conclusions given above are based on the information submitted by 98 editors representing 40 different states.

\section{MATERIAL COLLECTED AND. METHOD USED}

How the

Editor's

Viewpoint

$W$ as Secured.

A question sheet was sent out to the editors of 200 daily newspapers. These newspapers represented every state in the Union, and were proportionately distributed among the three population groups mentioned in the previous chapter. Replies were received from 98 editors, approximately $50 \%$. The editors replying were located in 40 different states, and fairly represent all three population groups. A list of the newspapers cooperating is given in the Appendix, Table B. A large number of personal letters was received in connection with the returned question sheets. In practically every case the information given was signed by the editor himself.

A conscientious attempt has been made to report the opinions of the editors exactly as they were given. Wherever possible, their very words have been quoted. The cooperation and keen interest which the editors of these representative newspapers have shown in the subject of the study, have made it possible to present an authoritative body of fact and opinion, representing the thought of those who are responsible for the conduct of the daily paper.

The question sheet sent to the editors is reproduced as Form 3, page 37. From it the exact wording of the questions can be determined.

Note: All tables are numbered or lettered in such a way as to refer to that portion of the question sheet upon which they are based. For example, in Table III, the Roman numeral I at the left side of the table and tho Arabic numerals 1-2-3-4-5-6, at tho head of the columns, indicate that this table is based on tho Question Sheet sent to the Editors, questions $I, 1,2,3,4,5,6$. This method of designation will enable the reader, in the case of all tables, to identify the exact words in which the information tabulated was requested. 


\section{DETAILED FACTS AND CONCLUSIONS}

\section{Specific Conclusions Based on the Reports of 98 Editors}

1. The most common method used by newspapers in collect- How Newspapers ing school news is the assigning of a reporter to cover Collect

the school system. Table III, page 38 shows that School News.

$39 \%$ of the newspapers use this service daily, and that $19 \%$ use it irregularly. A larger percentage of newspapers in Group II use this method.

2. The second common method used by newspapers in collecting school news is the employing of paid student reporters. Table III shows that $17 \%$ of the newspapers use this service daily and that $32 \%$ use it irregularly or at intervals which were not specified. It is used most commonly by newspapers in cities of Group II.

3. The superintendent of schools is the third most important source of school news to the newspapers. Table III shows that $49 \%$ of the newspapers are furnished news by the superintendent of schools. In most cases this news is furnished irregularly. Newspapers in cities of Groups II and III more commonly receive news from the superintendent than those in cities of Group $I$.

4. Paid teacher reporters are very little used by newspapers. Table III shows that only $2 \%$ of the newspapers use this service.

5. Few newspapers employ an educational editor. Table III shows that only 10\% of all newspapers employ one. Most educational editors are found with newspapers in cities of Group I.

6. About half of all newspapers receive news from individual schools. Table III shows that $46 \%$ of the newspapers reporting get school news from this source. Practically all of it is furnished irregularly.

7. In most cases the newspaper depends upon definite reporters and paid student reporters for daily news service. Table III shows that only $3 \%$ of the newspapers get school news daily from the superintendent.

8. Newspapers evidently do not believe in collecting school news weekly or monthly. Table III plainly indicates this fact. 
The Types

of School News

Found in Daily

Nerwspapers.
9. Newspapers collect a large part of their school news irregularly. Table III shows that $19 \%$ of the newspapers assign reporters to school news irregularly and that $31 \%$ of the newspapers get school news from the superElintendent irregularly. The figures in Table III under the heading "Service Unspecified" should probably be included under "Irregularly".

10. About one half of the school systems are making little or no effort to furnish school news to the newspaper. Table III shows that $45 \%$ of the superintendents and that $46 \%$ of the individual schools furnish no school news to the newspaper.

II. The size of the city evidently has little effect upon the method of collecting school news, with the following exceptions: Newspapers in cities of Group I use the least number of student reporters. Newspapers in cities of Group I employ most of the educational editors.

\section{Specific Conclusions Based on the Reports of 98 Editors}

I. The school page is not a common type of school news. Table IV, page 39 shows that only I2\% of the newspapers use this type. Newspapers in cities of Group I use it most commonly.

2. The school column is not a common type of school news. Table IV shows that only $14 \%$ of the newspapers publish this type. The daily publication of the school column is most common in newspapers of cities in Group I. It is published in only $4 \%$ of all newspapers.

3. Special feature articles are used by about one half of the newspapers as a type of school news. This type is reported about equally often by newspapers in cities of all three groups. The most common practice is to publish these articles irregularly.

4. More newspapers report the use of high school notes than any other type of school news. Table IV shows that $70 \%$ of all newspapers publish this type of school news. The most common practice is to publish it daily or irregularly. Newspapers in cities of Group II lead in the daily publication of school notes. Newspapers in cities of Group III lead in the irregular publication of school notes. 
5. Elementary school notes are reported by about one half of the newspapers as a type of school news used. Table IV shows that the largest percentage of all newspapers publish this type irregularly. Newspapers in cities of Group II lead in the daily publication of elementary school notes. Newspapers in cities of Group III lead in the irregular publication of elementary school notes.

6. Public school athletic news is featured as a department by about one half of the newspapers. Table IV shows that newspapers in cities of the three groups vary little in the number of times which they report this type used.

7. Parent-Teacher Association notes are used by about onehalf of the newspapers as a type of school news. Table IV shows that newspapers in cities of the three groups vary little in the number of times they report this type of school news. The most common practice is to publish ParentTeacher Association notes daily or irregularly.

8. On the whole school news appears in the daily newspaper either daily or irregularly. Table IV shows that very. little school news is published weekly with the exception of the school page and high school notes, that practically no school news is published monthly, and that there is practically an equal division between daily publications and publication irregularly.

\section{Specific Conclusions Based on the Reports of 98 Editors}

I. The proper position of school news in the daily newspaper The Proper is wherever its news value warrants. In newspaper Position of parlance, it should take "the run of the paper".

School News in the Daily

2. In the opinion of newspaper editors, departments in the daily newspaper are undesirable and are fast going out Newspaper. of use.

From the replies received in answer to the question "What is the proper position of school news in the daily newspaper?" there is no doubt but that the majority of newspaper editors are unfavorable to special departments. Their arguments against such special departments are these: They are expensive to maintain; they interfere with the make up of the paper; and, last, they are not effective. So far as school news is concerned, the editors expressed the opinion that no one reads a school department in the newspaper unless he is already interested in the schools. As one editor expressed it: "You don't want to fish for those that you've already hooked". 
The Value of Illustrations to School News in the Daily Newspaper.
The Value

of Charts and Graphs 10

School News in the Daily Newspaper.
The editors were nearly unanimous in the opinion that school news should compete with all other news for space and position. If it is of first page news value, then it should go on the first page. On the other hand, to quote again, "If it is of no value, as is so often the case, it should go into the waste basket". The position of school news is presented in Table $V$, page 40 .

\section{Specific Conclusions Based on the Reports of 98. Editors}

I. Many editors believe that illustrations are of no value to school news. About one third of the editors of newspapers in cities of Groups I and II and about one half of the editors in Group III assign no value to illustrations.

2. The item of expense enters into the matter of illustrations. From the letters received it is evident that in the smaller cities of Group III the item of expense influences the opinion expressed as to the value of illustrations.

3. Some editors are of the opinion that the school system should furnish the cuts for illustrations.

4. The editors frequently stated that illustrations of persons or of action are much more valuable than illustrations of buildings, grounds, etc.

5. Probably the keen competition for space in large newspapers, and the item of expense in small newspapers, influence the prevailing opinion as shown in Table VI, page 40 that illustrations are of little or no value to school news in the daily newspaper.

\section{Specific Conclusions Based on the Reports of 98 Editors}

I. In general, newspaper editors do not believe that charts and graphs are of much value to school news in the daily newspaper. Table VII, page 4I shows that editors of newspapers in cities of the three groups agree very closely in this opinion. About $5 \%$ of the editors characterize charts and graphs as actually harmful to school news. Approximately $70 \%$ assign to them little or no value. About one-fourth of the editors consider that they have some value.

2. In letters received from the editors, the opinion was expressed that charts and graphs are adapted to specially trained readers, but that the average reader pays no attention to them. This opinion may be due to the 
kind of charts and graphs which have been submitted to newspapers. If, however, simple charts or graphs which contain the elements of the picture in them were used, perhaps they would appeal to the general newspaper reading public. The average newspaper editor has probably had little experience with this type of graphic representation. His very definite opinion, therefore, may be biased.

\section{Specific Conclusions Based on the Report of 98 Editors}

I. Newspapers would use more school news if it were furnished The Demand to them properly prepared. Table VIII, page 4 I for School News shows that $77 \%$ of the newspaper editors definitely by Daily stated that they would use more news of this sort. Newspapers. Only $6 \%$ submitted no answer.

2. Newspapers in cities of Groups II and III are evidently more desirous of school news than those in cities of Group I. This is plainly indicated in Table VIII. No doubt the stronger competition for space in newspapers of the larger cities causes less demand for school news.

3. In many of their letters, editors expressed regret that school systems were not cooperating with newspapers in furnishing school news to the public.

4. The majority of editors expressed their belief in the news value of school matters and in the desire of the newspaper reading public to get this kind of news.

5. Many editors expressed the opinion that only by intelligently informing the public of school matters through the daily press can school officials hope to get proper financial support for the public schools.

On the question sheet sent to the editors, they were asked, first, The Preparation to list some of the common faults of news copy furnished by school of School News people, and, secondly, to state five or six rules or suggestions which for the Daily will be of benefit to school people in preparing news for the press. Newspaper. The large number of replies received in answer to these questions, indicates the interest which the editors took in the study, and their willingness to assist in the problem of preparing school news for publication. The replies to both questions were carefully noted and classified together under certain main headings. As far as possible, the exact words of the editors have been quoted. This compilation needs no comment except to emphasize the fact that, coming from a large number of representative newspaper editors, it presents to the 
school administrator a body of rules and suggestions which will be of great value in the preparation of school news for the daily newspaper. The experience and newspaper practice which lie behind these rules and suggestions give to them unusual weight.

RULES AND SUGGESTIONS FOR THE PREPARATION OF SCHOOL NEWS IN DAILY NEWSPAPERS

From the Reports of 98 Newspaper Editors

III-2

Rules for

Preparing

School News.

I. SUBJECT MATTER.

(a) "Write news, not propaganda-news is something happening, an event of some sort, not an argument to prove or disprove some theory or proposition."

"Give information rather than advice or instruction."

(b) Be accurate, truthful, meticulously exact as to facts, names, and details.

(c) Write news for the public and not for the purpose of personal exploitation.

(d) Names have great news value.

"A story about an individual is always better than group facts."

(e) "Eliminate favoritism and personalities in preparing articles."

(f) "Eliminate inconsequential details, trivial happenings, commonplaces in general."

"Don't overemphasize nonessentials."

(g) "Run in a humorous phrase when it doesn't hurt anybody and when it does not spoil the text."

(h) "Make the story appeal to the average reader-more human stuff."

(i) "News should be written from the standpoint of the public, not from the standpoint of the school."

(j) "In general avoid submitting the achievements of precocious children unless the newspaper invites such contributions. Remember that every parent imagines his child to be a marvel."

(k) "Give the news about exceptional pupils, the latest experiments in education, and the like." 
2. NEWSPAPER STYLE.

(a) "Study the style of the newspaper and follow it."

"Make every contribution interesting by employing newspaper rather than literary diction."

"Write news, not literature."

School News.

(b) "Use news style as distinct from editorial style."

"Avoid the expression of opinion-merely recite what happened without interpreting what it means."

"Do not usurp editorial prerogatives by calling the attention of the public to school needs. Acquaint the editor with such needs and let him do the crusading."

"News is not editorial discussion."

"Give facts, not opinions."

"Get away from the academic."

"Get out of the idea of 'we' and 'our'."

(c) Use a simple style.

"Keep away from the technical and get down to simple terms."

"Avoid attempts at "fine writing."

"Use more American and less English."

"Be concise."

"Write clearly and to the point."

"Use short words instead of long ones."

"Avoid the use of too many adjectives."

"Use fewer capital letter."

"Don't be flamboyant."

"The public does not want 'fancy work' in news-just a simple statement of facts."

"Do not write in an ornate or didactic style-make it snappy."

(d) Be brief.

"Make it short."

"Make it brief and snappy."

"Don't use too many words to say little."

"Don't be verbose."

(e) "Get the main fact into the first paragraph."

"Get the gist of the story into the 'lead' and avoid mistaken headlines."

"Write the story in the first paragraph and let the details follow."

"State principal facts first."

(f) Avoid repetition. 
Rules for

Preparing

School News.

\section{NEWS SENSE AND NEWS INTEREST}

(a) "Develop a news sense and a sense for 'human interest' stories."

"Learn to spot 'news' when seen or heard."

"Learn what live news is and stick to it. The public can't be interested by long drawn out essays."

"It is the unusual that makes news."

"Realize the value of the news feature article."

"In writing news items, feature the unusual."

"Stress the strange, the odd, the unusual."

"Write about those things only which actually possess the elements of general interest."

"Learn to see the 'story' in the news."

"Regular routine matters do not interest readers."

"Keep the paper informed of all innovations."

\section{THE COLLECTION OF SCHOOL NEWS}

(a) "Establish a publicity department that will act as a clearing house for the school news of the entire system."

"Organize publicity within the school system and prevent much school news of interest from being lost."

"A press publicity department for schools in every city would be a grand institution."

(b) "Assign to one teacher in each school the collection and preparation of school news. Have it turned in to some central office where it will be available daily to the press."

"Make somebody in each school responsible for the news of that school."

"Have each room appoint a press agent."

"Have teachers direct the writing of school news by pupils and give them school credits for work produced."

"The Board of Education should make it compulsory for some one in each school to send daily to the newspaper or to the superintendent a news digest."

(c) "Engage a skilful newspaper photographer to supply pictures for school news."

(d) Collect news systematically-not hit or miss. 
(e) Cooperate with the newspaper organization.

Rules for

"Remember that the newspaper is willing to cooperate but expects cooperation."

Preparing School News.

"Remember that a newspaper must pay its way, and don't expect too much space."

"Don't suppress news just because it seems to reflect against the schools. Such action turns cooperation into a scrap between the editor and the school authorities for the news."

"Keep in close touch with editor and reporters. They will appreciate being called on the phone and told of anything that looks like news."

"Gauge your contribution by the size of the paper and the space allowed other public activities of a local nature."

"Welcome representatives of the press, deal with them frankly, and tell them the truth."

"Don't be backward about calling the attention of the press to the schools."

"Establish cordial relations with the press."

"Don't find fault and criticize when the editor finds it necessary to alter or change news."

"Keep in mind that newspapers have to be edited in the newspaper office."

"When school people acquire a liking for the aroma of printer's ink, school news will cease to be a fizzle and tax payers will stop kicking at school appropriations."

"Don't be partial to one newspaper in the community. Use them all alike."

5. THE DELIVERY OF SCHOOL NEWS.

(a) Get school news in on time.

"Deliver the news promptly."

"Give news as far in advance as possible."

"Announcements are worth more than reports both to school and newspaper."

"Get news in the day it happens if possible. Dailies like fresh stuff."

"Don't let news get cold."

"Don't let news become ancient history."

"News value depends largely upon recency of happening." 
Rules for

Preparing

School News. (b) The use of the phone for transmitting news tends toward inaccuracy.

6. THE MECHANICS OF SCHOOL NEWS COPY.

(a) "Use paper for copy $8 \frac{1}{2}$ by $6 \frac{1}{2}$ with lines running the long way. The size of the linotype keyboard determines this, not the whim of the editor."

(b) Use one side of the paper only.

(c) Typewrite all copy or write it clearly. "Submit clean copy."

(d) Double space or triple space your copy. This is a great benefit to the editor.

(e) Don't write the headline.

"Leave one third of your title page blank for the use of the newspaper headline writer."

"Headline writing is a technical newspaper function."

"Don't disgust the editor by writing the headline for him."

"Material for a headline should be found in the first paragraph or "lead' of copy."

(f) 'If a name is spelled in a peculiar manner, write 'correct' after it."

(g) "Use as few capitals as possible." 


\section{FORM 3.}

\section{QUESTION SHEET SENT TO NEWSPAPER EDITORS}

IMPORTANT-I have WORKED on This Form to make the ANSWERING OF IT AS LITTLE WORK FOR YOU AS TO YOU. POSSIBLE.

IMPORTANT - The answers to these questions should deal ONLY WITH THE SCHOOL NEWS OF YOUR LOCAL PUBTO ME LIC SCHOOL SYSTEM.

CITY. .STATE.

Please Answer By Checking In the Circles.

1. Do you assign DEFINITE REPORTERS to cover LOCAL SCHOOL NEWS?

2. Is there an EDUCATIONAL EDITOR ON THE STAFF of your Paper? . . . . . . . . . . . . . . . . . . . . .

3. Do you employ PAID LOCAL TEACHER REPORTERS

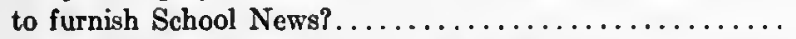

4. Do you employ PAID LOCAL STUDENT REPORTERS to furnish School News?.

5. Does the SUPERINTENDENT OF SCHOOLS furnish you PREPARED SCHOOL NEWS TO PUBLISH?.

6. Do INDIVIDUAL SCHOOLS furnish you PREPARED SCHOOL NEWS FOR PUBLICATION?...........

7. Would you use MORE SCHOOL NEWS IF IT WERE FURNISHED TO YOU PROPERLY PREPARED?....

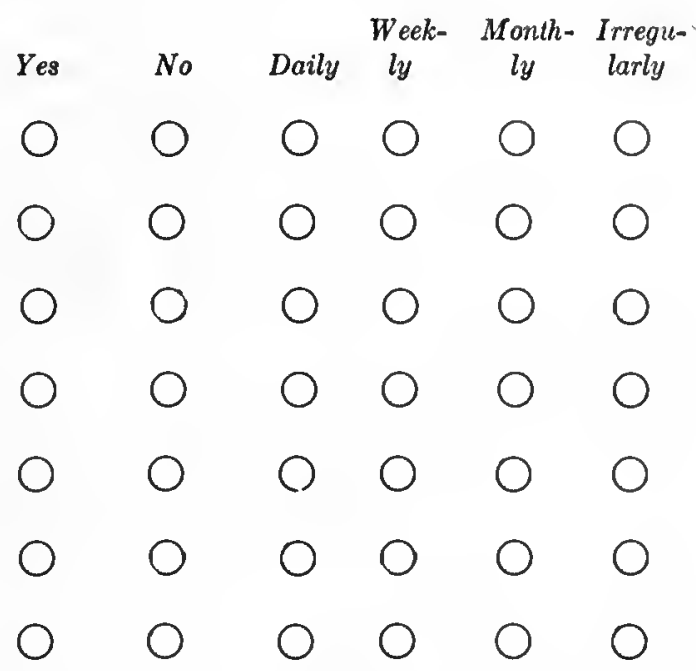

II. Please Check In The Squares The Departments Which Are Found In Your Paper.

1. A SCHOOL PAGE devoted mainly to the News of your LOCAL SCHOOL SYSTEM?

2. A SCHOOL COLUMN devoted mainly to the News of your LOCAL SCHOOL SYSTEM?..............

3. SPECIAL FEATURE NEWS ARTICLE dealing with some phase of the LOCAL SCHOOL SYSTEM?.......

4. Space devoted to LOCAL HIGH SCHOOL NOTES or NEWS?.

5. Space devoted to LOCAL ELEMENTARY SCHOOL NOTES or NEWS?........................

6. A DEPARTMENT devoted to LOCAL PUBLIC SCHOOL ATHLETICS?......................

7. SPACE DEVOTED to LOCAL PARENT-TEACHER

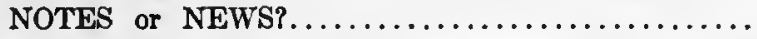

8. A PAGE, COLUMN or DEPARTMENT CONTRIBUTED by the SCHOOL CHILDREN OF THE SYSTEM?

9.

\begin{tabular}{|l|l|l|l|}
\hline Daily & Weekly & Monthly & Irregularly \\
\hline & & & \\
\hline & & & \\
\hline & & & \\
\hline & & & \\
\hline & & & \\
\hline & & & \\
\hline
\end{tabular}

III. Please answer the following questions ON THE BACK OF THIS SHEET.

1. List some of the MOST COMMON FAULTS of News Copy as furnished to you by School people.

2. State five or six rules or suggestions which, in your opinion, will be of benefit to School People in preparing School News for the Public Press.

3. Where, in your opinion, is the proper position of School News in your paper?

4. What, in your opinion, is the value of illustrations in Public School Publicity in Newspapers?

5. Do you think that CHARTS and GRAPHS if made SIMPLE help or harm Educational Articles in NEWSPAPERS? 
TABLE III.

HOW DAILY NEWSPAPER ORGANIZATIONS COLLECT SCHOOL NEWS FROM THE REPORTS OF 98 NEWSPAPER EDITORS

\begin{tabular}{|c|c|c|c|c|c|c|c|c|}
\hline \multirow{3}{*}{\multicolumn{2}{|c|}{ 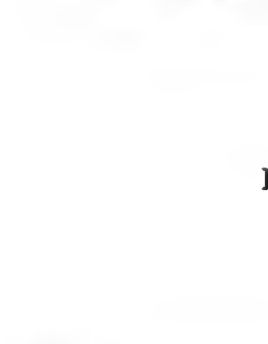 }} & & 1 & 2 & 3 & 4 & 5 & 6 \\
\hline & & & $\begin{array}{l}\text { Definite } \\
\text { Reporters } \\
\text { Cover } \\
\text { School } \\
\text { News }\end{array}$ & $\begin{array}{l}\text { Paper } \\
\text { Has } \\
\text { Educa- } \\
\text { tional } \\
\text { Editor }\end{array}$ & $\begin{array}{l}\text { Teacher } \\
\text { Reporters } \\
\text { Employed }\end{array}$ & $\begin{array}{l}\text { Student } \\
\text { Reporters } \\
\text { Employed }\end{array}$ & $\begin{array}{l}\text { Super- } \\
\text { intendent } \\
\text { Furnishes } \\
\text { School } \\
\text { News }\end{array}$ & $\begin{array}{l}\text { Indi- } \\
\text { vidual } \\
\text { Schools } \\
\text { Furnish } \\
\text { News }\end{array}$ \\
\hline & & & $\%$ & $\%$ & $\%$ & $\%$ & $\%$ & $\%$ \\
\hline \multicolumn{3}{|c|}{ 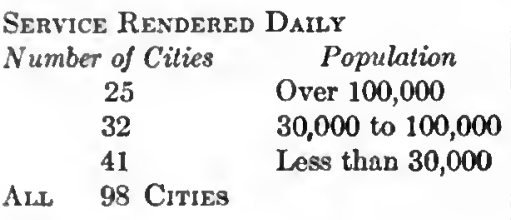 } & $\begin{array}{l}40 \\
50 \\
29 \\
39\end{array}$ & $\begin{array}{l}8 \\
3 \\
2 \\
4\end{array}$ & $\begin{array}{l}- \\
2 \\
1\end{array}$ & $\begin{array}{r}8 \\
31 \\
12 \\
17\end{array}$ & $\begin{array}{l}4 \\
3 \\
2 \\
3\end{array}$ & $\begin{array}{c}- \\
2 \\
1\end{array}$ \\
\hline \multicolumn{3}{|c|}{ 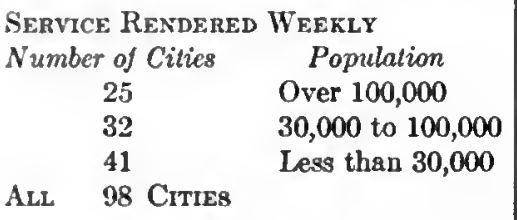 } & $\begin{array}{r}4 \\
3 \\
2\end{array}$ & $\begin{array}{l}- \\
- \\
-\end{array}$ & $\begin{array}{l}- \\
- \\
-\end{array}$ & $\begin{array}{l}- \\
- \\
-\end{array}$ & $\begin{array}{l}- \\
- \\
-\end{array}$ & $\begin{array}{l}- \\
3 \\
2 \\
2\end{array}$ \\
\hline \multicolumn{2}{|c|}{$\begin{array}{l}\text { Service ReNDERED } \\
\text { Number of Cuties } \\
25 \\
32 \\
41 \\
\text { ALL } \quad 98 \text { Citres }\end{array}$} & $\begin{array}{l}\text { Monthly } \\
\quad \text { Population } \\
\text { Over } 100,000 \\
30,000 \text { to } 100,000 \\
\text { Less than } 30,000\end{array}$ & $\begin{array}{l}- \\
- \\
-\end{array}$ & $\begin{array}{l}- \\
- \\
-\end{array}$ & $\begin{array}{l}- \\
- \\
-\end{array}$ & $\begin{array}{l}- \\
- \\
-\end{array}$ & $\begin{array}{c}- \\
2 \\
1\end{array}$ & $\begin{array}{c}- \\
\frac{2}{1}\end{array}$ \\
\hline \multicolumn{3}{|c|}{ 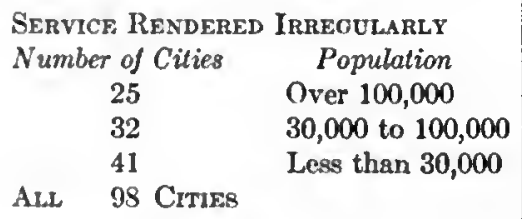 } & $\begin{array}{l}16 \\
12 \\
27 \\
19\end{array}$ & $\begin{array}{l}- \\
- \\
-\end{array}$ & $\begin{array}{l}- \\
- \\
-\end{array}$ & $\begin{array}{l}4 \\
6 \\
2 \\
4\end{array}$ & $\begin{array}{l}24 \\
38 \\
30 \\
31\end{array}$ & $\begin{array}{l}28 \\
41 \\
26 \\
32\end{array}$ \\
\hline \multicolumn{3}{|c|}{ 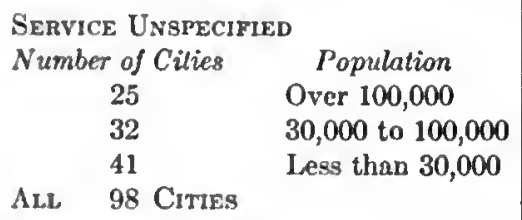 } & $\begin{array}{r}8 \\
13 \\
5 \\
8\end{array}$ & $\begin{array}{r}12 \\
3 \\
5 \\
6\end{array}$ & $\begin{array}{l}- \\
2 \\
1\end{array}$ & $\begin{array}{l}20 \\
25 \\
34 \\
28\end{array}$ & $\begin{array}{r}8 \\
9 \\
22 \\
14\end{array}$ & $\begin{array}{r}12 \\
3 \\
17 \\
11\end{array}$ \\
\hline \multicolumn{2}{|c|}{$\begin{array}{l}\text { Service Rendered } \\
\text { Number of Cities } \\
25 \\
32 \\
41 \\
\text { Al. } \quad 98 \text { Cities }\end{array}$} & $\begin{array}{l}\text { Not AT AlL } \\
\quad \text { Population } \\
\text { Over } 100,000 \\
30,000 \text { to } 100,000 \\
\text { Iess than } 30,000\end{array}$ & $\begin{array}{l}16 \\
19 \\
34 \\
25\end{array}$ & $\begin{array}{l}64 \\
94 \\
88 \\
84\end{array}$ & $\begin{array}{l}84 \\
94 \\
86 \\
88\end{array}$ & $\begin{array}{l}56 \\
38 \\
47 \\
40\end{array}$ & $\begin{array}{l}52 \\
47 \\
39 \\
45\end{array}$ & $\begin{array}{l}44 \\
50 \\
43 \\
46\end{array}$ \\
\hline $\begin{array}{l}\text { No A: } \\
\text { Numb }\end{array}$ & $\begin{array}{l}\text { Spwer Given } \\
\text { of of Cities } \\
25 \\
32 \\
41 \\
98 \text { Cities }\end{array}$ & $\begin{array}{l}\text { Population } \\
\text { Over } 100,000 \\
30,000 \text { to } 100,000 \\
\text { Less than } 30,000\end{array}$ & $\begin{array}{r}16 \\
3 \\
5 \\
7\end{array}$ & $\begin{array}{c}10 \\
5 \\
6\end{array}$ & $\begin{array}{r}16 \\
6 \\
10 \\
10\end{array}$ & $\frac{12}{5}$ & $\begin{array}{r}12 \\
3 \\
5 \\
6\end{array}$ & $\begin{array}{r}16 \\
3 \\
5 \\
7\end{array}$ \\
\hline
\end{tabular}

Read the table as follows: Of 25 newspapers in eities over 100,000 in population, $40 \%$ assign definite reporters to cover chool news daily; $8 \%$ have the service of an educational editor daily; etc. 
TABLE IV.

TYPES OF SCHOOL NEWS FOUND IN DAILY NEWSPAPERS FROM THE REPORTS OF 98 NEWSPAPER EDITORS

\begin{tabular}{|c|c|c|c|c|c|c|c|c|c|c|}
\hline \multirow{3}{*}{\multicolumn{2}{|c|}{ I }} & \multirow{3}{*}{ II } & 1 & 2 & 3 & 4 & 5 & 6 & 7 & 8 \\
\hline & & & $\begin{array}{c}\text { School } \\
\text { Page }\end{array}$ & $\begin{array}{l}\text { School } \\
\text { Column }\end{array}$ & $\begin{array}{l}\text { Special } \\
\text { Feature } \\
\text { Articles }\end{array}$ & $\begin{array}{c}\text { High } \\
\text { School } \\
\text { Notes }\end{array}$ & $\begin{array}{l}\text { Elem- } \\
\text { entary } \\
\text { School } \\
\text { Notes }\end{array}$ & $\begin{array}{l}\text { Ath- } \\
\text { letic } \\
\text { De- } \\
\text { part- } \\
\text { ment }\end{array}$ & $\begin{array}{l}\text { Parent- } \\
\text { Teacher } \\
\text { Associ- } \\
\text { ation }\end{array}$ & $\begin{array}{l}\text { Page or } \\
\text { Column } \\
\text { Contrib- } \\
\text { uted by } \\
\text { Children }\end{array}$ \\
\hline & & & $\%$ & $\%$ & $\%$ & $\%$ & $\%$ & $\%$ & $\%$ & $\%$ \\
\hline \multicolumn{3}{|c|}{ 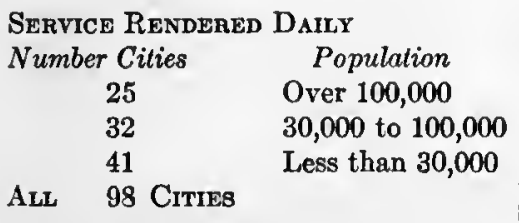 } & $\begin{array}{c}- \\
- \\
-\end{array}$ & $\begin{array}{l}8 \\
3 \\
2 \\
4\end{array}$ & $\begin{array}{r}8 \\
9 \\
-5\end{array}$ & $\begin{array}{l}12 \\
47 \\
20 \\
26\end{array}$ & $\begin{array}{r}12 \\
22 \\
5 \\
12\end{array}$ & $\begin{array}{l}16 \\
38 \\
12 \\
22\end{array}$ & $\begin{array}{l}24 \\
38 \\
12 \\
24\end{array}$ & $\frac{4}{-}$ \\
\hline \multicolumn{3}{|c|}{ 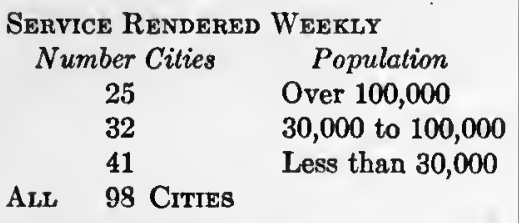 } & $\begin{array}{r}20 \\
6 \\
2 \\
8\end{array}$ & $\frac{4}{7}$ & $\begin{array}{l}-\overline{3} \\
2 \\
2\end{array}$ & $\begin{array}{r}12 \\
3 \\
15 \\
10\end{array}$ & $\begin{array}{c}8 \\
3 \\
3\end{array}$ & $\begin{array}{c}- \\
2 \\
1\end{array}$ & $\begin{array}{c}8 \\
2 \\
3\end{array}$ & $\begin{array}{c}8 \\
2 \\
3\end{array}$ \\
\hline \multicolumn{3}{|c|}{ 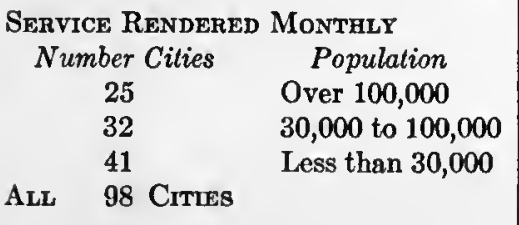 } & $\begin{array}{l}- \\
- \\
-\end{array}$ & $\begin{array}{l}- \\
- \\
-\end{array}$ & $\begin{array}{l}- \\
- \\
-\end{array}$ & $\begin{array}{l}- \\
- \\
-\end{array}$ & $\begin{array}{l}- \\
- \\
-\end{array}$ & $\begin{array}{l}- \\
- \\
-\end{array}$ & $\begin{array}{c}- \\
5 \\
2\end{array}$ & $\begin{array}{l}- \\
- \\
-\end{array}$ \\
\hline \multicolumn{3}{|c|}{ 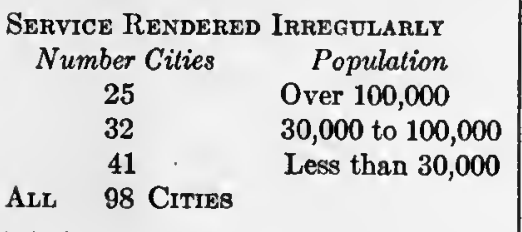 } & $\begin{array}{c}4 \\
7 \\
4\end{array}$ & $\begin{array}{l}- \\
6 \\
9 \\
6\end{array}$ & $\begin{array}{l}36 \\
41 \\
47 \\
42\end{array}$ & $\begin{array}{l}24 \\
16 \\
44 \\
30\end{array}$ & $\begin{array}{l}16 \\
18 \\
36 \\
26\end{array}$ & $\begin{array}{l}\frac{20}{30} \\
17\end{array}$ & $\begin{array}{l}24 \\
12 \\
30 \\
22\end{array}$ & $\begin{array}{c}- \\
9 \\
2 \\
4\end{array}$ \\
\hline \multicolumn{3}{|c|}{ 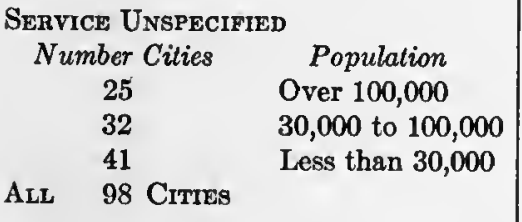 } & $\begin{array}{l}- \\
- \\
-\end{array}$ & $\begin{array}{l}- \\
- \\
-\end{array}$ & $\begin{array}{l}- \\
- \\
-\end{array}$ & $\begin{array}{l}4 \\
6 \\
2 \\
4\end{array}$ & $\begin{array}{l}4 \\
9 \\
5 \\
6\end{array}$ & $\begin{array}{r}16 \\
32 \\
5 \\
13\end{array}$ & $\begin{array}{r}4 \\
13 \\
2 \\
6\end{array}$ & $\begin{array}{l}- \\
- \\
-\end{array}$ \\
\hline $\begin{array}{r}\text { Servi } \\
N u\end{array}$ & $\begin{array}{l}\text { Ce Rendered } \\
\text { nber Cities } \\
25 \\
32 \\
41 \\
98 \text { Citres }\end{array}$ & $\begin{array}{l}\text { Not At Ali } \\
\text { Population } \\
\text { Over } 100,000 \\
30,000 \text { to } 100,000 \\
\text { Less than } 30,000\end{array}$ & $\begin{array}{r}16 \\
6 \\
10 \\
10\end{array}$ & $\begin{array}{r}16 \\
3 \\
7 \\
8\end{array}$ & $\begin{array}{c}8 \\
2 \\
3\end{array}$ & $\frac{8}{-}$ & $\frac{4}{-}$ & $\begin{array}{c}8 \\
2 \\
3\end{array}$ & $\begin{array}{r}4 \\
3 \\
-\end{array}$ & $\begin{array}{r}12 \\
6 \\
7 \\
8\end{array}$ \\
\hline \multicolumn{3}{|c|}{\begin{tabular}{cl} 
No ANswer Grven & \\
Number Cities & \multicolumn{1}{c}{ Population } \\
25 & Over 100,000 \\
32 & 30,000 to 100,000 \\
41 & Less than 30,000 \\
ArL 98 Ciries & \\
\end{tabular}} & $\begin{array}{l}60 \\
88 \\
81 \\
78 \\
\end{array}$ & $\begin{array}{l}72 \\
88 \\
74 \\
78\end{array}$ & $\begin{array}{l}48 \\
47 \\
49 \\
48\end{array}$ & $\begin{array}{l}40 \\
28 \\
19 \\
28\end{array}$ & $\begin{array}{l}56 \\
47 \\
54 \\
52\end{array}$ & $\begin{array}{l}40 \\
40 \\
49 \\
44 \\
\end{array}$ & $\begin{array}{l}36 \\
34 \\
49 \\
41 \\
\end{array}$ & $\begin{array}{l}76 \\
85 \\
88 \\
84 \\
\end{array}$ \\
\hline
\end{tabular}

Read the table as follows: Of 25 newspapers in cities of 100,000 and over, $8 \%$ publish a school column daily; $8 \%$ publish special feature articles daily; etc. 
TABLE V.

THE PROPER POSITION OF SCHOOL NEWS IN THE DAILY NEWSPAPER FROM THE REPORTS OF 98 NEWSPAPER EDITORS

\begin{tabular}{c|c|c|c|c|c|c}
\hline \multicolumn{2}{c|}{ III-3 } & $\begin{array}{c}\text { Run of } \\
\text { Paper }\end{array}$ & $\begin{array}{c}\text { Fixed } \\
\text { Position }\end{array}$ & $\begin{array}{c}\text { Regular } \\
\text { Department }\end{array}$ & Unceriain & $\begin{array}{c}\text { No } \\
\text { Answer }\end{array}$ \\
\hline Number of Cities & Population & $\%$ & $\%$ & $\%$ & $\%$ \\
\hline 25 & Over 10,0000 & 60 & 4 & 4 & 4 & 28 \\
32 & 30,000 to 100,000 & 72 & -34 & 3 & 22 \\
41 & Less than 30,000 & 34 & 10 & 8 & 3 & 3 \\
\hline ALL 9S Citres
\end{tabular}

Read the table as follows: Of 25 newspaper editors in cities of 100,000 and over, $60 \%$ report that the proper position for school news is the "run of the paper"; $4 \%$, that school news should have some fixed position; $4 \%$, that school news should be placed in a regular school department, etc.

TABLE VI.

THE VALUE OF ILLUSTRATIONS TO SCHOOL NEWS IN THE DAILY NEWSPAPER FROM THE REPORTS OF 98 NEWSPAPER EDITORS

\begin{tabular}{|c|c|c|c|c|c|c|}
\hline \multicolumn{2}{|c|}{ III-4 } & $\begin{array}{c}\text { Of Great } \\
\text { Value }\end{array}$ & $\begin{array}{c}\text { Of Some } \\
\text { Value }\end{array}$ & $\begin{array}{l}\text { Of Little } \\
\text { Value }\end{array}$ & $\begin{array}{l}\text { Of No } \\
\text { Value }\end{array}$ & $\begin{array}{c}\text { Too } \\
\text { Expensive }\end{array}$ \\
\hline Number of Cuites & Population & $\%$ & $\%$ & $\%$ & $\%$ & $\%$ \\
\hline $\begin{array}{l}25 \\
32 \\
41\end{array}$ & $\begin{array}{l}\text { Over } 100,000 \\
30,000 \text { to } 100,000 \\
\text { Less than } 30,000\end{array}$ & $\begin{array}{r}28 \\
28 \\
5\end{array}$ & $\begin{array}{l}36 \\
41 \\
29\end{array}$ & $\begin{array}{l}4 \\
3 \\
2\end{array}$ & $\begin{array}{l}32 \\
28 \\
54\end{array}$ & $\frac{-}{10}$ \\
\hline Alz 98 Citieg & & 18 & 35 & 3 & 40 & 4 \\
\hline
\end{tabular}

Read the table as follows: Of 25 newspaper editors in cities of 100,000 population and over, $28 \%$ consider illustrations of great value to school news; $36 \%$ consider illustrations of some value; etc. 
TABLE VII.

THE VALUE OF CHARTS AND GRAPHS TO SCHOOL NEWS IN THE DAILY NEWSPAPER

FROM THE REPORTS OF 98 NEWSPAPER EDITORS

\begin{tabular}{|c|c|c|c|c|c|c|}
\hline \multicolumn{2}{|c|}{ III -5} & $\begin{array}{l}\text { Of Some } \\
\text { Value }\end{array}$ & $\begin{array}{l}\text { Of Little } \\
\text { Value }\end{array}$ & $\begin{array}{c}\text { Of Questionable } \\
\text { Value }\end{array}$ & $\begin{array}{l}\text { Of No } \\
\text { Value }\end{array}$ & Harmful \\
\hline Number of Cities & Population & $\%$ & $\%$ & $\%$ & $\%$ & $\%$ \\
\hline $\begin{array}{l}25 \\
32 \\
41\end{array}$ & $\begin{array}{l}\text { Over } 100,000 \\
30,000 \text { to } 100,000 \\
\text { Less than } 30,000\end{array}$ & $\begin{array}{l}24 \\
25 \\
27\end{array}$ & $\begin{array}{r}8 \\
6 \\
-\end{array}$ & $\begin{array}{r}4 \\
10 \\
7\end{array}$ & $\begin{array}{l}64 \\
56 \\
56\end{array}$ & $\begin{array}{r}- \\
3 \\
10\end{array}$ \\
\hline ALl 98 CrTies & & 26 & 4 & 7 & 58 & 5 \\
\hline
\end{tabular}

Read the table as follows: Of 25 newspaper editors in cities of 100,000 and over, $24 \%$ consider charts and graphs of some value to school news; $8 \%$ consider charts and graphs of little value; etc.

TABLE VIII.

THE DEMAND FOR SCHOOL NEWS BY DAILY NEWSPAPERS

FROM THE REPORTS OF 98 NEWSPAPER EDITORS

\begin{tabular}{|c|c|c|c|c|c|}
\hline \multicolumn{2}{|c|}{$I-7$} & Yes & No & Questionable & No Answer \\
\hline Number of Cities & Population & $\%$ & $\%$ & $\%$ & $\%$ \\
\hline $\begin{array}{l}25 \\
32 \\
41\end{array}$ & $\begin{array}{l}\text { Over } 100,000 \\
30,000 \text { to } 100,000 \\
\text { Less than } 30,000\end{array}$ & $\begin{array}{l}64 \\
81 \\
80\end{array}$ & $\begin{array}{l}20 \\
13 \\
15\end{array}$ & $\frac{4}{2}$ & $\begin{array}{r}12 \\
6 \\
2\end{array}$ \\
\hline ALL $\quad 98$ CrTIES & & 77 & 15 & 2 & 6 \\
\hline
\end{tabular}

Read the table as follows: Of 25 newspaper editors in cities of 100,000 and over, $64 \%$ would use more school news if furnished to them properly prepared; $20 \%$ would not; $4 \%$ are not sure; and $12 \%$ gave no answer. 


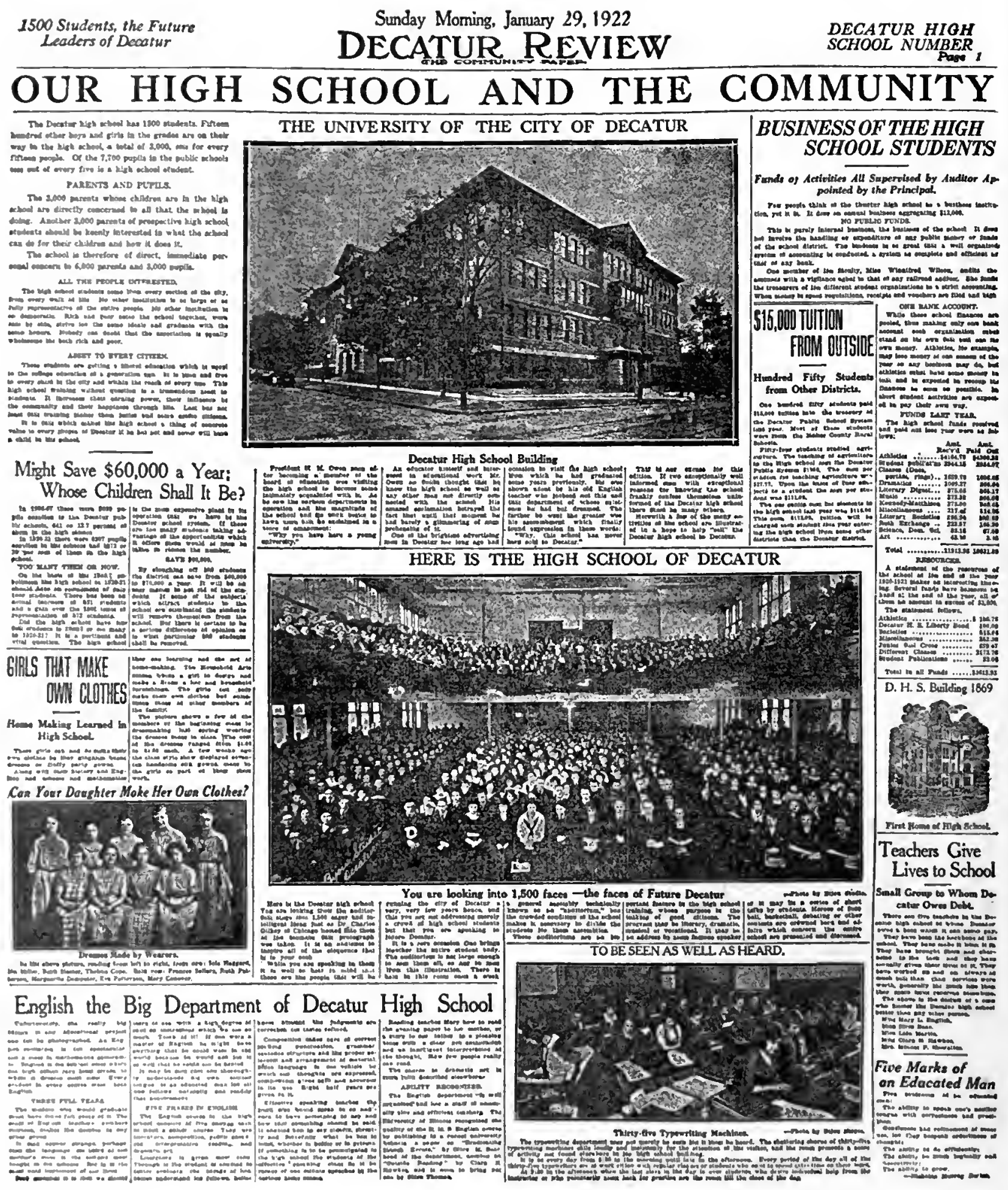

A HIGH SCHOOI, NUMBER OF A DAILY NEIVSPAPER 


\section{CHAPTER IV}

\section{SCHOOL NEWS FROM THE SUPERINTENDENT'S VIEWPOINT}

\section{GENERAL STATEMENTS}

From a study of the material contained in Chapter IV, the following conclusions have been drawn.

Most school systems have effected no organization for educational publicity.

Few systems in their annual budgets provide for school publicity, and on the whole little money is spent for this purpose.

The majority of superintendents are not willing to state an opinion relative to the percentage of the school budget which should be set aside for publicity. The percentage recommended varies from $3 \%$ of the budget to nothing. In general, superintendents in the smaller cities recommend that a higher percentage of the budget should be spent for publicity than do those in the larger cities.

About one fourth of the school systems have some centralized agency for handling school news.

The majority of school superintendents furnish school news to the newspapers. About one half of the high school and elementary school principals furnish school news. Individual students and students in English and journalism classes are furnishing a considerable amount of news to the newspapers.

The most common practice is for school systems to furnish news irregularly to the newspapers.

Most school news is edited and approved. by, principals. In about one third of the school systems, the news collected is approved and edited by some central office. Athletic news is almost entirely edited by the athletic coach.

Newspapers depend first upon definitely assigned reporters for the securing of school news, second upon superintendents, third upon paid student reporters, and fourth upon individual schools.

Evidently a large percentage of school systems have little or no relations with newspapers so far as furnishing school news is concerned.

A large majority of newspapers are favorable in their attitude toward the public school system. Editors believe in school news, discuss it in their editorial columns, are willing to cooperate with 
school superintendents, and express a willingness to use more school news of the right sort.

School systems have carried on a large number of continuous campaigns in the daily papers. The five most commonly reported are, campaigns for buildings, campaigns for teachers' salaries, health campaigns, bond issue campaigns, and night school campaigns.

There is a definite belief on the part of superintendents that the afternoon and evening edition of the newspaper is the best for carrying school news.

In general, school superintendents believe that there are valid reasons for expending public funds on school publicity. They recognize the difficulty of being charged with partiality in giving out school news, and in many cases have evolved ways of overcoming this difficulty. They are almost unanimous in the opinion that the attitude of the daily press toward the school system is extremely important, and that the use of the daily press by school administrators should be governed by definite ethical principles.

Newspaper organizations do not always handle school news properly. In many cases they lack the school point of view. Their sense of news value often results in emphasis wrongly placed or sensational presentation. They are not always careful to present the facts exactly as they exist. They sometimes allow political reasons to color school news. As a general thing, they do not give to news of the public school system the attention and position to which its importance entitles it.

\section{MATERIAL COLLECTED AND METHOD USED}

How the

Superintendent's

Viewpoint

Was Secured.
A question sheet was sent to 500 superintendents of schools in cities of each of the three population groups mentioned in previous chapters. The replies from 250 , exactly $50 \%$ of these superintendents, representing 45 states, and distributed proportionately among the three city groups, furnished the material for the tables in this chapter, upon which the conclusions are based. A list of the superintendents cooperating will be found in Appendix, Table C. Great care has been used in reporting the opinions of the superintendents and, as in the case of the newspaper editors, the exact words have been quoted wherever possible. Most of the information contained in the tables is expressed in percents computed to the nearest whole percent, for purposes of comparison. The cooperation of superintendents has made possible the presentation of the facts in this chap- 
ter. Their interest in the subject of school news is evidenced by their generous responses.

The question sheet sent to the superintendents is reproduced as Form 4, page 62 in order that the exact wording of the questions asked may be ascertained.

\section{DETAILED FACTS AND CONCLUSIONS}

\section{Specific Conclusions Based on the Report of 250 Superintendents}

I. Few city school systems contain specific provision in their Financing budgets for information or publicity service. Table School IX, page 66 shows that only $8 \%$ of all school systems Information make such provision. From the reports received, it Service. is impossible to give any estimate in dollars of this provision.

2. A much larger number of city school systems have funds which can be used for information or publicity service. Table IX shows that $39 \%$ of all school systems have such a fund. School systems in cities of Group III lead in this particular with $48 \%$. From the reports received, it is impossible to give a definite measure of the amount used from these funds for publicity, but it can safely be stated that the amount is uniformly small.

3. There is considerable variation in the opinion of superintendents as to the percentage of the budget which should be spent for school information service. Table $X$, page 66 shows that this percentage ranges from $3 \%$ to $0 \%$. A majority of the superintendents in cities of Group I and Group II gave no answer. Over one half of the superintendents in cities of Group III stated an opinion. Approximately three fourths of the superintendents giving an opinion believe that some percentage of the budget should be spent for publicity. One fourth of the superintendents report that in their opinion no part of the budget should be spent for this service. In general, superintendents in cities of Group III recommend a larger proportion of the budget for information service.

The detailed reports substantiating conclusions just stated are given in Tables IX and X, page 66. 
How School

Systems

Collect News

for Newspapers.
Specific Conclusions Based on the Reports of 250

\section{SupERINTENDENTS}

I. Some city school systems have made provisions for a news service organization. Table XI, page 66 shows that in $28 \%$ of the school systems there is a person responsible for the collecting and releasing of school news. Table $\mathrm{XI}$ also shows that in $\mathrm{I} 2 \%$ of the cities there is a news service committee for the entire school system.

2. School systems in the three population groups do not vary much in reference to news service organization.

3. Various means for collecting school news are utilized by city school systems. Table XII, page 67 shows that in $79 \%$ of the cities, the superintendents collect school news; in $61 \%$, the high school principals; in $48 \%$, elementary school principals; in $37 \%$, supervisors; in $37 \%$, clerks of the school boards; in $35 \%$, individual students; in $26 \%$, individual teachers; in $24 \%$, English classes; in $13 \%$, journalism classes; and in $5 \%$, news editors.

4. The largest percentage of school systems collect school news irregularly; a second common practice of school systems is to collect news daily; some school systems collect school news weekly, and a negligible percent collect news monthly. It is of interest to note, from Table XII, that about one fourth of the superintendents of schools collect school news daily. It is also significant to note that in $35 \%$ of the school systems individual students collect news; in $24 \%$, English classes collect news; and in $13 \%$, journalism classes. Most of this student service is rendered either daily or weekly.

The detailed reports of superintendents in reference to the organization and collection of school news will be found in Tables XI and XII, pages 66 and 67.

\section{Specific Conclusions Based on tie Reports of 250 Superintendents}

I. In one third of all school systems, school news collected within the system comes to a central office for editing and approval before being released.

Table XIII, page 68 shows that this practice is most common in cities of Group III.
Horo School News

Is Approoed

and Edited

by School

Sysiems. 
2. Most of the editing and approving of school news is done by school principals.

3. A considerable amount of the editing and approving of school news is done by persons not within the school system. The amount of this editing is indicated in Table XIV, page 69 opposite the heading, "Edited by Others". Through an error in the question sheet, a large part of these "others" consists of superintendents of schools. From the information received, it was not possible to separate the superintendents included in this group.

4. School athletic news is almost entirely edited and approved by athletic coaches. Table XIV shows that this practice is common to cities of each of the three groups.

5. School systems in cities of Group II and Group III make the most provision for the editing and approving of school news by individuals within the system.

6. News of school athletics and high school notes most commonly receive editing and approval from within the school system. Table XIV shows that $50 \%$ of the school systems edit athletic news and that $48 \%$ edit high school notes.

7. The editing and approval of school news by student editors and classes is worthy of notice. Table XIV shows that to some extent editorial responsibility rests with students.

The detailed reports of school systems relative to the editing and approval of school news will be found in Tables XIII and XIV, pages 68 and 69.

\section{Specific Conclusions Based on the Reports of 250 SUPERINTENDENTS}

I. Definitcly assigned reporters and superintendents are most The Relations commonly used by newspapers for securing school of Public news. Table XV, page 70 shows that in $71 \%$ of the School Systems school systems definite reporters cover school news, and with Local that $40 \%$ of this service is rendered daily. Table XV Newspaper also shows that in $83 \%$ of the school systems superin- Organizations. tendents furnish school news and that $4 \mathrm{I} \%$ of this service is given irregularly. 
2. Paid student reporters are employed to furnish school news in about one fourth of the school systems. Table XV shows that the percentage is 24 and that more than one half of this service is rendered daily.

3. Paid teacher reporters are very seldom employed to furnish school news. Table XV shows that in less than $2 \%$ of the school systems this service is employed.

4. Few newspapers employ an educational editor. Table XVI, page 71 indicates about $7 \%$. By far the larger number of these are in the cities of Group I.

5. In about one half of the school systems, individual schools furnish school news to the newspapers. Table XV shows that most of this service is irregular.

6. The most common practice is for newspapers to secure school news service daily or irregularly. Very little service is rendered weekly, and practically none monthly.

7. A large percent of school systems have no relations with the newspapers so far as furnishing news is concerned.

8. Editors and superintendents do not agree in their statements relative to the collecting and furnishing of school news. This is evident from a comparison of Tables III, page 38 and XV. No doubt the editors are inclined to underestimate the part which the school system plays in furnishing news, and no doubt the superintendents are inclined to overestimate it.

The detailed facts relative to the relations between the school systems and newspaper organizations will be found in Tables XV and XVI, pages 70 and 71 .

Departments in Newspapers Devoted to School News

\section{Specific Conclusions Based on the Reports of 250 SUPERINTENDENTS}

I. The school department most often reported as appearing in the daily newspaper is that devoted to school board meeting news. Table XVII, page 72 shows that the most common practice is to present this news irregularly.

2. Editors and superintendents agree very closely in reference to the types of school departments which appear in the daily newspaper and the commonness and frequency with which they are found. In general, all the conclusions drawn from Table IV, page 39 and discussed in Chapter III can be drawn from Table XVII. 
The detailed facts submitted by superintendents relative to the departments in daily newspapers devoted to school news will be found in Table XVII, page 72.

\section{Specific Conclusions Based on the Reports of 250 SUPERINTENDENTS}

I. From the statements of superintendents, the attitude of the The Attitude of daily newspapers toward public school systems is dis- Daily Newspapers tinctly favorable. Table XVIII page 73 shows that of toward Public 627 different daily newspapers reported on by 219 School Systems. superintendents, $39 \%$ gave the school system active support, $43 \%$ gave it friendly cooperation, and only $8 \%$ were unfavorable or hostile.

2. School news is very often the subject matter of newspaper editorials. Table XVIII shows that in 250 school systems, $2 \mathrm{r} \%$ of the newspapers discussed school matters frequently in the editorials; $54 \%$ occasionally; and only $13 \%$ seldom or never. It is of interest to compare this statement with the $5 \%$ of editorials dealing with local school matters which were found in the number count of 1800 newspapers as set forth in Table I, page 21 . It is also of interest to recall that of the 98 editors reporting in Table VIII, page $4 \mathbf{I} 77 \%$ stated that they would use more school news if furnished properly prepared.

3. In general, it may be stated that newspaper organizations believe in school news, that they have the right attitude toward the school system, and are anxious to cooperate with school systems in putting news of the public schools before the public.

The tabulated opinion of superintendents of schools relative to the attitude of daily newspapers toward the public school system and the amount of discussion which is given to school matters in editorials, will be found in Tables XVIII and XIX, page 73 .

\section{A BODY OF OPINION BASED ON THE REPORTS OF $25^{\circ}$ SUPERINTENDENTS}

There is clearly a variety of information in any school system Continuous which can be made the subject of newspaper campaigns. Publicity These matters are vital to the school system and will be of Campaigns interest to newspaper readers if properly presented. In order to Carried on learn the variety of subjects which school superintendents have in the Daily brought to the attention of the public through newspaper campaigns, Newspaper. the question sheet asked for information in this particular.

Twenty-eight different types of publicity campaigns were reported. The first ten in order of the frequency with which they were 
The Best Edition of Newspapers For Carrying School News.
Valid Reasons for Expending Public Funds to Publish School News. reported by the superintendents are as follows: Building Campaign, Better Salaries Campaign, Health Campaign, Bond Issue Campaign, Night School Campaign, Thrift Campaign, School Week Campaign, Americanization Campaign, Attendance Campaign, Safety First Campaign. Of these ten campaigns carried on in the daily papers, only three can be considered as special purpose or emergency campaigns, namely, Buildings, Salaries, and Bonds. The other seven we may designate as continuous campaigns, in that the object of the publicity is not necessarily to achieve some immediate purpose once and for all, but rather to carry to the people those things in the public school system which are constant and continuous, year after year. This type of newspaper campaign is the one for which the superintendent of schools needs to plan a program, and it is a type of publicity which is as important as the special purpose publicity relating to the raising of bond issues, and the like. Such campaigns, together with the incidental, everyday news and information concerning the school system, should comprise the bulk of a publicity program for the public schools.

The frequency with which school systems have carried on these campaigns in the daily newspaper is set forth in Table XX, page 74 .

The remaining material in this chapter consists of the opinons of superintendents of schools, relative to various general matters which are closely connected with the use of the daily newspaper as a means of school publicity.

Three newspaper editions are published in many cities, a morning, an afternoon and evening, and a Sunday edition. Superintendents were asked on the question sheet to rank these three editions in order of their effectiveness in getting school news to the community. Only the rankings of those superintendents in cities having all three cditions were considered. The tabulation of these rankings in Table $\mathrm{XXI}$, page 75 shows that the afternoon and evening edition is very definitely considered most effective for carrying school news. The Sunday edition is next effective, and the morning edition least effective. The general feeling that evening and Sunday editions are "Home Editions" no doubt partly accounts for this opinion.

Are there valid reasons for the expenditure of public funds on publicity for school systems? The answer to this question is important, and the opinion of superintendents in regard to it are valuable. The question does not refer exclusively to the use of the daily paper, but rather to the whole program of public school information service in which the newspaper is an important element.

From the statements of editors considered in Chapter III, it is clear that a great deal of school news is being printed by the daily 
papers without cost to the school system. In so far as it is good "news", the newspapers are evidently not only willing to print it free of charge but anxious to get more of it. On the other hand, there are types of school publicity which, in the opinion of superintendents, are desirable for publication, but which do not have enough "news" interest to warrant the furnishings of free space on the part of the newspaper. It is desirable at times to print pure display advertising in the interests of the school system. In so far, therefore, as it is advisable to print this non-news material, the expense of newspaper publication enters into the question of expending public funds for publicity purposes. In answering the question, however, superintendents no doubt had the whole publicity program in mind, including all printed material which gives information about the school system. Representative answers to this question received from superintendents are found in the compilation of opinion which follows.

The majority of superintendents evidently believe that there are valid reasons for expending public funds for publicity purposes. Their reasons as expressed are the following:

I. The effect which such expenditure will have upon the finan- Principal cial support of the school-the giving of information Reasons for for the purpose of securing financial support.

Expending

2. The obligation of a democracy to report to its citizens-the public is entitled to full information in regard to its school system.

3. The influence which an informational program will have upon the teaching staff-to bring to individual teachers a conception of the whole organization and their part in this whole.

4. The influence which school publicity will have upon the children of the community in bringing to them a knowledge of the opportunities offered them.

5. The effect which such expenditure will have in securing the cooperation of the home, which is all important in the work which the public school is doing.

6. The fact that such expenditure is good business; that education is a product; that the same reasons which exist for advertising any other worth while product hold true for advertising the public schools.

A compilation of representative opinions of superintendents in regard to this matter follows. 
VALID REASONS FOR EXPENDING PUBLIC FUNDS ON PUBLICITY FOR A SCHOOL SYSTEM

The Opinions of Superintendents Relative to Expenditure for School Publicity.
From the Reports of 250 Superintendents of Schools

I. To build up morale in the teaching staff.

"To educate the teaching staff."

2. To influence children to complete their school course.

"Children do what is socially approved."

"To induce children to take advantage of schools."

3. To inform the public about the schools.

"Belief in public schools depends upon how well people know them."

"To acquaint our employers with changes in methods and materials."

"That citizens may understand the scholastic work of the children."

"Accurate and ample information is the first step toward success in any undertaking."-James J. Hill.

"The worst enemies of the schools are those who are most ignorant of what they are doing."

"Without information the layman cannot appreciate his school system, its requirements, and its opportunities."

4. To satisfy a right which the people have to know about their schools.

"To inform the public which pays the bills."

"The public is entitled to know the facts involved in school policies before they become ancient history."

"It allows the public to check the work of the schools."

5. To create cooperation between home and school.

6. To secure financial support for the schools.

"To secure more money."

"To kecp teachers' salaries up."

"People will not support an institution in which they are not interested."

"Self-preservation; no school system can secure funds unless the people believe in the wisdom of the expenditure."

7. To educate the voter.

"To educate the public to the problems and needs of the school." 
8. There is no good reason.

"It is not necessary."

"Should be done only in an emergency."

"School news only read by teachers."

"Papers furnish all necessary news at no cost."

9. To bring about expansion and progress.

Io. To keep public steadily informed so as to ward off damaging reaction.

II. To overcome unfair criticism.

"To remove hostility."

12. It is good business.

"Advertising"

"It pays."

"To sell the schools to the public."

"Education is a product to be sold to the public. The same reasons for advertising this product exist as for advertising any other worth while thing that the public needs.

13. To gain the good will of the public.

14. It tends to increase enrollment and raise the average attendance.

One of the problems which confront the superintendent in his Overcoming relations with the daily newspapers, is that of avoiding the charge of the Charge of partiality in furnishing news. Even though the intent of a super- Partiality intendent in this particular may be entirely good, in practice the On the Part difficulty often presents itself. Many of the superintendents re- of Newspapers. porting stated that they had experienced the charge of partiality, and several admitted that they had been unable to overcome the difficulty. A few newspaper editors in their letters referred to this problem, and expressed the opinion that the fair distribution of news is an essential element in the relations between superintendents and newspaper organizations.

A few superintendents stated that there were, in their respective citics, some newspapers to which they did not care to give school news, because of the character of the newspaper and the manner in which it treated school news when furnished to it. To these superintendents a method of fairly distributing school news has no interest. But to those who realize that each newspaper in a city has its own body of readers, and that this body of readers is as much entitled to information about the public school news as any other group of citizens, the importance of distributing school news fairly to all newspapers is evident. 
Ways of

Oeercoming

the Charge

of Partiality.
An attempt was made in the question sheet to secure the opinjons of superintendents in this particular, and especially to learn some of the methods by which they overcome this charge of partiality. The question asked them was as follows: "Where there are two or more newspapers in a city, if you have ever experienced the charge of partiality in furnishing news to one of them, how have you overcome this?" In general, the methods reported by superintendents in answer to the question can be classified under the following heads:

I. Maintain friendly relations with all newspapers, and arrive at an agreement as to the distribution of school news which will satisfy all.

2. Whenever school news is furnished the press, send duplicate copies to all newspapers.

3. Save all important news for the Sunday editions in which all newspapers get an "even break".

4. Have newspapers agree upon an hour in the day which separates their respective fields.

5. Apply the motto: "First come, first served".

6. Furnish no news to any of the newspapers.

A compilation of the representative opinion of superintendents in regard to methods of overcoming this difficulty follows. In it superintendents may find some suggestion which will help in solving their individual problems.

HOW SUPERINTENDENTS IN GIVING OUT SCHOOL NEWS AVOID THE CHARGE OF PARTIALITY

From the Reports of 250 Superintendents of Schools

I. Give the same material to all papers.

"Furnish duplicate copies of news to all papers."

2. Save important news for Sunday edition.

"In Sunday edition all papers get an 'even break'."

3. Give reporters privilege of getting news at any time. "Give the news to the first reporter on the ground."

4. Give all papers privilege of writing special feature stories.

5. Meet representatives of all papers each day.

6. Create personal relations with newspaper men. "Make friends with the reporters." 
7. Distribute news fairly.

"Arrange the 'breaks' on a 50-50 basis."

"Play no favorites."

"Tactful alternating of news."

"Give each paper exclusive news for a week."

8. "When one paper initiates a story, we give no information to another paper."

9. "When one paper gets a 'scoop', we help the others to get news."

10. Leave the initiative in getting news to the papers; don't "press agent" the schools to the newspapers.

II. Assign a reporter from the system to each paper.

12. Have an agreement with the newspapers.

"Where there are morning and afternoon papers, have them define an hour that separates their fields, e. g., give all news that 'breaks' before I :0o P. M. to afternoon papers, all that breaks after $\mathrm{I}: 00 \mathrm{P} \mathrm{M}$. to morning papers."

"Give news to first paper to have an issue after news becomes available."

13. Never furnish news to any newspaper.

14. Have been unable to solve the difficulty.

15. Never have had the charge of partiality made.

In the opinion of school superintendents, the daily press is a The Importance most important factor, influencing the conduct and progress of the of the Press public schools. In answer to the question, "How important to the to a Public progressive improvement of the school system do you consider the School System attitude of the press?" superintendents were almost unanimous in assigning great importance to the attitude of the daily press. The opinion seems to be almost universal that the daily newspaper has great power to create and mold public sentiment. In view of this, many superintendents expressed the opinion that it is not only good policy, but that it is the definite duty of those in charge of public education to utilize fully this power of the press in the interest of the schools.

In the opinion of some superintendents, the influence of the press depends entirely upon the standing of the individual newspaper in the community. Some superintendents believe that the support of the press is over-emphasized. Some believe that its support is not at all necessary. It may be that in some cities printed material, prepared and distributed directly by the school system, to some ex- 
The Opinion of Superintendents Relative to the

Importance of the Press. tent takes the place of newspaper publicity. These instances, however, are few. The fact remains that the greatest single agency for informing the public about its schools is the daily newspaper. The majority of superintendents reporting had no doubts about this matter. Representative opinions stated by them are presented in the following compilation.

THE IMPORTANCE OF THE ATTITUDE OF THE PRESS TO A PUBLIC SCHOOL SYSTEM

From the Reports of 250 Superintendents of Schools

I. Of the Utmost Importance.

"Invaluable."

"Supreme."

"The deciding factor."

"The biggest single factor."

"All important."

"The most important agency for creating public opinion."

"The support or opposition of the press may make or mar a school system."

"Essential."

"Vital."

"Indispensable."

"A united press spells success."

"A sympathetic press is worth a $\$ 10,000$ appropriation."

"Of tremendous importance provided it is not inspired by school executives or controlled by paid advertising."

"Programs cannot be put over easily or well without the support of the press."

"The press can ruin a school system."

2. Fairly Important.

"Desirable."

3. Not Necessary.

"Much can be done in spite of the press."

"Its importance depends upon the paper."

"Its influence is decreasing because of the use of other printed publicity by school systems."

"I discount most of the supposed influence of the press." 
Daily newspapers do not always handle school news in the best The Treatment possible way. The reasons for this are probably two-fold. In the of School News first place, as was discussed in Chapter III, school people have not by the Local yet learned how to furnish properly written school news for the Press. daily paper. If the rules and suggestions given by editors to school men were followed in the preparation of copy, some of the improper presentation of school news might be avoided. On the other hand, unquestionably the newspaper organizations are at fault in this matter. Those responsible for the conduct of papers no doubt will admit that no more important institution than that of the public school system exists in any community. The proper interpretation of its activities, its progress, and its needs, requires at least a reasonable knowledge of the institution. And yet, to quote one of the editors themselves, "Much school news is given out by educators who do not understand newspapers, and written by reporters who do not understand education".

Superintendents complain that newspapers do not have the school point of view; that immature, inexperienced, and frivolous reporters are too often assigned to interpret the interests of the school to the newspaper reading public; that over-emphasis on the "story" element is often emphasis nnisplaced from the point of view of the public school interests; and that school news often does not receive in the daily paper the prominence and position which its importance warrants.

It is clear that fault exists on both sides. A consideration of the attitude of press and school in this matter may be of benefit to both. The point of view of the editor was set forth in Chapter III. The following compilation, setting forth the opinion of superintendents, represents the point of view of the school in this matter.

\section{FAULTS IN THE TREATMENT OF SCHOOL NEWS BY THE LOCAL PRESS}

From the Reports of 250 Superintendents of Schools

I. News written by those who don't know the thing they write about.

"Much school news is given out by educators who don't understand newspapers, and written by reporters who don't understand education."

"Newspapers lack the school point of view."

"Reporters lack technical knowledge of education." 
Faults of

Newospapers

in Presenting

School News.
"Injudicious criticism of the schools by immature and inexperienced reporters."

"Editors write authoritatively of things without being properly informed.

"Lack of educational editor who understands schools."

2. Emphasis misplaced.

"Emphasis placed on the wrong thing."

"Emphasis on the unimportant."

"Over-emphasis on tax rate."

"Emphasis placed on cost rather than on service rendered."

"Too much space given to athletics."

3. Facts misrepresented.

"Facts distorted."

"Wrong interpretation of facts."

4. Facts mis-stated.

"Often inaccurate."

"Often careless as to facts."

"Frequent exaggeration."

"Failure to verify statements."

"Written too hastily."

5. School news used for political purposes.

6. New's incomplete.

"Too brief."

"All the facts not given."

7. Improper headlines.

"Headlines often misleading."

"Headings often lacking."

"Headlines often too small."

8. News poorly placed.

"School news placed to disadvantage."

"News put in inconspicuous places."

"School news used as filler only."

9. News changed and colored.

"News often colored to suit views of the editor."

"News too often rewritten by editors."

"Statement of facts biased by opinion of editor."

IO. News "story" put ahead of school interests.

"Truth sacrificed for a story."

"News valuc prominent at the expense of social welfare." 
I1. Featuring the sensational.

"Anything to sell papers."

I2. Unfriendly and destructive criticism.

I3. Difficult to get cuts used when furnished.

I4. No faults found.

There should be a philosophy underlying the use of the daily Ethical papers by school administrators. An attempt was made to discover Principles some of the elements of this philosophy by asking superintendents to Governing state those ethical principles which, in their opinion, should control the Use of the use of the newspaper for school publicity purposes. The an- Newspapers swers received are not presented as a philosophy of educational pub- By School. licity in the daily press, but rather as an indication that there are some generally conceded principles which should govern. These principles fall into three rough classes: first, principles relating to subject matter; second, principles affecting the relations between press and school; third, principles relating to the personal element in school news.

A majority of superintendents expressed some opinions as to the ethical principles which should govern school publicity. A consideration of the rules and suggestions of editors as given in Chapter III will reveal certain underlying principles from their viewpoint. The following is a compilation of principles expressed by superintendents. In regard to these, there was a remarkable unanimity of opinion, showing that, in their thinking at least, those who utilize the daily press in the interests of the public schools recognize certain fundamental principles which should govern.

\section{ETHICAL PRINCIPLES GOVERNING THE USE OF THE NEWSPAPERS} BY SCHOOL ADMINISTRATORS

From the Reports of 250 Superintendents of Schools

I. Service of public interest paramount.

"Will it serve the best interests of the children to print this story?"

"Positive upbuilding of the school system should be the governing factor in giving out school news."

2. Maintain right relations with reporters and editors.

"Be impartial."

"Be frank."

"Respect the opinions of the paper."

"Be courteous."

"Take the newspaper men into your confidence."

"Give the opposition of the press due consideration."

"Have confidence in reporters and editors." 


\section{Ethical}

Principles

Which Should

Govern the

Use of

Newspapers.
"Don't ask for suppression of unfavorable news."

"Editor should always have the right to edit any material."

"A newspaper attack is seldom personal, merely a difference of policy."

"Advertising is not news. It should be paid for."

"Consider the intercsts and welfare of the paper."

3. Personal glorification has no place in school news.

"Keep yourself in the background."

"Advertise your schools, not yourself."

"Don't play to the grandstand for personal aggrandizement."

4. Give subordinates credit for work done.

"Give all departments an equal show."

5. Tell the truth always.

"State the real facts."

"Be honest."

"Be scrupulously accurate."

"Tell the truth, even though it hurts."

"Put all the cards on the table."

"In controverted questions, give both sides."

"Never use 'bunk' in school news."

"Don't warp or twist the interpretation of statistics."

6. Develop a sense of proportion in handing out school news.

"Too much publicity is more injurious than none at all."

"Don't expect too much space."

"Use common sense."

"Present only one worth while matter at a time."

7. Don't suppress unfavorable facts.

"Don't try to conceal defects."

8. Never enter into a newspaper controversy.

9. "Be independent." "Be conservative." "Be dignified."

"No publicity at the expense of the dignity of the cause of education."

IO. Use wisdom in the selection of subject matter.

"Don't write unless you have something to say."

"Don't give publicity to intimate matters concerning pupils and teachers."

"Don't complain."

"Don't boast."

"Feature the everyday work of the school, not only the extra activities."

"Make news specific." 
"Comparisons are always odious."

Ethical

"Eliminate personal opinions."

Principles

"Don't exaggerate."

Which Should

"Furnish items of national as well as local interest."

"Never discuss personalities."

Govern the

Use of

Newspapers.

II. Avoid sensationalism.

12. "The less you give the newspapers, the better you will accomplish the work in your school."

"The public school is an established necessity and therefore needs no advertising."

13. "Never use a 'nom de plume' in communications to the paper." 


\section{FORM A}

\section{A Form For Collecting Information on School News or Educational Publicity}

\section{The Subject of this Inquiry is: THE USE AND VALUE OF THE NEWSPAPER AS A MEDIUM OF GIVING PUBLICITY TO NEWS OF THE SCHOOL SYSTEM.}

I have worked on this form to make the answering of it as easy as possible for you. Most of it you ean answer by checking as you read. I shall appreciate your giving as much thought as possible to it.

R. G. REYNOLDS,

525 West 120 St., New York City.

(Your Name)

(Title)

(Address)

\section{Financing School Publicity}

1. What is the total amount of your school budget for 1921-22? $\$$

2. Do you have an item in the budget specifically appropriated for publicity?

3. What is the amount of this item for the year 1921-22? $\$$

4. List the main purposes for which it is spent.

5. If you have no item specifically appropriated for publicity, have you an item or fund which ean be used for publicity purposes?

6. What amount approximately will be used for publicity, 1921-22? \$

7. In your opinion what $\%$ of your school budget should be spent for publicity?

\section{Organization and Personnel}

1. Do you have a person in your system responsible for collecting and releasing school news?

2. What is his name? His title?

3. Does he spend his whole time at this work? His yearly salary?

4. If part time, what proportion is spent in publieity work?

5. If part time, what are his other duties?

6. Do you have a publicity Committce for the entire school system?

7. Of whom is it composed?. 


\section{The Collection of School News}

Which of the following collect school news for newspaper publication?

Answer by checking in the squares.

Daily Weekly Monthly Irregularly Not at all

1. Publicity Director.............

2. Superintendent of Schools........

3. Supervisors..................

4. High School Principals...........

5. Elementary School Principals......

6. Clerk of School Board.............

7. Individual Students.............

8. Individual Teachers............

9. English Classes................

10. Journalism Classes............

11.

12.
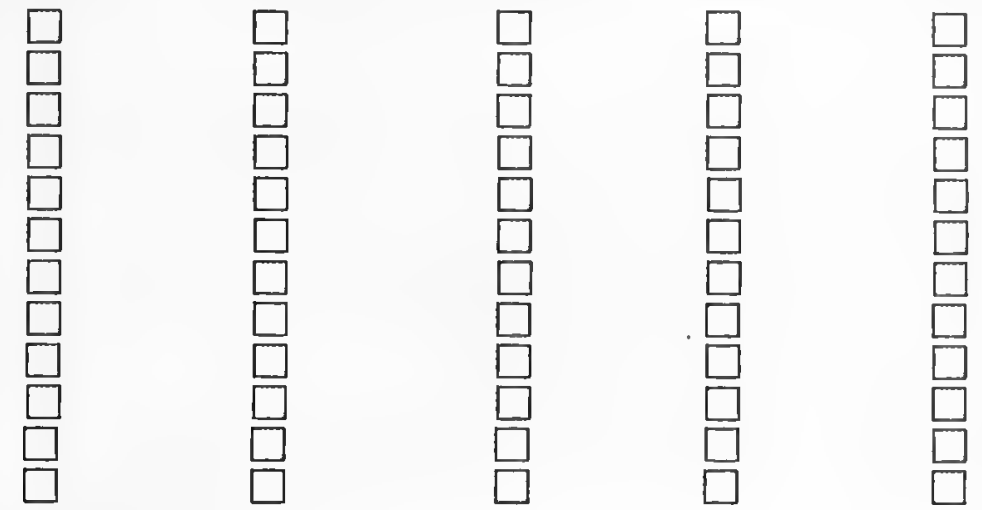

1.

IV. The Editing of School News

1. Does all school news come to the Superintendent of Schools or the Publicity Director for approval before it is released to the newspapers for publication?

2. If not, which of the following types of news are approved and edited by persons other than the writers?

\section{Type of News}

Answer by checking in squares.

Principal Teacher

\section{Approved or Edited by}

English or

Athletic Journalism Student

Coach Class Editors Others
a. School Page or Column
b. Special Feature Articles............
c. High School Notes...............
d. Elementary School Notes..........
e. School Athletic News.
f. Parent Teacher Assn. News........
g. Teachers Club News.............
h. Page, Column, or Dept. contributed by children.................
i. News of School Board Meetings....
j.
$\mathrm{k}$.

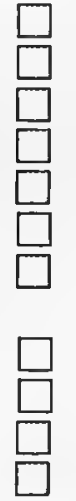

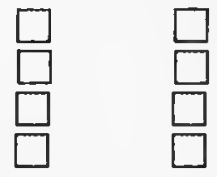
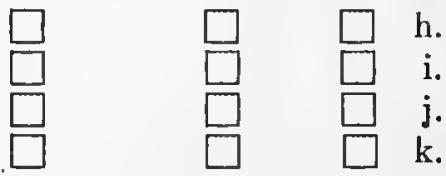

V. Relations with Local Newspaper Organization

Answer by checking in squares.

1. Do papers assign definite reporters to cover school news?

2. Do papers employ paid teacher reporters?........

3. Do papers employ paid student reporters?........

4. Does Superintendent furnish prepared news to

Daily Weekly Monthly Irregularly Not at all

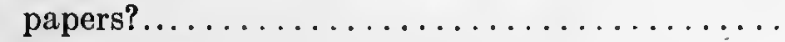

5. Do individual schools furnish prepared news to

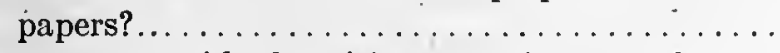

6. Do you use paid advertising space in papers?....

7. If used regularly, for what purposes? 
8. Do papers in your city have an Educational Editor?

Name of Paper.

Which of the following departments devoted to school news are found in your local papers? Answer by checking in squares.

Daily Weekly Monthly Irregularly Not at all

a. A School Page.....

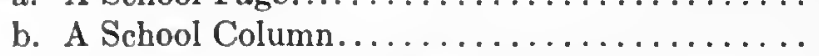

c. Special School News Feature Articles..........

d. Local High School Notes....................

e. Local Elementary School Notes.............

f. Local Public School Athletics.

g. Parent Teacher Assn. Notes................

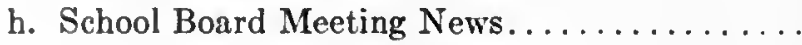

i. Local Teachers Club News..................

j. A Page or Dept. contributed by School Children.........................

k.
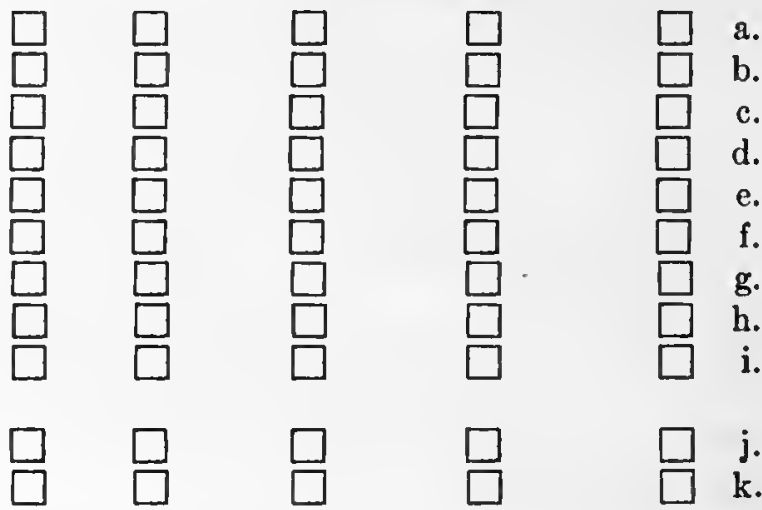

\section{Personal Opinion (Confidential)}

The preparation and publication of school news has not been organized in most school systems. The practice and opinion of leading school men will form a basis for such organization. The answers to the following questions will supply a very valuable body of opinion relative to certain aspects of this problem of properly informing the public about the public schools. Your personal opinion will add to the body of information which is needed. The editors of 100 prominent daily papers have given their opinions in answer to similar questions.

1. List some of the most common faults in the treatment of school news by your local press.

2. Which of the following do you consider the best mediums for reaching your public? Rank them 1, 2, and 3 , as to their effectiveness in getting across school news to the public: Morning Edition.................Afternoon and Evening Edition..................Sunday Edition.

3. On the basis of your opinion, rank the usefulness to the school system of school ncws in the following departments of the daily newspaper. Divide the departments into three groups, placing a figure 1 after those which you have found most useful; a figure 2 after those second best; a figure 3 after those of least value.

1. Editorials.

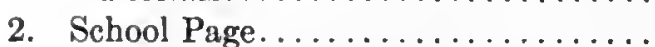

3. Special School Column............

4. Communications Column..........

5. Display Ads by School System......

6. Feature Stories...............

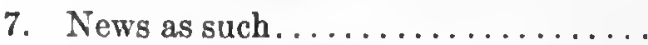

8. Sunday Magazines...............

9. Sunday Picture Supplement.........

10. Page or Dept. by School Children....
11. Commercial Ads co-operating with School System......................

12. Athletic Page or Column...............

13. High School Notes...................

14. Elementary School Notes.

15. Parent Teacher Assn. Notes

16. School Board Mecting Notes....

17. Illustrations, Charts, Cartoons.

18. Entire Issue of Paper by Students........

4. In the various school systems which you have administered, what has seemed to you to be the general attitude or policy of the local press toward those school systems? Answer by checking.

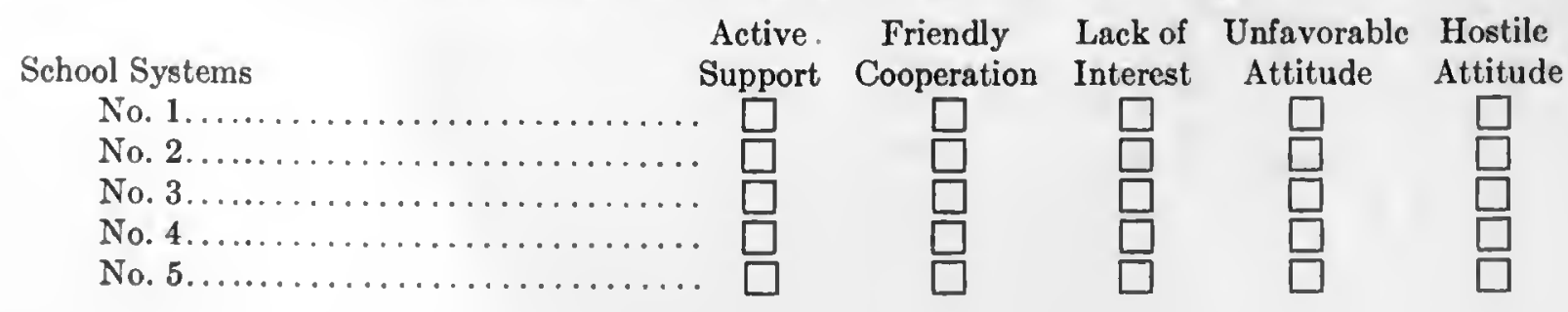


5. Below are listed "units" of continuous publicity campaigns which have been organized and carried out in various school systems. Check those which you have carried on in the newspapers. Add any others.

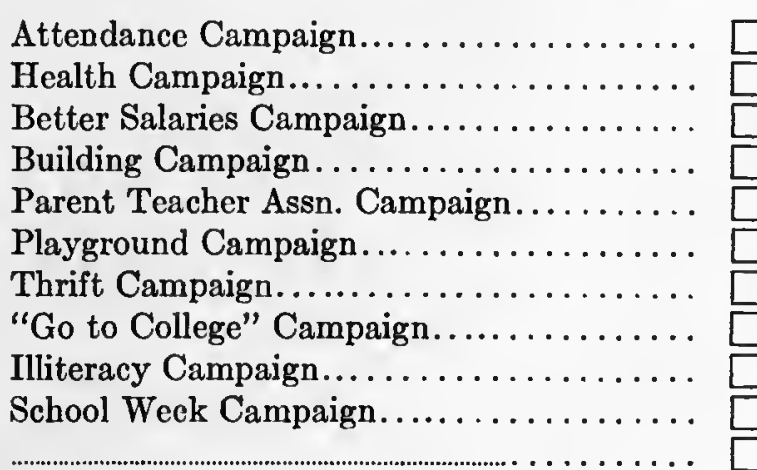

6. In general have you found the editorial column discussing school matters?

I shall appreciate such discussion of the following questions as you care to give.

Please use a separate sheet if necessary.

7. What seem to you to be the most valid reasons for expending public funds on publicity for a school system?

8. Where there are two or more papers in a city, if you have ever experienced the charge of partiality in furnishing news to one of them, how have you overcome this?

9. What is your attitude on cultivating friendly relations with editors and reporters?

10. How important to the progressive improvement of a school system do you consider the attitude of the press?

11. Do you care to list any ethical principles which in your opinion should govern the use of the newspaper by school administrators to give publicity to the school system? 
TABLE IX.

FINANCING PUBLIC SCHOOL INFORMATION SERVICE FROM THE REPORTS OF 250 SUPERINTENDENTS OF SCHOOLS

\begin{tabular}{|c|c|c|c|c|c|c|c|c|c|c|c|c|c|c|}
\hline \multirow{2}{*}{\multicolumn{2}{|c|}{ I }} & \multicolumn{6}{|c|}{$\begin{array}{l}\text { Cities Having a Specific } \\
\text { A ppropriation for } \\
\text { Information Service }\end{array}$} & \multicolumn{7}{|c|}{$\begin{array}{l}\text { Cities Not Having a } \\
\text { Specific A ppropriation } \\
\text { For Information Service }\end{array}$} \\
\hline & & \multicolumn{4}{|c|}{2} & \multicolumn{2}{|c|}{3} & \multicolumn{4}{|c|}{5} & \multicolumn{3}{|c|}{6} \\
\hline & & \multicolumn{4}{|c|}{$\begin{array}{l}\text { Specific Provis- } \\
\text { ion in Budget } \\
\text { for Information } \\
\text { Service }\end{array}$} & \multicolumn{2}{|c|}{$\begin{array}{l}\text { Amount } \\
\text { of } \\
\text { this } \\
\text { Provision }\end{array}$} & \multicolumn{4}{|c|}{$\begin{array}{l}\text { Any other Fund } \\
\text { Which Can be Used } \\
\text { For Information } \\
\text { Service }\end{array}$} & \multicolumn{3}{|c|}{$\begin{array}{c}\text { Approximale Amount } \\
\text { To Be Used for In- } \\
\text { formation Service } \\
\text { 1921-22. }\end{array}$} \\
\hline & & \multicolumn{3}{|c|}{$N U M B E R$} & $\%$ & \multicolumn{2}{|c|}{ NUMBER } & \multicolumn{3}{|c|}{$N U M B E R$} & $\%$ & \multicolumn{3}{|c|}{$N U M B E R$} \\
\hline $\begin{array}{l}\text { Number } \\
\text { Cities }\end{array}$ & Population & No & Yes & $\begin{array}{c}\text { No } \\
\text { Answer }\end{array}$ & Yes & $\underset{\text { imum }}{\operatorname{Max}-}$ & $\begin{array}{l}\text { Min- } \\
\text { imum }\end{array}$ & No & Yes & $\begin{array}{c}\text { No } \\
\text { Answer }\end{array}$ & Yes & $\begin{array}{l}\text { Max- } \\
\text { imum }\end{array}$ & $\begin{array}{l}\text { Min- } \\
\text { imum }\end{array}$ & $\begin{array}{c}\text { No } \\
\text { Answoer }\end{array}$ \\
\hline 29 & Over 100,000 & 25 & 3 & 1 & 10 & $\$ 20,000$ & $\$ 2000$ & 15 & $\mathbf{5}$ & 9 & 17 & $\$ 3000$ & $\$ 0$ & 24 \\
\hline 81 & 30,000 to 100,000 & 73 & 6 & 2 & 7 & $\$ 4000$ & so & 34 & 26 & 21 & 32 & $\$ 1800$ & $\$ 0$ & 47 \\
\hline 140 & Less than 30,000 & 128 & 10 & 2 & 7 & $\$ 1200$ & $\$ 0$ & 45 & 67 & 28 & 48 & $\$ 1400$ & $\$ 0$ & 55 \\
\hline AlL 250 & Cittes & 226 & 19 & 5 & 8 & 320,000 & $\$ 0$ & 94 & 98 & 58 & 39 & $\$ 3000$ & $\$ 0$ & 126 \\
\hline
\end{tabular}

Read the table as follows: Of the school systems in 29 cities of 100,000 and over, 25 have now no specific provision in the budget for information service; 3 have such a provision; $10 \%$ of the whole group have a specific provision; the maximum amount of this provision is $\$ 20,000$; the minimum amount is $\$ 2,000$; etc.

\section{TABLE X.}

\section{PERCENT OF BUDGET WHICH SHOULD BE SPENT FOR SCHOOL INFORMATION SERVICE}

FROM THE REPORTS OF 250 SUPERINTENDENTS OF SCHOOIS

\begin{tabular}{|c|c|c|c|c|c|c|c|c|c|c|c|}
\hline \multicolumn{2}{|c|}{$I-7$} & \multicolumn{10}{|c|}{ Number of Superintendents Recommending } \\
\hline Number of Cities & Population & $3 \%$ & $2 \%$ & $1.5 \%$ & $1 \%$ & $.5 \%$ & $.33 \%$ & $\begin{array}{l}.25 \% \\
\text { or } \\
\text { Less }\end{array}$ & $0 \%$ & $\begin{array}{l}\text { Very } \\
\text { Little }\end{array}$ & $\begin{array}{c}\text { No } \\
\text { Answer }\end{array}$ \\
\hline $\begin{array}{r}29 \\
81 \\
140\end{array}$ & $\begin{array}{l}\text { Over } 100,000 \\
30,000 \text { to } 100,000 \\
\text { Less than } 30,000\end{array}$ & 2 & 5 & 1 & 12 & $\begin{array}{r}1 \\
7 \\
11\end{array}$ & $\begin{array}{l}1 \\
1\end{array}$ & $\begin{array}{r}2 \\
5 \\
13\end{array}$ & $\begin{array}{r}2 \\
8 \\
15\end{array}$ & $\begin{array}{l}1 \\
8 \\
8\end{array}$ & $\begin{array}{l}23 \\
52 \\
73\end{array}$ \\
\hline \multicolumn{2}{|l|}{ AlL 250 Cities } & 2 & 5 & 1 & 12 & 18 & 2 & 20 & 25 & 17 & 148 \\
\hline
\end{tabular}

Read the table as follows: Of 29 superintendents of schools in cities of 100,000 and over, one recommends that .5\% of the school budget be assigned to school information service; two recommend $.25 \%$ of the budget, etc.

TABLE XI.

ORGANIZATION AND PERSONNEL IN SCHOOL SYSTEMS CONCERNED WITH SCHOOL INFORMATION SERVICE

FROM THE REPORTS OF 250 SUPERINTENDENTS OF SCHOOLS

\begin{tabular}{|c|c|c|c|c|c|}
\hline \multirow{2}{*}{\multicolumn{2}{|c|}{ II }} & \multicolumn{2}{|c|}{1} & \multicolumn{2}{|c|}{2} \\
\hline & & \multicolumn{2}{|c|}{$\begin{array}{l}\text { A Person Responsible } \\
\text { for Collecting and } \\
\text { Releasing School News }\end{array}$} & \multicolumn{2}{|c|}{$\begin{array}{l}\text { A Netos Service } \\
\text { Committee for the } \\
\text { Entire School System }\end{array}$} \\
\hline Number of Cities & Population & Number & Percent & Number & Percent \\
\hline $\begin{array}{r}28 \\
81 \\
140\end{array}$ & $\begin{array}{l}\text { Over } 100,000 \\
30,000 \text { to } 100,000 \\
\text { less than } 30,000\end{array}$ & $\begin{array}{r}4 \\
16 \\
32\end{array}$ & $\begin{array}{l}14 \\
20 \\
23\end{array}$ & $\begin{array}{r}2 \\
13 \\
14\end{array}$ & $\begin{array}{r}7 \\
16 \\
10\end{array}$ \\
\hline All 250 Cities & & 52 & 28 & 28 & 12 \\
\hline
\end{tabular}

Read the table as follows: Of 29 school aystems in cities of 100,000 and over, $14 \%$ havo a person responsible for collecting and releasing achool news; $7 \%$ have s news service committee for the entire school system; etc. 
TABLE XII.

HOW PUBLIC SCHOOL SYSTEMS COLLECT SCHOOL NEWS FOR NEWSPAPER PUBLICATION

FROM THE REPORTS OF 250 SUPERINTENDENTS OF SCHOOLS

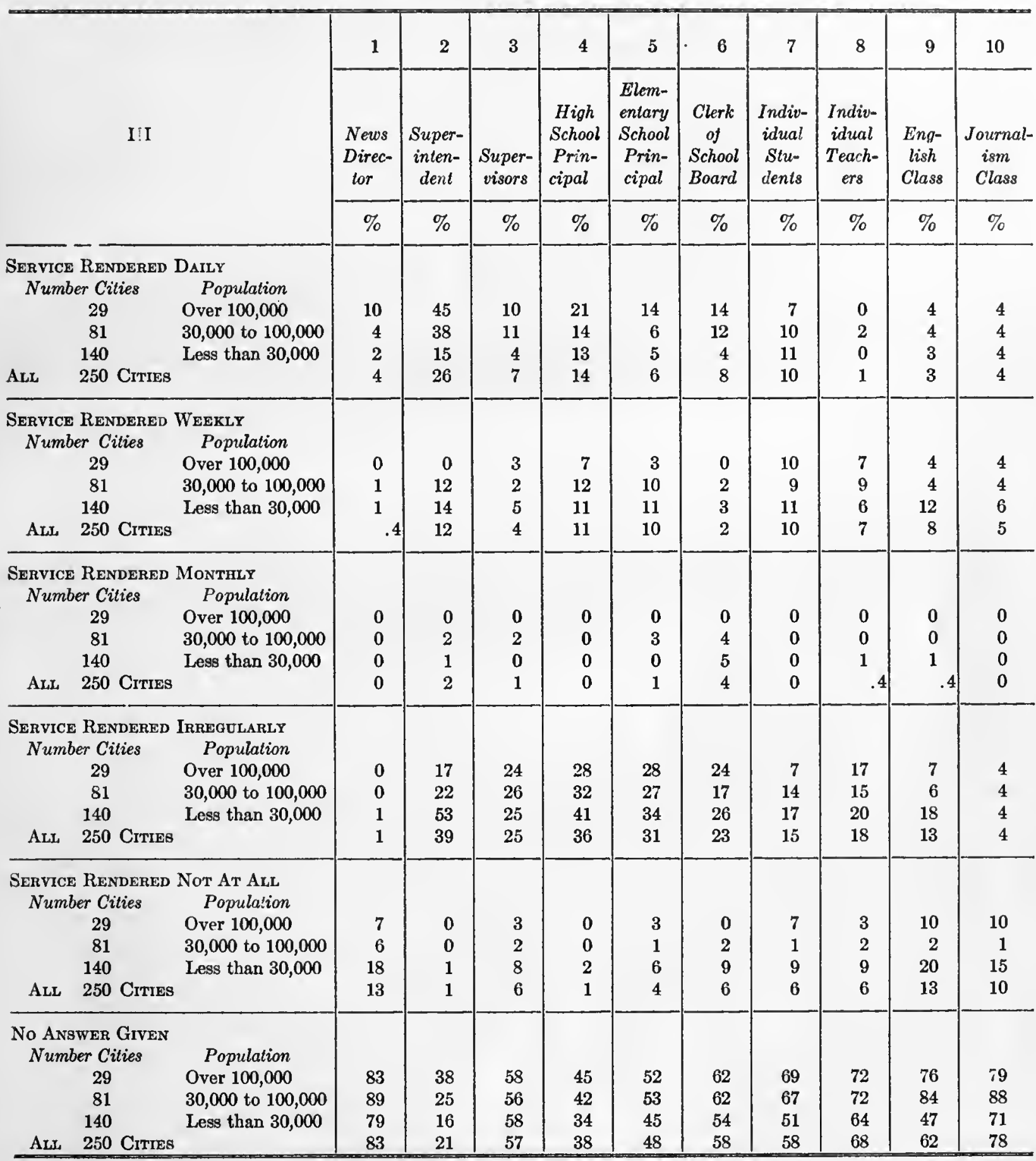

Read the table as follows: Of 29 school systems in cities of 100,000 and over, $10 \%$ have a news director to collect schoo] news; in $45 \%$, the superintendent collects school news; etc. 
TABLE XIII.

THE APPROVAL AND EDITING OF ALL SCHOOL NEWS BY SUPERINTENDENT OR NEWS DIRECTOR FROM THE REPORTS OF 250 SUPERINTENDENTS OF SCHOOLS

IV-I

\begin{tabular}{c|c|c|c|c}
\hline Number of Cities & Population & Yes & No & No Answer \\
\hline & & $\%$ & $\%$ & $\%$ \\
29 & Over 100,000 & 7 & 59 & 35 \\
81 & 30,000 to 100,000 & 28 & 57 & 15 \\
140 & Less than 30,000 & 41 & 46 & 13 \\
\hline All 250 Crties & & 33 & 51 & 16 \\
\hline
\end{tabular}

Read the table as follows: Of 29 school systems in cities of 100,000 and over, $7 \%$ provide that all school news shall be approved and edited by the superintendent or news directors, etc. 
TABLE XIV.

HOW SCHOOL NEWS FOR NEWSPAPER PUBLICATION IS APPROVED AND EDITED BY SCHOOL SYSTEMS

FROM THE REPORTS OF 250 SUPERINTENDENTS OF SCHOOLS

\begin{tabular}{|c|c|c|c|c|c|c|c|c|c|c|c|}
\hline \multirow{3}{*}{\multicolumn{3}{|c|}{ IV }} & $\mathbf{a}$ & b & c & $d$ & $\mathrm{e}$ & f & $\mathrm{g}$ & h & i \\
\hline & & & $\begin{array}{c}\text { School } \\
\text { Page } \\
\text { or } \\
\text { Coiumn }\end{array}$ & $\begin{array}{l}\text { Feature } \\
\text { Article }\end{array}$ & $\begin{array}{l}\text { High } \\
\text { School } \\
\text { Notes }\end{array}$ & $\begin{array}{l}\text { Elem- } \\
\text { entary } \\
\text { School } \\
\text { Notes }\end{array}$ & $\begin{array}{l}\text { School } \\
\text { Ath- } \\
\text { letics }\end{array}$ & $\begin{array}{l}\text { Parent- } \\
\text { Teacher } \\
\text { Associ- } \\
\text { ation } \\
\text { Notes }\end{array}$ & $\begin{array}{c}\text { Teacher } \\
\text { Club } \\
\text { News }\end{array}$ & $\begin{array}{l}\text { Page or } \\
\text { Depart- } \\
\text { ment } \\
\text { by } \\
\text { Children }\end{array}$ & $\begin{array}{c}\text { Board } \\
\text { Meet- } \\
\text { ing } \\
\text { News }\end{array}$ \\
\hline & & & $\%$ & $\%$ & $\%$ & $\%$ & $\%$ & $\%$ & $\%$ & $\%$ & $\%$ \\
\hline \multicolumn{3}{|c|}{$\begin{array}{ccc}\text { EdIted Br Principal } \\
\text { Number Cities } & \text { Population } \\
29 & \text { Over } 100,000 \\
81 & 30,000 \text { to } 100,000 \\
& 140 & \text { Less than } 30,000 \\
\text { Alt } & 250 & \text { Citres }\end{array}$} & $\begin{array}{r}17 \\
21 \\
8 \\
13\end{array}$ & $\begin{array}{l}14 \\
12 \\
10 \\
11\end{array}$ & $\begin{array}{l}24 \\
32 \\
29 \\
29\end{array}$ & $\begin{array}{l}21 \\
32 \\
24 \\
26\end{array}$ & $\begin{array}{r}3 \\
9 \\
11 \\
10\end{array}$ & $\begin{array}{l}14 \\
15 \\
12 \\
13\end{array}$ & $\begin{array}{l}3 \\
3 \\
2 \\
2\end{array}$ & $\begin{array}{r}10 \\
17 \\
1 \\
8\end{array}$ & $\begin{array}{l}0 \\
0 \\
0 \\
0\end{array}$ \\
\hline \multicolumn{3}{|c|}{$\begin{array}{ccc}\text { EdTEd Br Teacher } \\
\text { Number Cities } & \text { Population } \\
29 & \text { Over } 100,000 \\
81 & 30,000 \text { to } 100,000 \\
& 140 & \text { Less than } 30,000 \\
\text { ALL } & 250 & \text { Crties }\end{array}$} & $\begin{array}{l}0 \\
1 \\
6 \\
4\end{array}$ & $\begin{array}{l}0 \\
1 \\
3 \\
2\end{array}$ & $\begin{array}{r}0 \\
11 \\
6 \\
7\end{array}$ & $\begin{array}{l}0 \\
3 \\
4 \\
3\end{array}$ & $\begin{array}{l}0 \\
0 \\
2 \\
1\end{array}$ & $\begin{array}{l}0 \\
1 \\
2 \\
2\end{array}$ & $\begin{array}{r}10 \\
6 \\
11 \\
9\end{array}$ & $\begin{array}{l}0 \\
0 \\
4 \\
2\end{array}$ & $\begin{array}{l}0 \\
0 \\
0 \\
0\end{array}$ \\
\hline \multicolumn{3}{|c|}{ 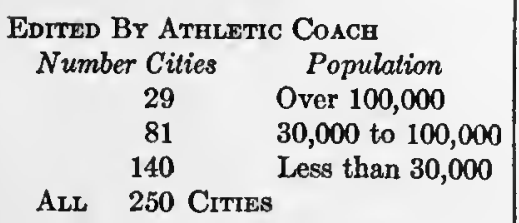 } & $\begin{array}{l}0 \\
1 \\
6 \\
1\end{array}$ & $\begin{array}{l}0 \\
3 \\
4 \\
3\end{array}$ & $\begin{array}{l}0 \\
3 \\
1 \\
2\end{array}$ & $\begin{array}{l}0 \\
0 \\
0 \\
0\end{array}$ & $\begin{array}{l}24 \\
37 \\
37 \\
36\end{array}$ & $\begin{array}{l}0 \\
0 \\
0 \\
0\end{array}$ & $\begin{array}{l}0 \\
0 \\
0 \\
0\end{array}$ & $\begin{array}{l}0 \\
0 \\
1 \\
0\end{array}$ & $\begin{array}{l}0 \\
0 \\
0 \\
0\end{array}$ \\
\hline \multicolumn{3}{|c|}{ 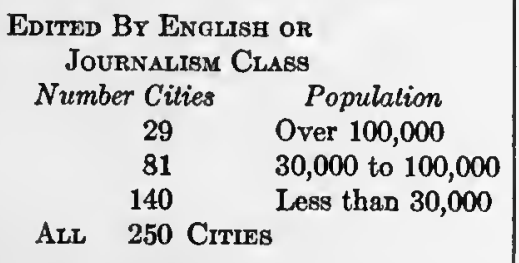 } & $\begin{array}{l}0 \\
1 \\
3 \\
4\end{array}$ & $\begin{array}{l}0 \\
1 \\
3 \\
2\end{array}$ & $\begin{array}{l}3 \\
3 \\
5 \\
4\end{array}$ & $\begin{array}{l}0 \\
0 \\
0 \\
0\end{array}$ & $\begin{array}{l}3 \\
0 \\
4 \\
.4\end{array}$ & $\begin{array}{l}0 \\
0 \\
0 \\
0\end{array}$ & $\begin{array}{l}\mathbf{0} \\
\mathbf{0} \\
\mathbf{0} \\
0\end{array}$ & $\begin{array}{l}0 \\
0 \\
2 \\
.4\end{array}$ & $\begin{array}{l}0 \\
0 \\
0 \\
0\end{array}$ \\
\hline \multicolumn{3}{|c|}{ 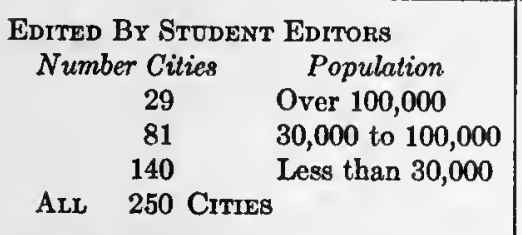 } & $\begin{array}{l}0 \\
0 \\
3 \\
1\end{array}$ & $\begin{array}{l}0 \\
1 \\
4 \\
3\end{array}$ & $\begin{array}{l}3 \\
3 \\
9 \\
6\end{array}$ & $\begin{array}{l}0 \\
0 \\
0 \\
0\end{array}$ & $\begin{array}{l}0 \\
4 \\
4 \\
3\end{array}$ & $\begin{array}{l}0 \\
1 \\
0 \\
.4\end{array}$ & $\begin{array}{l}0 \\
1 \\
0 \\
.4\end{array}$ & $\begin{array}{l}0 \\
0 \\
2 \\
1\end{array}$ & $\begin{array}{l}0 \\
0 \\
0 \\
0\end{array}$ \\
\hline \multicolumn{3}{|c|}{ 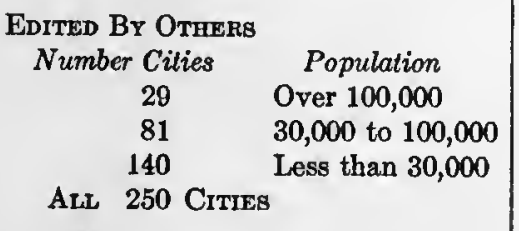 } & $\begin{array}{l}4 \\
6 \\
4 \\
5\end{array}$ & $\begin{array}{l}3 \\
9 \\
5 \\
6\end{array}$ & $\begin{array}{l}0 \\
6 \\
1 \\
2\end{array}$ & $\begin{array}{l}0 \\
4 \\
4 \\
3\end{array}$ & $\begin{array}{l}0 \\
7 \\
2 \\
4\end{array}$ & $\begin{array}{l}17 \\
22 \\
20 \\
20\end{array}$ & $\begin{array}{r}10 \\
15 \\
6 \\
10\end{array}$ & $\begin{array}{r}10 \\
4 \\
2 \\
4\end{array}$ & $\begin{array}{l}24 \\
46 \\
45 \\
43\end{array}$ \\
\hline \multicolumn{3}{|c|}{$\begin{array}{l}\text { No Answer Grven } \\
\text { Number Cities }\end{array}$} & $\begin{array}{l}79 \\
70 \\
72 \\
72\end{array}$ & $\begin{array}{l}83 \\
73 \\
71 \\
73\end{array}$ & $\begin{array}{l}69 \\
43 \\
49 \\
50\end{array}$ & $\begin{array}{l}79 \\
62 \\
69 \\
68\end{array}$ & $\begin{array}{l}69 \\
42 \\
44 \\
46\end{array}$ & $\begin{array}{l}69 \\
60 \\
65 \\
64\end{array}$ & $\begin{array}{l}76 \\
75 \\
81 \\
78\end{array}$ & $\begin{array}{l}79 \\
79 \\
90 \\
85\end{array}$ & $\begin{array}{l}76 \\
54 \\
55 \\
57\end{array}$ \\
\hline
\end{tabular}

Read the table as follows: Of school systems in 29 cities of 100,000 and over, $17 \%$ publish a School Page or Column edited by the principal; $14 \%$ publish feature articles edited by the principal; etc. 
TABLE XV.

RELATIONS OF THE PUBLIC SCHOOL SYSTEM WITH LOCAL NEWSPAPER ORGANIZATIONS FROM THE REPORTS OF 250 SUPERINTENDENTS OF SCHOOLS

\begin{tabular}{|c|c|c|c|c|c|c|c|}
\hline & & 1 & 2 & 3 & 4 & 5 & 6 \\
\hline & V & $\begin{array}{l}\text { Definite } \\
\text { Reporters } \\
\text { Cover } \\
\text { School } \\
\text { News }\end{array}$ & $\begin{array}{c}\text { Paid } \\
\text { Teacher } \\
\text { Reporters } \\
\text { Employed }\end{array}$ & $\begin{array}{c}\text { Paid } \\
\text { Student } \\
\text { Reporters } \\
\text { Employed }\end{array}$ & $\begin{array}{l}\text { Super- } \\
\text { intendent } \\
\text { Furnishes } \\
\text { School } \\
\text { News }\end{array}$ & $\begin{array}{c}\text { Individual } \\
\text { Schools } \\
\text { Furnish } \\
\text { News }\end{array}$ & $\begin{array}{c}\text { Spacc in } \\
\text { Newspapers } \\
\text { Paid for }\end{array}$ \\
\hline & & $\%$ & $\%$ & $\%$ & $\%$ & $\%$ & $\%$ \\
\hline $\begin{array}{c}\text { Service ReNDERED } \\
\text { Number Cilies } \\
29 \\
81 \\
140 \\
\text { ALL } 250 \text { Cities }\end{array}$ & $\begin{array}{l}\text { DaILY } \\
\text { Population } \\
\text { Over } 100,000 \\
30,000 \text { to } 100,000 \\
\text { Less than } 30,000\end{array}$ & $\begin{array}{l}72 \\
48 \\
29 \\
40\end{array}$ & $\begin{array}{l}0 \\
1 \\
1 \\
1\end{array}$ & $\begin{array}{r}21 \\
21 \\
9 \\
14\end{array}$ & $\begin{array}{l}24 \\
20 \\
10 \\
15\end{array}$ & $\begin{array}{c}14 \\
3 \\
4^{.2}\end{array}$ & $\begin{array}{l}4 \\
0 \\
1 \\
1\end{array}$ \\
\hline $\begin{array}{c}\text { Service Rexdered } \\
\text { Number Cities } \\
29 \\
81 \\
140 \\
\text { AuL } 250 \text { Cities }\end{array}$ & $\begin{array}{l}\text { WEEkLY } \\
\text { Population } \\
\text { Over } 100,000 \\
30,000 \text { to } 100,000 \\
\text { Less than } 30,000\end{array}$ & $\begin{array}{l}0 \\
9 \\
6 \\
6\end{array}$ & $\begin{array}{l}0 \\
3 \\
0 \\
1\end{array}$ & $\begin{array}{l}4 \\
4 \\
3 \\
3\end{array}$ & $\begin{array}{r}0 \\
4 \\
10 \\
7\end{array}$ & $\begin{array}{r}0 \\
16 \\
9 \\
10\end{array}$ & $\begin{array}{l}0 \\
1 \\
1 \\
1\end{array}$ \\
\hline $\begin{array}{l}\text { Service ReNdered } \\
\text { Number Cilies } \\
29 \\
81 \\
140 \\
\text { ALL } 250 \text { Cities }\end{array}$ & $\begin{array}{l}\text { MoNTHLY } \\
\text { Population } \\
\text { Over } 100,000 \\
30,000 \text { to } 100,000 \\
\text { Less than } 30,000\end{array}$ & $\begin{array}{l}0 \\
4 \\
1 \\
2\end{array}$ & $\begin{array}{l}0 \\
0 \\
0 \\
0\end{array}$ & $\begin{array}{l}0 \\
0 \\
0 \\
0\end{array}$ & $\begin{array}{l}0 \\
5 \\
3 \\
3\end{array}$ & $\begin{array}{l}0 \\
1 \\
0 \\
\\
.4\end{array}$ & $\begin{array}{l}0 \\
0 \\
1 \\
\quad .4\end{array}$ \\
\hline $\begin{array}{c}\text { Service Rendered } \\
\text { Number Cilies } \\
29 \\
81 \\
140 \\
\text { Alu } 250 \text { Crties }\end{array}$ & $\begin{array}{l}\text { IRregularly } \\
\text { Population } \\
\text { Over } 100,000 \\
30,000 \text { to } 100,000 \\
\text { Less than } 30,000\end{array}$ & $\begin{array}{l}10 \\
23 \\
26 \\
23\end{array}$ & $\begin{array}{l}0 \\
5 \\
0 \\
2\end{array}$ & $\begin{array}{r}10 \\
10 \\
6 \\
7\end{array}$ & $\begin{array}{l}48 \\
58 \\
60 \\
58\end{array}$ & $\begin{array}{l}31 \\
47 \\
40 \\
41\end{array}$ & $\begin{array}{l}35 \\
28 \\
34 \\
32\end{array}$ \\
\hline $\begin{array}{c}\text { Service ReNdered } \\
\text { Number Cilies } \\
29 \\
81 \\
140 \\
\text { ALl, } 250 \text { Crries }\end{array}$ & $\begin{array}{l}\text { Not At AlL } \\
\text { Population } \\
\text { Over } 100,000 \\
30,000 \text { to } 100,000 \\
\text { Less than } 30,000\end{array}$ & $\begin{array}{r}0 \\
4 \\
25 \\
15\end{array}$ & $\begin{array}{l}55 \\
51 \\
63 \\
59\end{array}$ & $\begin{array}{l}28 \\
31 \\
51 \\
42\end{array}$ & $\begin{array}{l}4 \\
3 \\
4 \\
4\end{array}$ & $\begin{array}{l}10 \\
12 \\
21 \\
17\end{array}$ & $\begin{array}{l}31 \\
37 \\
36 \\
36\end{array}$ \\
\hline $\begin{array}{c}\text { No ANswer Givex } \\
\text { Number Cilics } \\
29 \\
81 \\
140 \\
\text { ALL } 250 \text { Citres }\end{array}$ & $\begin{array}{l}\text { Population } \\
\text { Over } 100,000 \\
30,000 \text { to } 100,000 \\
\text { less than } 30,000\end{array}$ & $\begin{array}{l}17 \\
12 \\
14 \\
14\end{array}$ & $\begin{array}{l}45 \\
40 \\
36 \\
38\end{array}$ & $\begin{array}{l}38 \\
35 \\
32 \\
34\end{array}$ & $\begin{array}{l}24 \\
11 \\
13 \\
14\end{array}$ & $\begin{array}{l}45 \\
21 \\
28 \\
28\end{array}$ & $\begin{array}{l}31 \\
33 \\
27 \\
30\end{array}$ \\
\hline
\end{tabular}

lead the table as follows: In $72 \%$ of 29 sehool systems in eities of 100,000 and over, definite reporters are assigned to cover school news; in $21 \%$, paid atudent reporters are employed; etc. 
TABLE XVI.

NEWSPAPERS HAVING AN EDUCATIONAI EDITOR

FROM THE REPORTS OF 250 SUPERINTENDENTS OF SCHOOLS

V-8

\begin{tabular}{|c|c|c|c|c|}
\hline Number of Cities & Population & Yes & No & No Answer \\
\hline & & $\%$ & $\%$ & $\%$ \\
\hline $\begin{array}{r}29 \\
81 \\
140\end{array}$ & $\begin{array}{l}\text { Over } 100,000 \\
30,000 \text { to } 100,000 \\
\text { Less than } 30,000\end{array}$ & $\begin{array}{r}21 \\
9 \\
3\end{array}$ & $\begin{array}{l}52 \\
75 \\
85\end{array}$ & $\begin{array}{l}28 \\
16 \\
12\end{array}$ \\
\hline Ald 250 Cities & & 7 & 78 & 1.5 \\
\hline
\end{tabular}

Read the table as follows: In $21 \%$ of 29 eities with a population of 100,000 and over, at least one newspaper has an educational editor, ete. 
TABLE XVII.

DEPARTMENTS IN DAILY NEWSPAPERS DEVOTED TO SCHOOL NEWS FROM THE REPORTS OF 250 SUPERINTENDENTS OF SCHOOLS

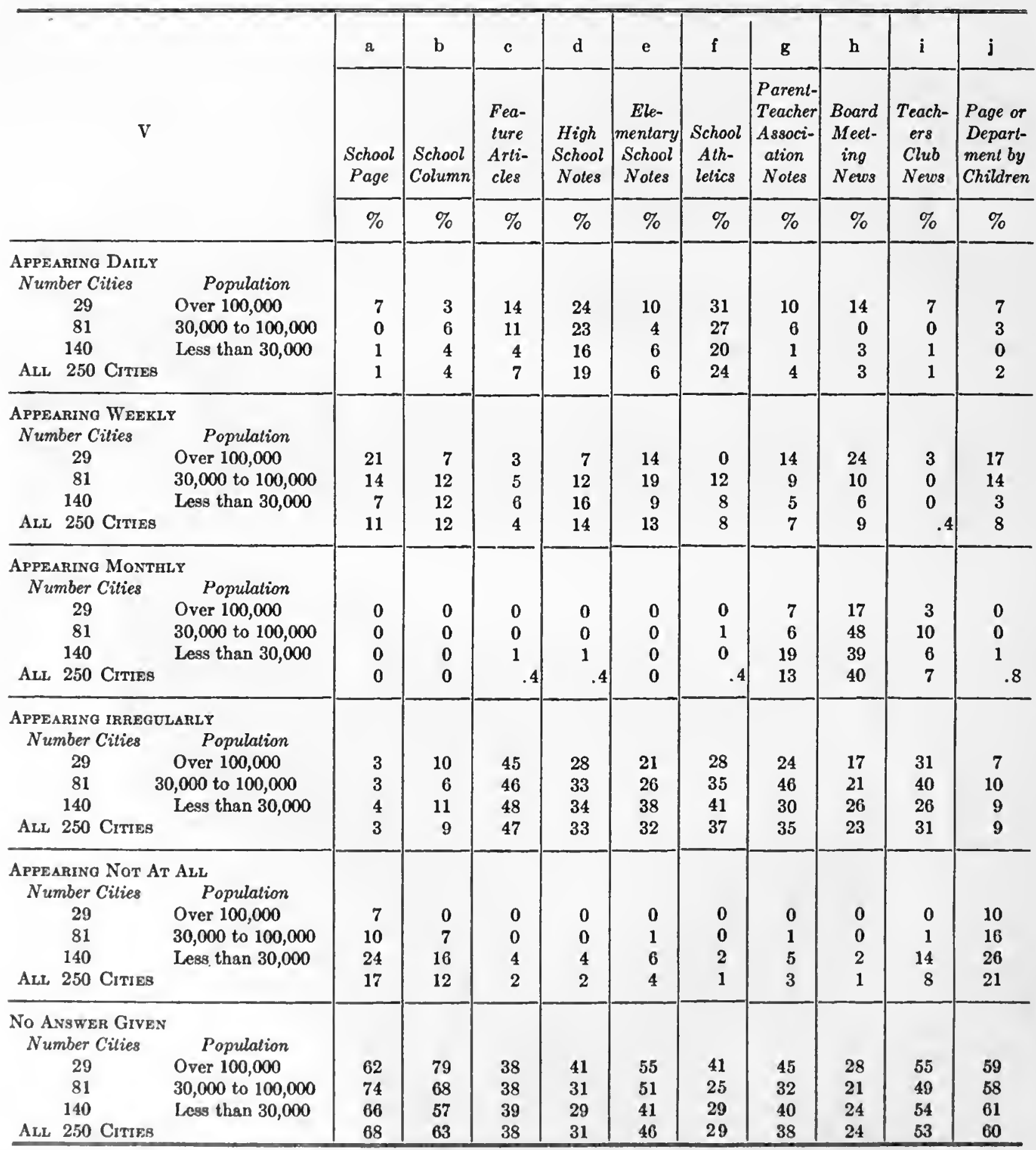

This table is read the same as Table IV. 
TABLE XVIII.

THE ATTITUDE OF DAILY NEWSPAPERS TOWARD PUBLIC SCHOOL SYSTEMS FROM THE REPORTS OF 250 SUPERINTENDENTS OF SCHOOLS

VI-4

\begin{tabular}{|c|c|c|c|c|c|c|c|c|}
\hline \multirow{2}{*}{$\begin{array}{l}\text { Superintendents } \\
\text { Located in } \\
\text { Cities of }\end{array}$} & \multirow{2}{*}{$\begin{array}{l}\text { Number of } \\
\text { Superintendents } \\
\text { Reporting }\end{array}$} & \multirow{2}{*}{$\begin{array}{c}\text { Number } \\
\text { of Daily } \\
\text { Papers } \\
\text { Reported } \\
\text { On }\end{array}$} & $\begin{array}{c}\text { Active } \\
\text { Support }\end{array}$ & $\begin{array}{l}\text { Friendly } \\
\text { Coopera- } \\
\quad \text { tion }\end{array}$ & $\begin{array}{l}\text { Lack of } \\
\text { Inter- } \\
\text { est }\end{array}$ & $\begin{array}{l}\text { Unfavor- } \\
\text { able } \\
\text { Attitude }\end{array}$ & $\begin{array}{l}\text { Hostile } \\
\text { Atti- } \\
\text { tude }\end{array}$ & \multirow{2}{*}{$\begin{array}{l}\text { Number of } \\
\text { Superin- } \\
\text { tendents } \\
\text { Not } \\
\text { Answering }\end{array}$} \\
\hline & & & $\%$ & $\%$ & $\%$ & $\%$ & $\%$ & \\
\hline $\begin{array}{l}\text { Over } 100,000 \\
30,000 \text { to } 100,000 \\
\text { Less than } 30,000\end{array}$ & $\begin{array}{r}22 \\
72 \\
125\end{array}$ & $\begin{array}{r}53 \\
202 \\
372\end{array}$ & $\begin{array}{l}43 \\
38 \\
38\end{array}$ & $\begin{array}{l}40 \\
43 \\
44\end{array}$ & $\begin{array}{r}2 \\
12 \\
10\end{array}$ & $\begin{array}{l}6 \\
5 \\
5\end{array}$ & $\begin{array}{l}9 \\
2 \\
3\end{array}$ & $\begin{array}{r}7 \\
9 \\
15\end{array}$ \\
\hline All 250 Cities & 219 & 627 & 39 & 43 & 10 & 5 & 3 & 31 \\
\hline
\end{tabular}

Read the table as follows: 22 superintendents in cities of 100,000 and over reported that of 53 daily papers with which they had had experience $43 \%$ gave active support to the school system; $40 \%$, friendly cooperation; etc.

TABLE XIX.

DISCUSSION OF SCHOOL MATTERS IN THE EDITORIALS OF DAILY NEWSPAPERS FROM THE REPORTS OF 250 SUPERINTENDENTS OF SCHOOLS

\begin{tabular}{c|l|c|c|c|c|c}
\hline & & Frequently & Occasionally & Seldom & Never & No Answer \\
\hline Number of Cities & Population & $\%$ & $\%$ & $\%$ & $\%$ & $\%$ \\
\hline 29 & Over 100,000 & 31 & 41 & 3 & - & 7 \\
81 & 30,000 to 100,000 & 19 & 43 & 7 & - & 15 \\
140 & Less than 30,000 & 24 & 79 & 22 & 3 & 12 \\
\hline ALL 250 Crties & & 21 & 54 & 12 & 1 & 12 \\
\hline
\end{tabular}

Read the table as follows: $31 \%$ of the newspapers in 29 cities of 100,000 and over discuss school matters in editorials frequently; $41 \%$, occasionally; etc. 
TABLE XX.

THE FREQUENCY WITH WHICH CERTAIN UNITS OF A CONTINUOUS CAMPAIGN HAVE BEEN CARRIED ON IN THE DAILY NEWSPAPERS

FROM THE REPORTS OF 250 SUPERINTENDENTS OF SCHOOIS

\begin{tabular}{|c|c|c|c|c|c|c|c|c|}
\hline \multirow{2}{*}{$\begin{array}{c}\text { VI-5 } \\
\text { Subject } \\
\text { of the Campaign }\end{array}$} & \multicolumn{2}{|c|}{$\begin{array}{c}\text { In } 29 \text { Cities of } \\
100,000 \text { and } \\
\text { Over }\end{array}$} & \multicolumn{2}{|c|}{$\begin{array}{c}\text { In } 81 \text { Cities of } \\
30,000 \text { to } \\
100,000\end{array}$} & \multicolumn{2}{|c|}{$\begin{array}{l}\text { In 140 Cities of } \\
\text { Less than } \\
30,000\end{array}$} & \multicolumn{2}{|c|}{$\begin{array}{l}\text { In All } \\
250 \text { Cities }\end{array}$} \\
\hline & \multicolumn{2}{|c|}{$\begin{array}{c}\text { Number of Times } \\
\text { Reporled }\end{array}$} & \multicolumn{2}{|c|}{$\begin{array}{c}\text { Number of Times } \\
\text { Reporled }\end{array}$} & \multicolumn{2}{|c|}{$\begin{array}{c}\text { Number of Times } \\
\text { Reported }\end{array}$} & \multicolumn{2}{|c|}{$\begin{array}{c}\text { Number of Times } \\
\text { Reported }\end{array}$} \\
\hline & Number & Per cent & Number & Per cent & Number & Per cent & Number & Per cent \\
\hline Attendanee & 5 & 17 & 25 & 31 & 38 & 27 & 68 & 27 \\
\hline Health & 11 & 38 & 39 & 48 & 62 & 44 & 112 & 45 \\
\hline Better Salaries & 12 & 41 & 46 & 57 & 58 & 41 & 116 & 46 \\
\hline Buildings & 12 & 41 & 55 & 68 & 74 & 53 & 141 & 56 \\
\hline Parent-Teacher Association & 3 & 10 & 19 & 23 & 25 & 18 & 47 & 19 \\
\hline Playground & 2 & 7 & 20 & 25 & 36 & 26 & 58 & 23 \\
\hline Thrift & 9 & 31 & 30 & 37 & 48 & 34 & 87 & 35 \\
\hline Go to College & 0 & 0 & 7 & 9 & 11 & 8 & 18 & 7 \\
\hline Illiteracy & 6 & 21 & 15 & 19 & 20 & 14 & 41 & 16 \\
\hline School Week & 7 & 24 & 27 & 33 & 44 & 31 & 78 & 31 \\
\hline What the School Is Doing & 6 & 21 & 17 & 21 & 36 & 26 & 59 & 24 \\
\hline Recruiting of Teachers & 2 & 7 & 4 & 5 & 5 & 4 & 11 & 4 \\
\hline Americanization & 9 & 31 & 30 & 37 & 34 & 24 & 73 & 29 \\
\hline Night Scbool & 11 & 38 & 43 & 53 & 45 & 32 & 99 & 40 \\
\hline Go to High School & 7 & 24 & 19 & 23 & 28 & 20 & 54 & 22 \\
\hline Safety First & 13 & 45 & 29 & 36 & 20 & 14 & 62 & 25 \\
\hline Bond Issue & 6 & 21 & 37 & 46 & 62 & 44 & 105 & 42 \\
\hline Patriotism & 4 & 14 & 7 & 9 & 15 & 11 & 20 & 10 \\
\hline Know Your City & 5 & 17 & 10 & 12 & 7 & 5 & 22 & 9 \\
\hline School Tax & 1 & 3 & $\mathbf{0}$ & 0 & $\mathbf{0}$ & 0 & 1 & .4 \\
\hline School Lunch & 1 & 3 & 0 & $\mathbf{0}$ & 0 & 0 & 1 & .4 \\
\hline Junior High School & 1 & 3 & 1 & 1 & 1 & 1 & 3 & 1 \\
\hline Clean Up & 0 & 0 & 2 & 2 & 1 & 1 & 3 & 1 \\
\hline Courtesy & 0 & 0 & 1 & 1 & $\mathbf{0}$ & 0 & 1 & .4 \\
\hline Good English & 0 & 0 & $\mathbf{0}$ & $\mathbf{0}$ & 2 & 1 & 2 & 1 \\
\hline City Beautiful & 0 & 0 & 1 & 1 & 0 & 0 & 1 & .4 \\
\hline Junior Red Cross & 0 & 0 & 1 & 1 & 0 & 0 & 1 & .4 \\
\hline School Gardens & 0 & 0 & 1 & 1 & 0 & 0 & 1 & .4 \\
\hline No Answer & 8 & 28 & 21 & 26 & 24 & 17 & 53 & 21 \\
\hline
\end{tabular}

Read the table as follows: In 29 citics of 100,000 and over, 5 superintendents, or $17 \%$, reported that they had carried on an attendance campaign in the daily newspapers; 11 superintendents, or $38 \%$, a health campaign; cte. 
TABLE XXI.

THE BEST EDITION OF NEWSPAPERS FOR CARRYING SCHOOL NEWS FROM THE REPORTS OF 64 SUPERINTENDENTS OF SCHOOLS

\begin{tabular}{|c|c|c|c|c|c|c|c|c|c|c|}
\hline \multicolumn{2}{|c|}{ VI-2 } & \multicolumn{3}{|c|}{ Morning Edilion } & \multicolumn{3}{|c|}{$\begin{array}{c}\text { Afternoon and } \\
\text { Evening Edition }\end{array}$} & \multicolumn{3}{|c|}{ Sunday Edition } \\
\hline Number of Cilies & Population & $\begin{array}{c}\text { Ranked } \\
1\end{array}$ & $\begin{array}{c}\text { Ranked } \\
2\end{array}$ & $\begin{array}{c}\text { Ranked } \\
3\end{array}$ & $\begin{array}{c}\text { Ranked } \\
1\end{array}$ & $\begin{array}{c}\text { Ranked } \\
2\end{array}$ & $\begin{array}{c}\text { Ranked } \\
3\end{array}$ & $\begin{array}{c}\text { Ranked } \\
1\end{array}$ & $\begin{array}{c}\text { Ranked } \\
2\end{array}$ & $\begin{array}{c}\text { Ranked } \\
\quad 3\end{array}$ \\
\hline 12 & Over 100,000 & 3 & 5 & 4 & 8 & 2 & 2 & 1 & 5 & 6 \\
\hline 24 & 30,000 to 10,000 & 5 & 7 & 12 & 10 & 10 & 4 & 9 & 7 & 8 \\
\hline 28 & Less than 30,000 & 4 & 10 & 14 & 14 & 10 & 4 & 11 & 7 & 10 \\
\hline \multicolumn{2}{|l|}{ All 64 Cities } & 12 & 22 & 30 & 32 & 22 & 10 & 21 & 19 & 24 \\
\hline
\end{tabular}

Read the table as follows: Of superintendents in 12 cities of 100,000 and over, in which there were three newspaper editions published, 3 ranked the morning edition first in effectiveness; 5 ranked the morning edition second; etc. 
THE DES MOINES REGLSTER: MONDAY DFORMTY

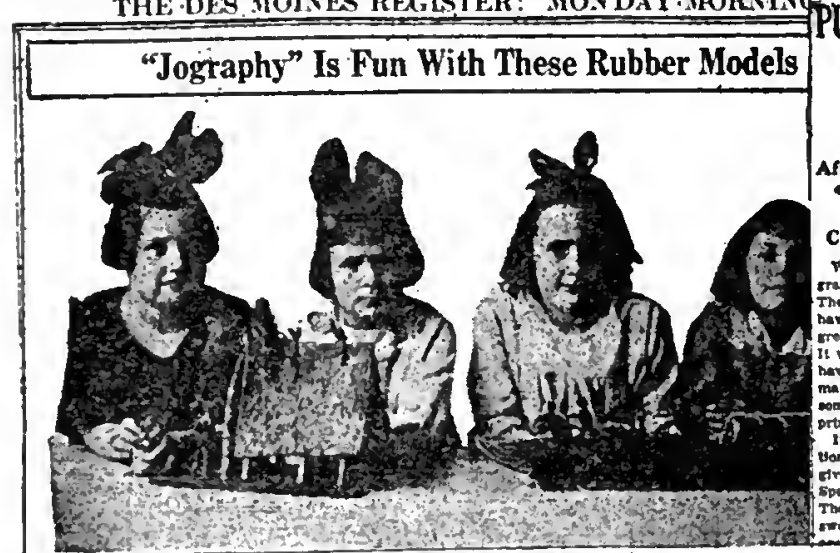

FLAG ONLY REDEEMING THING ABOUT OLD SCHOOL BULDNG

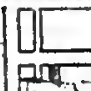

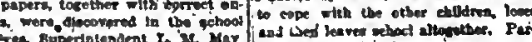

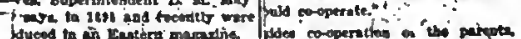

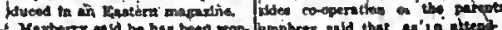

Dr. Englehardt, Expert in School Planning. Makes In. USE SEATS GRANDPARENTS USED apection of East Main Street Structure and C THE UNION, MANCFESTER, N. H. TW

High School Wireless Course Elective Study

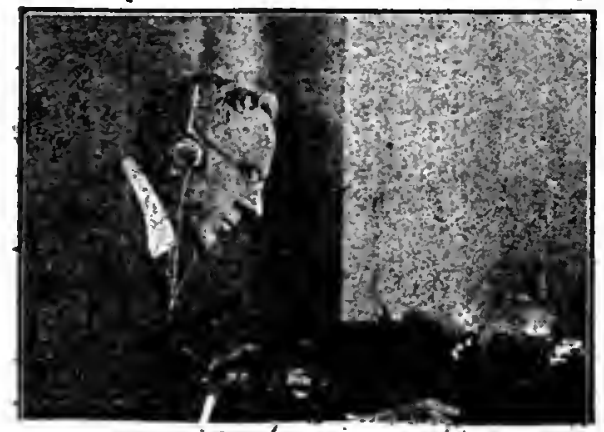

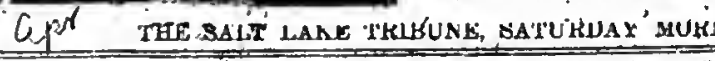

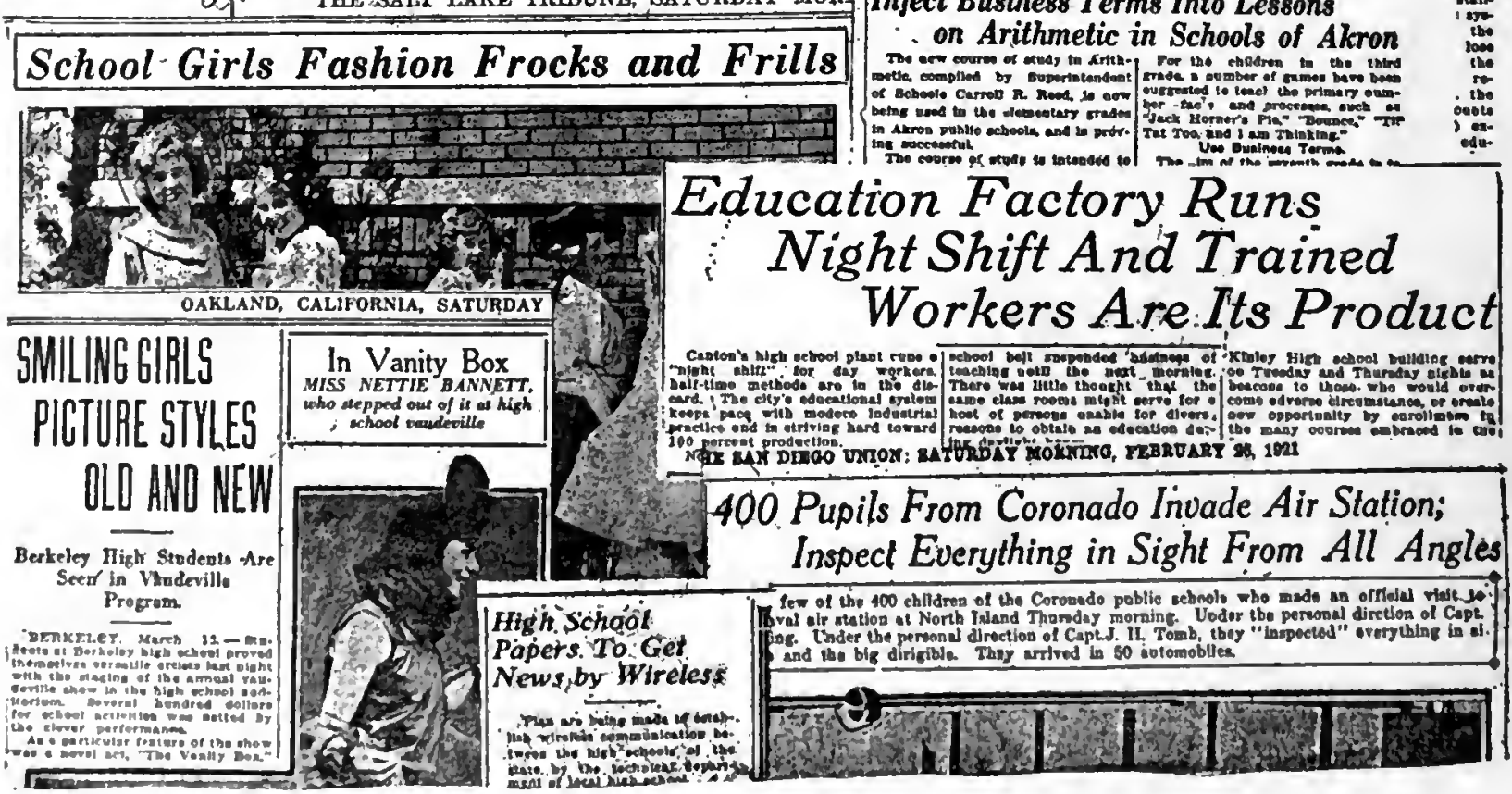

ONE-THIRD OF CANTON: PUPILS OPEN ACCOUNTS IN NEW SCHOOL BANKS

Boys And Girls Save Money For Bicycles, For Clotheo, For Dresses, For Mother And For CollegeDeposits Average Seven Cents.

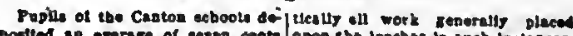

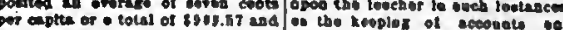

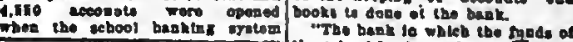

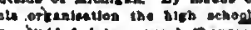

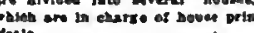

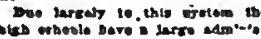
tratre mak,

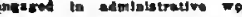

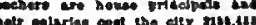$$
\text { Trioct Bus }
$$

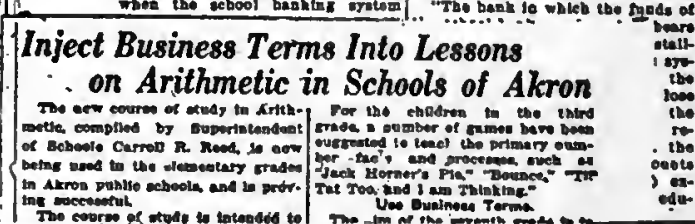

"House" Plan Held by Somo Costly.

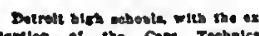

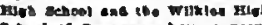
is 


\section{CHAPTER V}

\section{SCHOOL NEWS FROM THE NEWSPAPER READER'S VIEWPOINT}

\section{GENERAL STATEMENTS}

If it were known just what effect a piece of printed material would have upon the one who reads it in a newspaper, the value of that piece of publicity could be definitely stated.

This chapter is an attempt to discover by experiment which type of public school news is most interesting to the general newspaper reader.

In brief the conclusions arrived at are as follows:

There is rather close agreement on the part of 403 readers as to the interest created in their minds by ten different newspaper articles submitted to them for judgment.

In general, newspaper readers, without respect to their occupation, agreed in their judgments.

However, a group which may be designated as commercial publicity experts did not agree in some respects with the other occupational groups.

The scale on newspaper articles, together with a reproduction of the articles which determined the points on the scale, are not presented as a device to measure the effectiveness of newspaper articles in general. They are presented as an indication that in the minds of the general newspaper reading public, there is an agreement as to a good newspaper article on school matters and a poor one.

\section{MATERIAL COLLECTED AND METHOD USED}

A large number of newspaper clippings on the subject of the health of school children were collected. From these clippings those were selected which dealt with malnutrition. By a statistical process of selection, ten of these articles were chosen by 50 judges as ranking in fairly equal steps from lowest or worst to highest or best.

These ten articles were reproduced on a broadside which is presented as Form 5, page 82. Six hundred of these broadsides were distributed in all parts of the country, and to as many persons in as many different occupational groups as possible. These newspaper readers were asked to rank the articles in the order in which they aroused "the greatest interest in the health of school children". The exact instructions given can be ascertained from the "Directions" in form 5 . The following are the facts relative to the replies received. 
The Distribution of the Broadsides.
Statistical

Treatment of the Judgments.
I. "Broadsides", on which each article was given some rank, were received from 403 judges.

2. These judges resided in 35 different states.

3. Of the judges, 162 were women and 241 were men.

4. From a statement of occupation reported on the broadside by each judge, they were divided into ten occupational groups as follows:

(a) Public School Administrators.

(b) High School Principals.

(c) Public School Teachers.

(d) Professional Advertising Women.

(e) Housewives.

(f) Persons in Professions other than Educational.

(g) Persons in Business.

(h) Clerical Workers.

(i) Artisans and Laborers.

(j) Newspaper Workers.

These 403 judges therefore represent both sexes, a wide geographical area and a diversificd occupational status. They are fairly typical of the general newspaper reading public.

To the rankings received, the statistical method of right and wrong cases ${ }^{1}$ was applied, the theory of which may be stated as follows: Differences that are equally often noticed are equal unless the differences are always or never noticed.

For the purpose of facilitating the work, the median ranking given to each article by each occupational group was determined.

The median ranking of each group is the middle value assigned by each group to each article. Half the judges gave each article a ranking less than its median or middle ranking, and half the judges gave the article a ranking greater than the median. In Table XXII, page 93 these medians are tabulated. A study of them shows the general agreement of all groups as to the value of each article. The exception is the advertising-women's group, which differs somewhat in opinion from the others.

\footnotetext{
'Fullerton and Cattel - On the Perception of Small Differences, pp. $12 \mathrm{ff}$.
} 
It was desired from the judgments received to construct a rough scale which would indicate the relative value of the articles under consideration.

The theory of the method employed in deriving the scale was the same as that employed by Dr. M. B. Hillegas ${ }^{1}$ in his derivation of a scale for the measurement of quality in English composition. It will not be discussed in detail here. The statistical material from which the scale was derived is found in Tables XXIII, XXIV, and XXV, pages 93 and 94 .

\section{A SCALE OF NEWSPAPER ARTICLES}

It was evident from the judgments of the various groups that there was little variation as to the relative position which they assigned to each article. Therefore, the judgments of all the groups were brought together and a composite ranking obtained. Since the women advertisers as a group differed considerably from the others, their judgments are not included in the composite ranking but presented separately.

A graphic representation of the composite judgment is presented in Figure I, below. The newspaper articles which are represented on the scale by the letters $G, F, I, B, C$, are presented in Figures $2,3,4,5$, and 6 , pages 83 to 87 inclusive.

This scale means that of the ten newspaper articles judged by the composite group, Article $\mathrm{G}$ gave least interest in the health of school children, and Article $\mathrm{C}$ gave the most interest. Article $\mathrm{F}$ is I.09 units "better" than Article G; Article I .88 units better than Article F; and so on. The articles illustrating this Scale are found in Figures 2 to II, inclusive.

FIGURE 1.

A Graphic

Representation

A Scale of Newspaper Articles

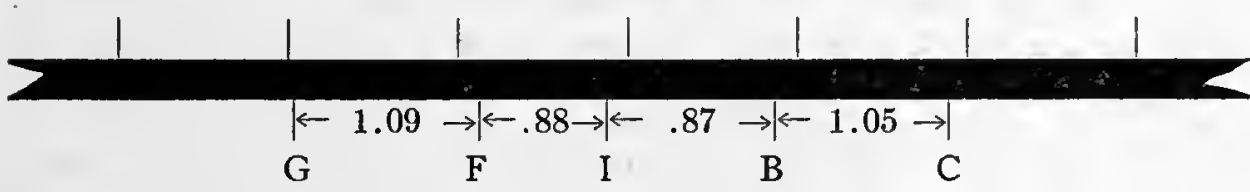

of the Scale.

$\mathrm{H}$ falls between $\mathrm{F}$ and $\mathrm{I}$

$J$ falls between I and B

$\mathrm{E}$ falls between $\mathrm{F}$ and $\mathrm{I}$

$D$ falls between $B$ and $C$.

$A$ falls between $I$ and $B$

${ }^{2}$ M. B. Hillegas-Scale for the Measurement of Qualities in English Composition by Young People, pp. 14 ff. 
WHAT THE SCALE MEANS

An Explanation of the Scale.
I. Of the ten newspaper articles printed on the "broadside" Article $\mathrm{G}$ is considered the poorest in the composite opinion of all the judges. Article $\mathrm{C}$ is considered the best. The others are scattered between, as indicated on the scale.

2. How the unit of measurement is determined: Consider two hypothetical articles, $\mathrm{X}$ and $\mathrm{Y}$. The unit of measurement on the scale would be the difference between $X$ and $\mathrm{Y}$ if $75 \%$ of the judges agree that Article $\mathrm{X}$ is better than Article $\mathrm{Y}$, and only $25 \%$ consider Article X worse than Article $\mathrm{Y}$. In this hypothetical scale, Article $\mathrm{X}$ would be placed exactly one unit higher than Article Y. Returning to the newspaper scale with this unit of difference in mind, it will be seen that in the composite judgment there is a little more than one unit's difference between Article $G$ and Article F, - to be exact, r.09 of a unit's difference. This means that slightly more than $75 \%$ of the judges considered Article F better than Article G. In the same way, slightly less than $75 \%$ of the judges considered Article I better than Article F; and so on. In other words, the differences between Articles $G$ and F, F and I, I and B, B and C, are nearly the same; in each case, this is a difference upon the direction of which approximately $75 \%$ of the judges agreed as illustrated above.

3. No absolute zero point was determined for the scale, and therefore the scale is relative not absolute. This means that no absolute value is assigned to the articles; Article $G$ is not evaluated except in relation to the other nine articles; it is worse than any of them. In the same way, the position given to Article $\mathrm{C}$ is relative,--it is better than any one of the other nine. It is valid to state that Article $\mathrm{C}$ is approximately 2.80 units better than $F$, but we cannot state that $C$ is three times or ten times as good as F. In other words, we can state that one article is so many units better than another article, but we cannot use any times-as-good comparison. 
Articles A, D, E, H, and J, are not given a position on the scale, Articles not since it was desired to fix only those points which came nearest to Represented differing one unit from each other. The relative position of these on the scale articles is as follows: Articles $\mathrm{H}$ and $\mathrm{E}$ both fall on the scale between Articles $F$ and I. Articles $J$ and $A$ both fall on the scale between Articles I and B. Article D falls on the scale between Articles B and C. These articles are presented in Figures $7,8,9$, I0, $\mathbf{1}$, pages 88 to 92 inclusive.

In general, the advertising-women's group ranks the articles the same as the others with the following exceptions: Article A is ranked by the women advertisers as the best article or highest on the scale in place of Article $C$, as chosen by the others; Article C, which the others give the highest rank, the advertising-women's group places much lower. 

The five newspaper articles which follow are the ones represented on the scale.

FIGURE 2.

Newspaper Article-G.

Northwestern

Club to Open

Clinic Monday

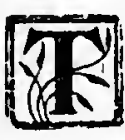

He regulas meeling of the Northwestéru IVoman's Club was held at Diamond Tcmple, Jan. 3.

An interpretalion of Van Dyke's "The Other Wise Man," was given by. Mrs. Wirick Shafor. Mrs. Bertha Stoll. pianiste. gave the FonIasic Impromptu (Chopin). Mrs. John Maney, accompanicd by Mrs. rredertck Covert, sang a group of sengs loy Burlelgh. Both numbers "sre thoroughly enjoyed.

Mrs. B. R. East, chairman of the (hild welfare committee, Introducéd Dr. Palmer, of the board of educafion. Who spoke of the malnutrition rilnle to be opened in the clinton school, Jan. 10, by the Northwestern Worman's Club wlth the co-operatlon of the Vislting Nurses' Association and the board of health.

It is the intention of the cllnic to Eive a substantial noon meal to a croup of 50 children, and the result up this experiment will enable the board of education to definitely de. cide future aivion in the matter.

IIiss Nila Smith, supervisor of the primary grades of the elty schools, spoke from the standpoint of the teacher. of the "profect" innthod whith is now belng used in the schools.

Mlss. Ellzabeth Cleveland, superV'sor of rocational training, extended an Invitation to the club to visit the new Teachers' College.

The philanthrople committec, Mrs. Walter parmalee. clialruan, arinounces an evening of eards and dancing at tho Federation Clubhousc, Jan. 11.

The next meeting of the study class wlll we held Jal 10. Mrs. willard Underill will present. a paper, "Progress of Mlodern Invention." Roll edil will bo responded to ly a summary of "Things we would like to have invented.". 
FIGURE 3.

Newspaper Articlo-F.

\section{SCHOOLPUPILS \\ IN BERKELEY \\ UNDER WEIGHT}

BERKELTYY, F Feb. 19. - FIIT per cent of the puplls in five Berfeley schools visited have been found to be-underwelght, aays MIss filorence Boddy, superintendent of health visitors of the college city. Tho pounds which are lacking Tho pounds which are lacking
to bring the children up to normal vary from $1 \frac{1 / 2}{20} 13 \% / 2$, slates Miss Boddy, the average being $7-35$ younds. Discovery of the hsortcomings of the puptla lollowed welghing done by schon! nunrses under Mişa Boddy's supervision.

Defects follnd in chlidren' in al of the Berkeley achools numbercd 2452 with the beginning of school nursing work last year, says MIss Hoddy Gpecial attention is belnts Given by che health visitors to the Fiven by the health risitors to the
curing of speech defects and $a$ clinic for this purpose has becil opened for children of the cl' ine Berkeley dlspensary. 
FIGURE 4.

Newspaper Article-I.

\section{MOTHERS' CLUB SUCCEEDS IN IMPROVING CHILDREN'S HEALT}

"Sturdy boys anda girls in body'as and Mrs. Bucklin. "il:"s. J. Ts. Mounds we!l as bl mind."

nili sive a short ta!k. A silver, ofier.

Ing w?ll be tilien tol th 3 clulis now

$\therefore$ That is tho unwritten slogan of a a

roup of Hanline mothers interestcd In chlld welfaro work in thelp particular corinumity. As re result the millk istion at the Hirncock scl:ool intul tho recént weighing and ineasiring work'brought forth soms. Nor verful rysults ' in 'buliding. u! unexpetsed, inderivurished ehitiren

- The Hamlinc Alothers' club activi-

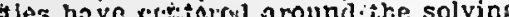
teic two chice enierprises so fai havo lieen the continution and develop'mnnt of the milk slatton and the :nurias syatem fow in operation."

First Meeting in December.

- The tirost clifid relfite merting was held in vocenitar. When the club heard atiss Lucy Coidinler talk about the food aikd diztifs of children and stresed the betants: io be gainced from systemat? weighios and meas uring: A bpoc J child vieifare mect ivg mas planned sor. February in the assemily foom of the Hancosk schoel when exhlblt posters were on view. At this gatliering the 'health alphabet" book was distributed as souve nirs. The chool nisso requested co. operation of pardnts and children. Dr. J. A. Meyerding and with one of his assietants denioustiated operaten or acalcs and cxplained tho syse ini $A$ th the boys and girls of the sçhool hns now. been weished, and ineaturesl and the club will again hear Mtss Cordlnier at in special proGrom itt P. M. Tiudnesday at the schonl. Mrs. Inct C. Buclilin's dramidizatlon from ".Cho-Clio and the Ficalsh Fatry" wlil be tiven by the litic chilldien of the schoo!.

ric Morthes's oluh has its cye on cmeiney and a rost room for the cacic.... With this in misu ain en ferlabirasent and community reception witl lake piace at 8 P. M. lomorrow in the nswentbly roon of the achool. A in the Hith his bicn flur.ı:ed by MTS. M. E. Old president of the rlub and MIs. IV. Tugect is cis secretar eommittee: Mrs. Siclney Horsle;, chit] wclfurc, and Mis. Tinnas, T. Beser, proErani.

\section{Opened Last Spring.}

The milk 'stîtion opened. last rine rive ortiac daily clistribution Wis 120 bottles, cacls clilla payinz celits a bottle. 'The cariy part of in s viir with inili at conts consumption decreased. After Cribisiras, Jowever fullowing the impeius of the child wcitare ralis with milk"aguln at' 3 cuts the distriburion reaclied 310 botcents the IVith the colying of the mighin: and measuring probian

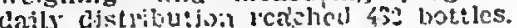
Tho Haiscork mik station is the only cne in the city that has bren self suppxorting fioul its liconnins. in rs. Iussctt with her slafi of twenty pears every day and proves a veritable hollse-mother to the school kiddies. Firet she was linown among the boys and girls as the "milk-tcacher, "ow' she is the "mill- mother."

The children are jnterested in being icisined and measurcil. Mis. $\mathrm{K} A$ Johnxop liag charge of the work and bas three iss!3tasits. The work has developcd to stuch an extant that "five assigtants are kept busy. In the cll rolingut of 893 children 211 or is cent or more arc underiveistit; 110 or more are underiveisit; 110 or 1.3 per cent are. 10 per cent malciweight. The 7 per cent inderwoights vill be weighed oach month aud al tho children will again be weighed before school closes for the summer vacalion. It is a plan of the jnothers to have n uutrition class for tir nun to of tion of tise orincipal of the school. Mirs Edith Taylor, the tenchers. muises, parents and children has madc the work a profitr.ble and pleasurable onc, sajd mo:hes'sesterday. The helpers are all voluniecrs. 
FIGURE 5.

Newspaper Artiele-B.

\section{Large Gains in Weight and Health. of Pupils Are Found by Nuritition Class Worker on Her Visit to City}

I Miss Jable Skilton, of liostna, nutri-|directet? ly Mis: L nis Iiemage aud Miss

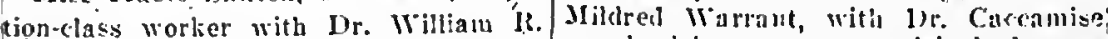
1․ Encroon, arrived in Lionlester yesterday and risited sereral nutrition classes. Miss Shilton will reunain in the city for two weeks risiting the present classes and assisting lu organizing new classes. Dr. Limerson will roune later to cunfer with uutrition workers.

Miss Skilton risited the clinss at jo. :i School, of which Miss Mildreil (amplelt and Ior. Miller hare elarge. The frains in this class have been cxeellent, one child haviur heen graduated. Jommett leake is the first child in the looely-

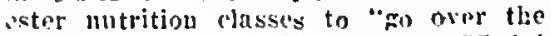
top." Ilis wejwlit wrut from $51-4$ mounds to 6j- 1-2 pounds in fourteris weeks. Vext weok he will be presenterl his diplome hy Di. limerson nud will receive a prim for being the first of the his rlass to die mradunted. In important findir:m in the rlass ut Xo. : Schnol is that fourten of twentrone in the class are reporterl he their teachers to hare improred mentally as well as physically. The totil mumber of pouthds gaille, in the fourtem werlis is 1800. Of those wid diil not gnin it was disrovered that they were not gettin: to lod carly.

"One of the limst tricks to gain is anince to lwed bilrly." said MIss: Skilton in adrlressin:" the class. "Every hoy and firl in a nutrition rlass should he in heal it $\leqslant: \% 0 . "$

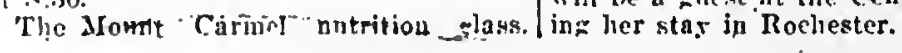
as physician was next visited. It was fom:d that a number of chjldren had marle cxcoilent falias aul. that sereral were nea eradiation. All - children is the class have given up tea nud coffee and uiany are drinking nilli. 'The hichin. est gain in the class was three pounds. hint the best eliart in the cluss is owped lip Toseph Mirulelln, who has made n steady gain rach wrek and hiss a good elanee of going over the top in sunther week. This is a ease whare the chill] was more than 10 per eent. under n'viplit.

Miss skilton ranarkel that the children in the class looked lirtter wad held thmmselves better than when thes entcrol, and some of the children had made such a gain that she scarcely recosuized tham. Niss Skilton impressed mpon thr "hillien that "now is the time to stom." If linder-Weiglut modition persints it hernmes rluonic nod is harder to corrert in later lifi. Chilitren taken io the enrly renrs if life enn gain their weigbt much nicre readily and owce gained, if no. plysical defoets are yresent. the weight will not he lnst. Gracluates from nutrition classes. nccording to Miss Skilton, do not tend to lapse:

Miss Skilton is in the cits under the allspices of the Tuberculosis Association of Iiochester and IInnoe County and will be a gltest nt the Century Club clur. 
FIGURE 6.

Newspaper Article-C.

\section{The Public Schools \\ What Schools Have Done, Are Doing. and Will Do for Buffalo.}

\section{WASTING $\underset{\text { LIV IVES }}{\text { Wut }}$}

Ye editor has no head for figures and no inelination to make figures lie. Statisties are inconvenlent to get and dry reading anyway, so we shall
dispense with them and base our story on facts that you, kind reader,
only to look around you to verify.

Here look around you to veriey:

Eabies are born every minute many of tiem well and strong. many of then cursed with a heritagc of disease; - for "The Sins of the Parents Are Visited upon their children"-even to . the third and foivth generation." (2) At the enc of a year lilies are bowing over a multitude of little graves where the proud faces of mothers might

(3) In two years there are many more little mounds in God's acre and many more empty hearted mothers in many more

(4) In three years most of the weak (7) Sut there are still many of our bables left. By this time they are in school, thousands of them-selected group that has survived the ordeals of infaney and early chlidhood; aurely these shall develop to strong, sturdy manhood and womanhood. Let us see A Glimpse of the Schoolronm. (8) Let's' look in on average fourth or fifth or sixth grades-not as phy. siclans or nurses but just as parents with our eyes onen. Five pupils wearing glasses. Why? That's another story; but they show parental attenion and mentally we give father a pius mark. Five more frowning or bend. Ing over books, some with red eyeilds and inftamed eyes-the frowns are not from displeasure nor the eves red with anger. It's eye straln. What eauses it? Why isn't the cause removed and the condttion corrected? Some one is blundering and the ehild littie voices are never more to be is paying for the blunder. Over in the
heard on earth and, alas! many of the corner-a vacant face, parted lips, pale, heard on earth and, alas! many ou say round shouldered, a typical "mouth"God has talken them," "the Lord breather." Why?" Why doesn't some giveth and the Lord taketh away." one throw out the life-line to this cinila And here permit a passing comment. before it's too late?

The Lord gave the iittle child. True, Mriddic row-halfway back-pale lit and the Lord hath taken it baek. True tic girl, narrow ehested, with dreamy again but we are not so saeriligious as eyes too hright if disease has bezun, to belleve that the Lord was on "In - too dull if poor nutrition has not gone to believe "and that He would jeal- tnd far. A eandidate for the npen air dian Giver and that or cruelly take cliss or the tubereulous pard. Yaur ously or wantonly or cruelly take chrss or the tubereulous ward inur away what He had given. Why not rhrice now, later there will be no God had taken back the little soul because we saerificed the little body upon the altar of sin and ignorance or negleet. Jet elean, wiae, thoughtful parents who lose' a little child take God had use in heaven for:the iittle God had use in heuld be no such comone; for the father who defiled his body or the mother who became a body or the mother who became a that the buby should have. Much less excuse or comfort should there be for parents who ignore their charge or delegate their parental duties to servants. say? Not at all, we are merely saying again what science admits and religion shouid admit if its doesn't, that: CHJLD MORTALITY IS THE DIS grace because

'T IS PREVFNTABLE.

sut to resume our arraignment of facts (5) In four years the fittest children of the fittest parents have survived; also some born weak and some who have had weakness thrist upone them.

(6) Now comes the time whun (6) Now comes the time whin childhood runs the gruntlet of "Chll-।
dren's diseases." Mumps, measles, dren's diphtheria, whooping cougi and scarlet lever, ald the grim reaper to take toll of our little ones. For we have raised no fortifications against himhave put no barriers before him. Like Indian faltalists our cry 18 "Kismet" or weakly call upon our faith instead of

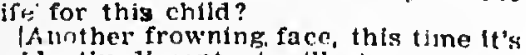
cvidcutiy discantent, III temper-not cyes-a misfit in the class. He veeds sininthing to do that hn can do-hand worli, book work, thist is practical. He's the opportunity Rohanl type. but he sn't in the opmrtuntfy schos here isn': ennugh fnom for him. What's the answer? More npportanity arger than that we now have.

$A$ stolid face in the hack scat atrricts our attention. "Vory slow, never recites-deaf." A tragedy in five words. The answer: Special class with special attention, lip reading. deaf un to you, Mr. Taxpayer. By the way, how much is a child's life worth, anyway?

Turn to the Weight Chart.

We turn to a chert on the wall. It's story is told in fisures that do riot lie. for they are the reenrd of the seale which is ar instrument of jorecisium And the story of the seale as seco:-ded on the chart is that one chlid out of on the che th the overy five is below "the riegight that his helght demands. "Thiat's the caupe?" trition?" Bad food. What's the result? I refer you to a medical diet lonary, be gin almost anywhere and read both

Penple of Buffalo, these rather $1: \eta$ pleasant striles have only one pure. nose. To enliat ynu in an army ths. shall fight intelligenlly for the presar. -ation and welfare of our childrer.

Inw snon shall vou be really or the inw snon shat 
The five newspaper articles which follow are not assigned a definite position on the scale. Their relative position has been given.

FIGURE 7.

Newspaper Article-H.

\title{
School Health Workers Call 5-Cent Milk High
}

\author{
Hygiene Committee Chairman Seeking Means To Secure \\ Nourishment For Children At Cheapest Possible Cost \\ Asks Aid Of Dr. Buckler In Formulating Plan.
}

The hygicne committce of the School, paid only 3 cents a half-piat, and that Boand, to which the question of extending the milk service in the schools was referred by the board, appealed today to Dr. Warrea H. Buckler, director of health work in the schools, for a plan whereby this tould be accomplished.

Theodere E. Straus, chairman of the committec, snid there is a fund of about $\$ 1,000$ which bad beca provided for school luncheons which might be arailable for such work. It is felt that the price of 5 cents a balf-pint, whlch was quoted by the Baltimore Dairy Councll to the School Board is their offer to sell milk at that price to the schools aod to pply children who could not afford to y, was too high. In Dr. IYenry S. West's report to tho School Toard untlining the present system of sprving enilk, it was pointed onl that at School No. B, the ouls school where rocres ehild drlnks his half pint of milk dails the children

at School No. 39 milk w88 sold at "4 cents a half-piat. It is declared that the childrea be provided milk at whole sale price.

Council is interested.

At the Baltimore Dairy Council it was stated tliat the propositjon to extend the milk service in the schools had nroused much interesit among the teachcrs. Ninetecn schools hare asked for further information on the sabject and Indicated that the service wonld be wel. comed if the School Board asteed.

Opportunity for Miss Sophis Seyferth, teacher at the Eastern - High School, who complained to the board yestenday that she had becn discriminated against in the matter of salary, to be examined by the board's pliysicino, will be granted immediately. She was ranted a leave of absence on balf-pas until April 1, with the pripllege of returning to her classroom if able before that time. 
FIGURE 8.

Newspaper Article-E.

\section{CHILD'S WEIGHT IMPORTANT}

Undernourished One Is at Disadvantage, Herman J. Norton Shows.

"A child who is 10 yer sent, or more inuler weiglit ennnot be expected to prograes as irapidly: and 'sucecessfully in ixehool as " clllid nho is, 1np to nomal." sail Hermun J. Norton. director of ply. sical chlucation of the Board of bducn. inn. in snenkiug before the Ieagile of iNomen Votery at No. 104. West avenue last evening.

"iutrition classass have already heen restublishel in oome of the pinblic xchool anl the hupe before long to bp, ahle "il conduct claswes in. nill of the schools. The resuits olutuined to fai have been re imarkable. It is surprising to sep the number of chllliten who are really suf. ferln:- from malnutrition."

Mr. Norton iflustrated Wa talk witi alides prengied hy lr. William R. It Emerson, of Baston, who "Nas lirnilyht to this citr recently wy the Tubericulosis Assoclation, and who started the classed. Ir. Nopton will give talks to: nther or zonlentions thint desire to learn nure al his phase of liealtli mineation iroik. 
FIGURE 9.

Newspaper Article-J.

\section{MEAL COURSE HELPS UNDERWECGHT GRLS \\ Masten High School Pupils \\ Drink Milk, Eat Graham Biscuits Daily.}

War has been declared on undermourishment at Masten Park High school. Under the leadership of Mary Krieg, in charge of physical training. more than 100 rirls all underircight. are taking the "meal courge" and are are taking the "meal

gaining in avoirdupois.
This course was begun last fall under This course was begun last fall under now on a leave of absence in New York. Last term 103 took the crurs. Most of them come from comfortable homes where they can eat plenty of food, but sometimes they do not cat food, but sometimes they do not cat enough of the right kind of food and
this shows in their wright and general nealth.

Unlike any other course in the high schnol, there are no credits or no homs. work in 'this. When a gir! is found underweinht all that is required of her is that fivery morning at 9:45 her is that ficery morning at $9: 45$
o'clock, after rerigtering. slic shall drink a plass of milk and eat a ETaham biscuit.

Department records show how beneficial this sinnle regimen ins proved. Nearly all thr girls hoth last term and this: have calned in wichi.

Teachers also improse on the firis Teachers also improse on the firis plents of sleen, the proper kinds and quartities of foorl and otber riat:ers nf hyzicre.

"Sometimes tre have trouble tritt. urls" said II ten Tlackman. who as 6urls. Maia most rarnot Firls are delighted with this ince. Thg heliful to us." 
FIGURE. 10

N5CHEILDAEN

Newspaper Article-A.

mattc: " come betore the Cormall $M r$. arcetic

$\because: d$ pointed nut tilat ...c be bullding would cling. Inale a thogo a year reut blll and that $\$ 450.000$ could be ohtained to-

$\$ 95,000$ Rlanned by School ward the payment of the bullating

\section{Board To Feed Under- noürished Pupils.} tion property at 50 Broadway.

BLDGET Is CONSIDERTí.

The board of educallori. meeting as in commlttee of the wholc, hegan the conslderation of ur: school As result of two reporis to the budget yesterday. The gross ask. board of educatlon, onc showing Ings of the malntenance fund werc that there are 3,000 dangerously $\$ 13,2 \$ 3,253.43$. Some of the importundernourished scisool childicn lis ant tems going io make pp this tic city, and tlic other showling that sur arb $\$ 5,373.734$ for the clemen$20 \mathrm{pcr}$ ccut of the school children in surg arb $\$ 5,373.734$ for the clementhrce representative districts are schools; $\$ 309,334$ for the internedl. unclernourished, the school board ate schools; $\$ 518,004$ for speclal ed. budget committec Tucsday declded ucation, Including the crippled, blind, to ask tentatively for a $\$ 95,000$ ap. deat and anaeinic children.

on to ac proprlation to supplcment the leed-commodatc 70 children each weri) ing of these chillien in a scientifle requeated. Next year it is estlmated waỳ for onc ycar.

that the board will Instruct 510 "ay for onc ycar. ash 10 supply lunches for 3,000 of speech. The estimate for incorr. the undernourished chllaren: the glbles is 359 and for backrard rest of the money would care for chlldren, 2,165 .

the huard's appropriation for meals The budget ahowed an increase of for the anemic chlldren, the deaf, 7 per cont in educatlonel admin. the parental school and other rcgu- istration. This increase is due to ia actlvitles of past years. The the vocallonal bureau, the ache to $\$ 95.000$ is purely tentative and will the vocallonal bureau, the schedule bc revised when the complete re- of new clerks to relleve executivee sults of the health survcy now be- of new clerks to relleve executree

ing taken in the schools is made and addltlons to the the Junclies furnished In the ochools will be asked to do so. Samuel C. will be dsked to do so, Samuerd, board member, sald.

go prR CENT UNDERNOURIgHED. upplementary estimate for fec..... undernourished chlldren will be consiclered in a week or 10 ays. A department of health sur. hla

by of the city according to Dr. Froviston is nudc in por the coacining of forclgners bj ioner showed the number of an asslgnine 10 coalching teachers fo sioner, showed the number of dan- this purpose.

gerously undernourished. Mr. Mum. $\Lambda$ grow... of 30 per ecnt wat ford told the board that a. survey shown in the suminer clementars made in tlirec difterent types of dis-schools and nembers of the boar? made in thed dif ihildren were undernourished. This pedited progress and telsded to wildren were undernourished. This pedited progress and tellded to. was truc even among children of "rords the sll ycar aridid school. all the children in the city would . S fanttors salaries werc consid. be weighed and measured to de.ered. but no actiontaken. $A$ s5 in. comine how wespread the under. crcasc was granicr as a bonus $t$ terme englneers in 1919 and 1900 gn ing study would be made.

a i jolnt meeting of the boal the engineers in 1919 a nd 1920 , gne the board committee sisgzested that now as living conditlons were mor normal, the cnginecrs salaries sion Tuesday it was derided to rc. might bo quest the Common Council to lease a month.

the property on the prosent down. The board, neeting as a commit the proper. town lihrainesda at bullatis a joint bard or couca. At that time or at the reger tion administration building ani laon. At that time or at the regid

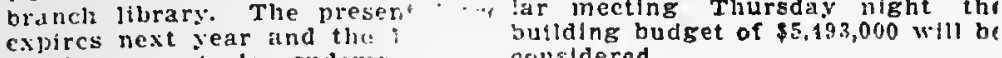
on the property is "owsicm

\section{Feeding Undernourished \\ ne by Women's Clubs}

a mecting of the clitld welfare artmenl of the Tederailon of peration of fints juarning the co tendent of schools. F. Vaughan, health comnilssioner. in the department's proposed plan for the department's proposed plan for

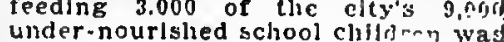
Indorised.

"Tlie plan is not a new 01 . , o the clild welfare departiment," sald Mrs. iw. H. Mortimes, chalrmar. "For three years the women's clubs of thls clty have fosicred the ldes that the work we have liecn dolng would win the recosnltion of boti thio departiment of licalth and tlic Lio department of
Loard of cducation.

\section{ASKED CODT'B AID.}

"II a recent letter to . Ar Cody" wis asked co-operation in this work. which it was our.intention to carry in in larger proportions. Tho result. has bsen so bencfictal anci satisfa:tool of parenta so apparent that the fedcration hoped"to cariry its worl. ir: to cvery school of the cliy.

"The department, howcver, is not entircly in tavor of the plan out. lincd by Dr. Vaushan, which lecommends that the hot meals be fiven frec to theso chlldrell. one of the alms of thils depariment is to ciscourage the pauperlzing of DCtrolt's cltizens, and we helleve that this would be an outgrantl of a free luncli plan. Lunches should be liald for by parents whis are able to do so and only thosn chlldren whosi honje conditions found whosi honle conditions irc found umsigned to the casc shouid be glven assigned to the
meais gratis."

MRs, Novak' TExpLAINs.

Mtrg. Charles M. Norak of tho fedcratlon nolnted out that the cinlld velfare department has ucen serving lunches of milk and crackers for the past threc years in 20 of the clty's schools. More than 5.000 children benented by this food which is aerved each day at $10 \mathrm{a}$. $\mathrm{m}$.

The monthly reporta given out this mornlng by members of the committee showed that during the 17 school days of December, $\$ 1500$ had been pald for mllk and crackers. Pennlea collected from chlldren able to pay amounted to $\$ 1,38$. The deficit was made up from the John Dodge fund whlch was given for thls work several montlis ago. incrcase In health and welght of the chlldren partaking of thesc luaches was in great contrast to schools where no lunches were served diur. ine he month, according to Mlrs. Morimer. 
FIGURE 11.

Newspaper Article-D.

\section{FOUND FIVE HUNDRED SCHOOL CHILDREN IN NASHUA SUFFERING FROM MALNUTRITLON CAUSES}

\section{Dr. Wallace of That City, Gives Important Address on Survey Results at Durham Farm Bureau Meeting}

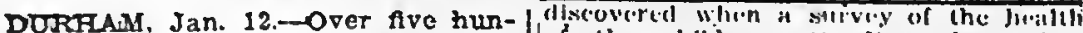
dred school children in the city of Nasbua betwicen the kindergarten age and the juntor bigh school are under weight, stated Dr. Arthur Wallace of the Gate City, the only formal address of the day, on sccond day of the sixth annoal New Hampshtrc Farm sald that similar conditions to those in Nashua and clsewhere are a mell:A.cc to the elate and the nation and rurecsted the desirability of pasoting irepislation that will makic it imposislik for boys and birls suffering hora the indilnulvition and its consequencthe indi-nuti: obtain conplosment in factories rutlls or clsewherc.

Hinders Growth.

The te' and coffec habith which hinders the srowth of the tissues in chlidren. is all too prevalent," deliarcd Dr. Wallace and added "Over in nor cost of the children in Nashua we is and coffee ditnkers"

Doplotion the starline conditions

\section{SUFFERING}

(Continued from Pagc Onc.)

Wallace, wero first, bad tonslis and adenolds; second, bad tceth; third, exccssive fatigue: fourtin, insuficicat food: fifth. bad habits of living

Many defects.

Examination of the children. Dr. Wallace sald, showed that prictlcally

of the chlldren uttending the public schools of Nashum was made Dr. Wal. ince aad it hols found that only 2 ? per cent of the children were accus. tomed to drink milk. "During this survey". said Dr." Wallace, "It waa dis. civvered that 95 pupils ont of 248 cxamined especially to discover mal nutritlon were underweight. You will mitritlon were underwelght. You u'il readily see that that is simost 40 per ent."

Determined to prosecute the cani. palgn of education and to try and correct the serlous conditlons found, is well as secure the co-operation of the parente of - school children, those in charge of the ourvey adopted the wiogan."We belleve that slogan, "We belleve that heaith la more Theducation alone.

The results of the campalgn dis: closed five causes which contributed tc the deplorable health conditions ex. isting among the Nashua school chil. dren. These five calsses, declarcd Dr (Continuted on Pnus Thret.)

cvery cásé midntested such symptoms as curvaturo of " the salne syms muscles, stooped thisuliere a baggcred, sobcr cxpression. Dr. Wallace relared ?n detall low" the survey committce has bien worls-

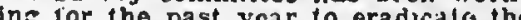
ing for tho jast ycar to eradicals the causcy of malnutrition discovered alnons the Nashua shituren. He ssid that id systein of catcationni traintns to Icilch tho parents and the.children how to co-operate in climinatlug the deplorablo coipsequences of mainutri. tion has been inausurated and Ifls systcm has already sliown much resuits.

Actual fecding in some of the cchools ras been attempted and the drinking of cocos and mllk in licu of the all ton prevalent use of tea and coffoe bas beca porsistently encouraged.

Dr. Waliace intimatcd that Nashua is Dr. Waliace intimated that Nashua is
ot the only. community in which schoo villdren are suffering from malnutr. tion and $\mathrm{its}$ bad efrects, ajd let the $\mathrm{Im}$. pression on the sudlence that of stmilar carceully conducted survey will reveal approximately the sume condition in hnv urban or fural community. 
TABLE XXII.

MEDIAN RANKINGS GIVEN TO TEN NEWSPAPER ARTICLES BY TEN GROUPS OF JUDGES

Read the Tables as follows: Of 85 School Administrators, one half placed on Article A, a value less than 4.1 and one half placed on Article A, a value greater than 4.1.

\begin{tabular}{|c|c|c|c|c|c|c|c|c|c|c|c|}
\hline \multirow{2}{*}{ Groups } & \multirow{2}{*}{ Number of Judges } & \multicolumn{10}{|c|}{ Median Ranking Given to Each Sample } \\
\hline & & A & B & $\mathrm{C}$ & $\mathrm{D}$ & $\mathbf{E}$ & $\mathbf{F}$ & G & $\mathbf{H}$ & $I$ & $\mathbf{J}$ \\
\hline 1. School Administrators & 85 & 4.1 & 3.3 & 1. & 3.3 & 6.6 & 7.4 & 10. & 6.9 & 5.5 & 5.3 \\
\hline 2. High School Principals & 87 & 4.1 & 3.9 & 1.3 & 2.9 & 7.6 & 7.3 & 9.8 & 6.5 & 5.7 & 5.4 \\
\hline 3. School Teachers & 61 & 4.4 & 3. & 1.4 & 3.1 & 7. & 7.8 & 9.7 & 7.5 & 5.6 & 5. \\
\hline 4. Advertising Women & 34 & 1.3 & $\mathbf{3 . 3}$ & 4.3 & 3.6 & 5.4 & 8.4 & 9.8 & 5.5 & 6. & 5.6 \\
\hline 5. Housewives & 37 & 4.6 & 3.7 & 1.3 & 3.8 & 6. & 8.1 & 9.8 & 7.4 & 5.9 & 5.1 \\
\hline 6. Persons in Professions & 34 & 2.5 & 4.1 & 1.5 & 3.4 & 7.2 & 8.2 & 9.7 & 7.5 & 5.1 & 5.7 \\
\hline 7. Persons in Business & 24 & 3. & 3.5 & 1.4 & 4.5 & 7.1 & 7. & 9.8 & 7.5 & 5.2 & 5.5 \\
\hline 8. Clerical Workers & 12 & 4. & 3.8 & 1.4 & 3.2 & 6.5 & 7.5 & 9.7 & 8.5 & 3. & 5.2 \\
\hline 9. Artisans and Laborers & 24 & 4.5 & 4.5 & 1.5 & 3.1 & 6.8 & 7.8 & 9.2 & 6.5 & 4.1 & 5.8 \\
\hline 10. Newspapers Workers & 5 & 3.3 & 5.8 & 8. & 2.3 & 6. & 4.3 & 9.9 & 5.3 & 5.2 & 4. \\
\hline
\end{tabular}

TABLE XXIII.

THE NUMBER OF “BETTER”. JUDGMENTS OF ${ }_{3} 69$ INDIVIDUALS IN RANKING THE TEN ARTICLES

\begin{tabular}{|c|c|c|c|c|c|c|c|c|c|}
\hline \multirow{2}{*}{$\begin{array}{c}\text { Articles } \\
\text { Compared }\end{array}$} & \multicolumn{9}{|c|}{ Articles with which comparison is made } \\
\hline & $\mathbf{F}$ & $\mathbf{H}$ & $\mathbf{E}$ & I & $\mathbf{J}$ & $A^{\circ}$ & B & D & C \\
\hline G & 86 & 73 & 60 & 35 & & & & & \\
\hline $\mathbf{F}$ & & 174 & 239 & 102 & 71 & & & & \\
\hline H & & & 208 & 119 & 100 & 94 & & & \\
\hline $\mathbf{E}$ & & & & 134 & 116 & 82 & & & \\
\hline I & & & & & 182 & 137 & 103 & & \\
\hline $\mathbf{J}$ & & & & & & 137 & 107 & 116 & \\
\hline$A$ & & & & & & & 171 & 144 & 99 \\
\hline $\mathbf{B}$ & & & & & & & & 164 & 89 \\
\hline $\mathbf{D}$ & & & & & & & & & 100 \\
\hline C & & & & & & & & & \\
\hline
\end{tabular}

Read the table as follows: 86 of the 369 individuals considered Article G "better" than Article F; 73 considered Article G "better" than Article H; 174 considered Article F "better" than Article H; etc. 
TABLE XXIV.

THE NUMBER OF "BETTER" JUDGMENTS GIVEN IN TABLE XXIII REDUCED TO PERCENTS OF THE TOTAL NUMBER OF JUDGMENTS

For the method of reading this table see Table XXIII.

\begin{tabular}{|c|c|c|c|c|c|c|c|c|c|}
\hline \multirow{2}{*}{$\begin{array}{l}\text { Articles } \\
\text { Compared }\end{array}$} & \multicolumn{9}{|c|}{ Articles with which comparison is made } \\
\hline & $\mathrm{F}$ & $\mathrm{H}$ & $\mathbf{E}$ & I & $\mathbf{J}$ & A & $\mathrm{B}$ & $D$ & $\mathrm{C}$ \\
\hline G & 23.3 & 19.3 & 16.3 & 9.5 & & & & & \\
\hline $\mathbf{F}$ & & 47.2 & 35.2 & 27.6 & 19.2 & & & & \\
\hline $\mathbf{H}$ & & & 43.6 & 32.2 & 27.1 & 25.4 & & & \\
\hline $\mathbf{E}$ & & & & 36.3 & 31.4 & 15.5 & & & \\
\hline I & & & & & 49.3 & 37.1 & 27.9 & & \\
\hline $\mathbf{J}$ & & & & & & 37.1 & 29. & 31.4 & \\
\hline A & & & & & & & 46.3 & 39. & 26.8 \\
\hline B & & & & & & & & 44.4 & 24.1 \\
\hline $\mathrm{D}$ & & & & & & & & & 27.1 \\
\hline C & & & & & & & & & \\
\hline
\end{tabular}

TABLE XXV.

THE DIFFERENCE BETWEEN THE VARIOUS ARTICLES IN THE SET OF TEN DERIVED FROM THE PERCENTS OF “BETTER" JUDGMENTS GIVEN IN TABLE XXIV AND EX-

PRESSED IN TERMS OF THE DIFFERENCE WHICH EXACTLY SEVENTY-FIVE PERCENT OF THE JUDGES ARE ABLE TO DISTINGUISH

\begin{tabular}{|c|c|c|c|c|c|c|c|c|c|}
\hline \multirow{2}{*}{$\begin{array}{l}\text { Articles } \\
\text { Compared }\end{array}$} & \multicolumn{9}{|c|}{ Articles with which comparison is made } \\
\hline & $\mathrm{F}$ & H & $\mathrm{E}$ & I & $\mathbf{J}$ & A & B & $\mathrm{D}$ & $\mathrm{C}$ \\
\hline G & 1.09 & 1.26 & 1.45 & 1.95 & & & & & \\
\hline $\mathrm{F}$ & & .10 & .56 & .88 & 1.29 & & & & \\
\hline $\mathrm{H}$ & & & .24 & .68 & .91 & .98 & & & \\
\hline $\mathrm{E}$ & & & & .52 & .72 & 1.51 & & & \\
\hline I & & & & & .03 & .49 & .87 & & \\
\hline$J$ & & & & & & .49 & .82 & .74 & \\
\hline A & & & & & & & .14 & .41 & .92 \\
\hline B & & & & & & & & .21 & 1.05 \\
\hline D & & & & & & & & & .81 \\
\hline $\mathrm{C}$ & & & & & & & & & \\
\hline
\end{tabular}


TAE BEATTLE BUNDAY TISTSS SEPTEMBER S, I96O.

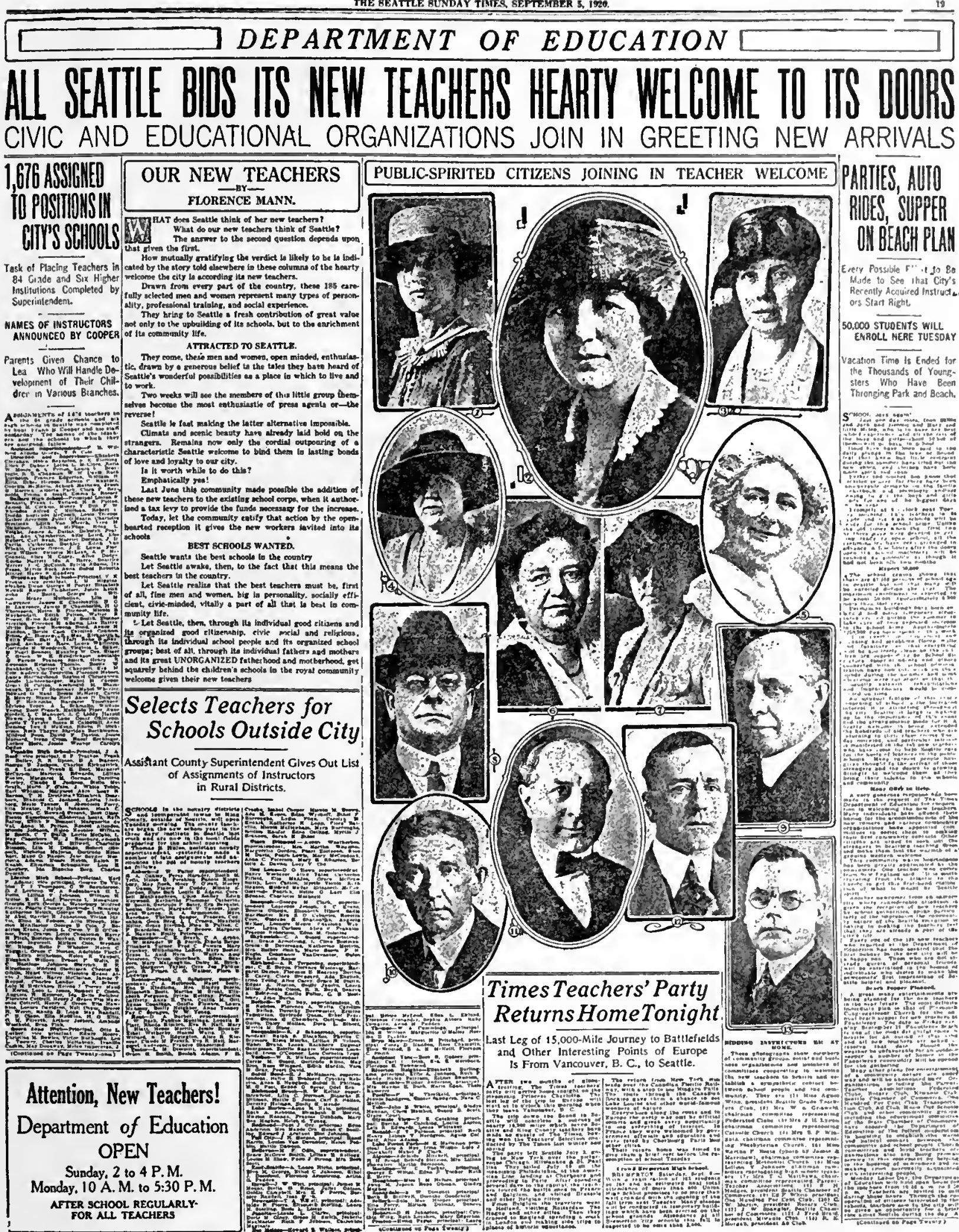

A SCHOOL PAGE FROM A CITY WITH A SCHOOL NEWS PROGRAM 


\section{CHAPTER VI}

\section{A PROGRAM FOR SCHOOL INFORMATION SERVICE IN THE DAILY NEWSPAPER}

The suggestions set forth in this chapter are general. School administrators will find that the size of their system, the attitude of the newspapers, the policy of the board of education, and many other factors enter into any school publicity program.

\section{TWO KINDS OF SCHOOL PUBLICITY}

First of all a distinction should be made between two kinds of school publicity.

I. Special purpose publicity carried on for the purpose of achieving some immediate end. Bond issue campaigns, teachers' salaries campaigns, and the like.

2. Continuous informational news service. By this is meant the constant publication of informational material about the school system. This service has two purposes: (a) The discharge of the obligation, on the part of those responsible for the public school system, to render a report of its activities; $(b)$ The creating of "good will" on the part of the community's citizens in order that their support of and cooperation with the public school system may be based upon full information.

It is not the purpose of this study to deal with special purpose publicity. It has been mentioned as one type which school systems at times must use. It is the type which is most commonly thought of in connection with public schools. Considerable study has been given to this kind of publicity, and the facts are available. ${ }^{1}$ Figures I 2 and 22, pages 98 and I 8 show examples of newspaper publicity for special purposes.

The suggestions in this chapter deal entirely with continuous school news service.

\section{THE ORGANIZATION}

School news service should be carefully organized. It should be recognized as an important function of the public school system. The same care that is used in organizing any other administrative division should be used in organizing news service. Haphazard or

\footnotetext{
'Alexander and Theisen-Publicity Campaigas for Better School Support.
} 
accidental news preparation and publication will not accomplish the $A$ Program results desired. There are two types of organization.

I. A Centralized Organization:

This type is a division of the administration of the school system. It heads up in the office of the superintendent of schools. It may be directed in various ways.

(a) By a news or publicity director whose duties consist in the preparation, manufacture, and distribution of all printed material used by the school system. School news service in the press will be one of the duties which he directs.

(b) By the superintendent of schools who may direct this activity as one of his administrative duties.

(c) By some other administrative officer,-an assistant superintendent, a supervisor, the clerk of the school board, etc., who may be assigned the direction of school news service in addition to other duties.

(d) By some principal, special instructor, or teacher, whose other duties are so arranged as to allow time for the direction of school news service.

This director of news service should probably have an advisory board or cabinet, representative of the administration and of the teaching staff. It is possible that the children, patrons and organizations closely allied to the school system should be represented in this advisory body.

\section{A Representative Organization:}

This type of organization will be headed up by a School News Committee. This committee may be made up in various ways. It may represent the various departments of the school system, such as Elementary Education, Vocational Education, etc. It may represent the various schools in the system. The local school situation will determine best how it should be made up. Such an organization gives to the teaching staff an opportunity to share in one of the administrative responsibilities of the school system.

In this representative news committee, the administrative department, the teaching staff, and possibly the student body and patrons of the school system, should be represented. 


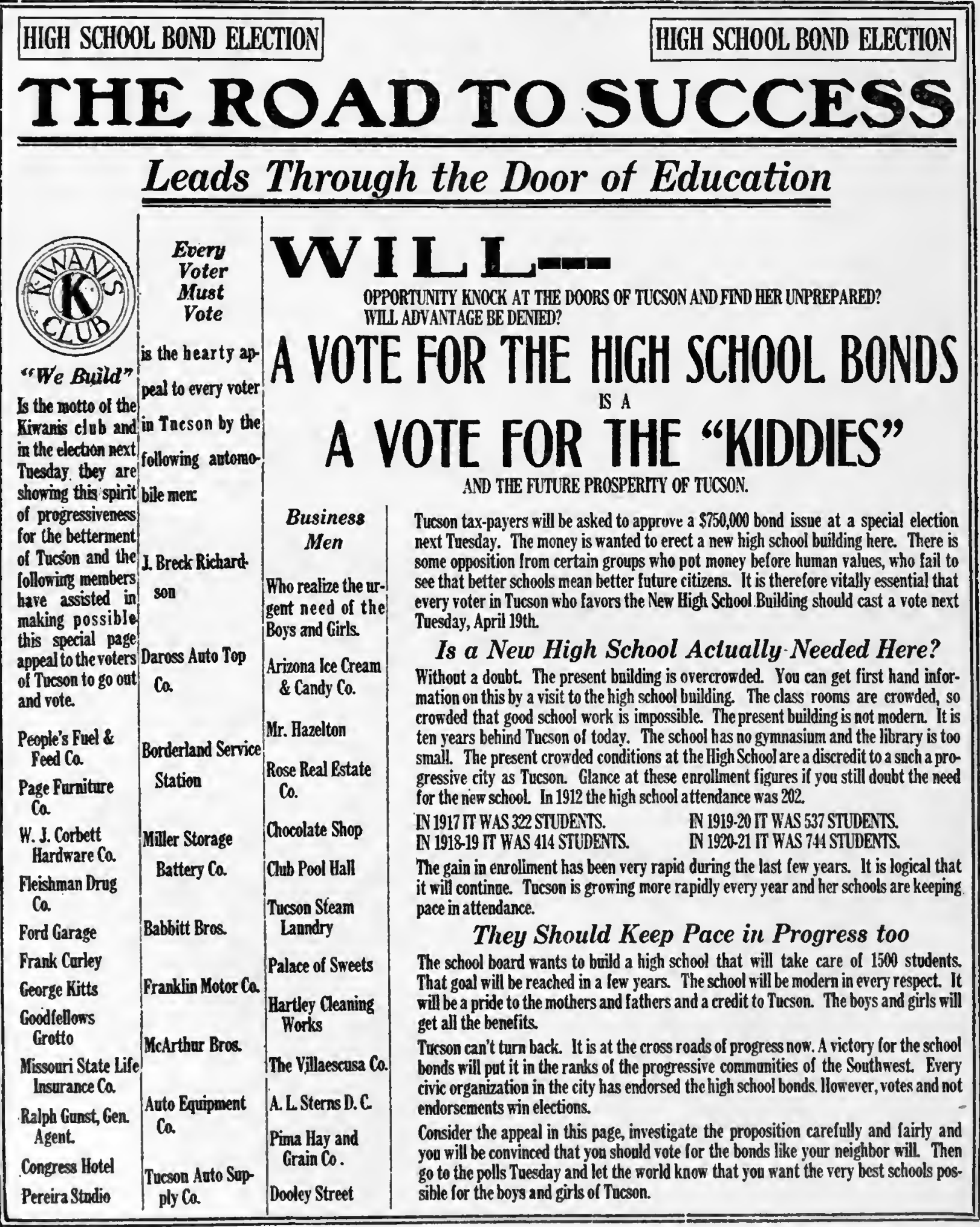


THE FINANCING OF SCHOOL NEWS SERVICE

In most cases, the financing of school publicity is a matter for A Program school board consideration. So far as newspaper service is con-for School cerned, it is probable that little financial backing is necessary. If News. school news is of the right sort, the newspapers will, in most cases, gladly print it at no cost to the system. Where funds are necessary to carry on publicity activities, they must be secured from a school board which has been convinced that the expenditure is justified, or they must be secured from individuals or organizations interested in this kind of school activity.

\section{THE COLLECTION OF SCHOOL NEWS}

The organization of this part of the publicity process will vary greatly.

\section{Units for News Collection:}

Some of the units possible for the collection of the news material are as follows:

(a) The whole school system, with news collectors assigned to pick up news wherever and whenever found.

(b) The various administrative divisions, with one news collector responsible for covering all news that deals with the Buildings and Grounds Department, the Department of Research, etc.

(c) The various teaching divisions into which the system is divided, with collectors responsible for news relating to Kindergarten Education, High School Education, Vocational Education, Athletics, Student Activities, and the like.

(d) The individual schools or buildings, with one collector responsible for all news material relating to the activities of any one school or building.

2. The News Collectors:

These are the school system's reporters. They can be selected from the following:

A news director.

Superintendent of schools.

Clerk of the school board.

Supervisors.

Principals.
Individual students.

Individual teachers.

English classes.

Journalism classes. 
Music Training Recognized in Great Falls Schools as Aid in Development of Alertness, Initiative and Precision
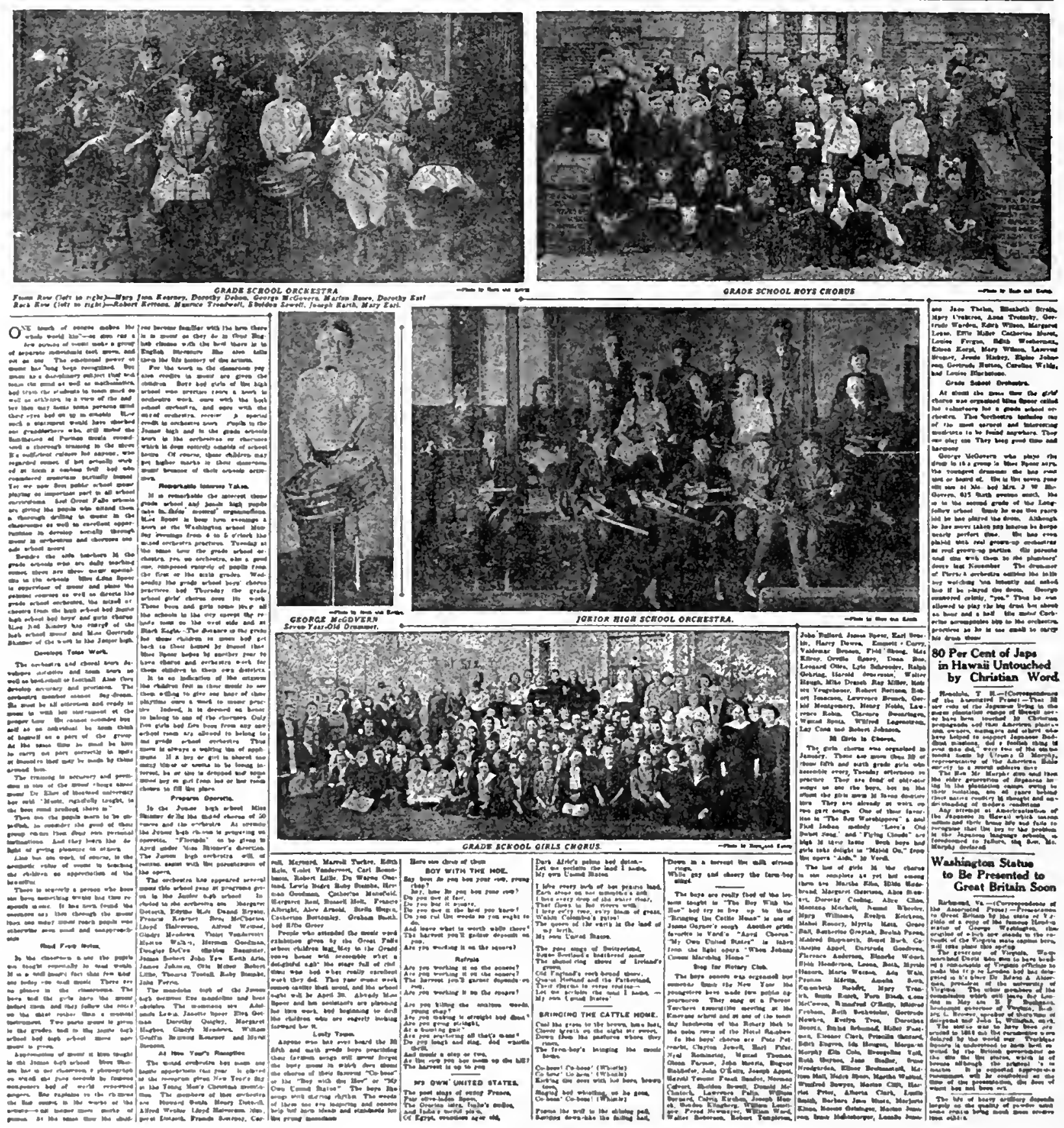
The type of organization will determine to some degree which $A$ Program of these agencies shall be used. Facts presented in pre- for School vious chapters show that students are to a considerable News. extent being utilized for this purpose.

\section{The Editing and Approving of News Collected:}

School news for newspaper publication should be edited. It will be edited by the newspaper. It should be edited by some one in the publicity organization of the school system. Such skilled editing will save labor and trouble for the newspaper and, more important still, it will make for less of error and mis-statement. News copy prepared by school systems and printed in the newspaper is evidence of the lack of proper editing based on a knowledge of good newspaper style. The type of organization for handling school news will to some extent determine the method of editing. If the organization is highly centralized, the editing will necessarily be done by some central agency. If the organization is more representative, the responsibility of editing school news will probably be scattered among various persons. At the present time, the editing of school news is done by the following:

News director.

Superintendent of schools.

Principals.

Teachers.

Athletic coach.

English or journalism classes.

Student editors.

In many cases, the only editing which school news receives is done by the newspaper organization. Some school people reporting on this subject expressed an opinion that in some cases the editing of news in the school system, especially by a central authority, might become censorship and that anything resembling this would be contrary to democratic ideals. This point is undoubtedly worthy of thought. It should be possible, however, to give to news prepared within the school system the benefit of editing without subjecting it to the evils of censorship. Much harm has been done to the cause of public school education by the unedited newspaper productions of irresponsible correspondents. 
FRIDAY, FEBRUARY 18, 1921.

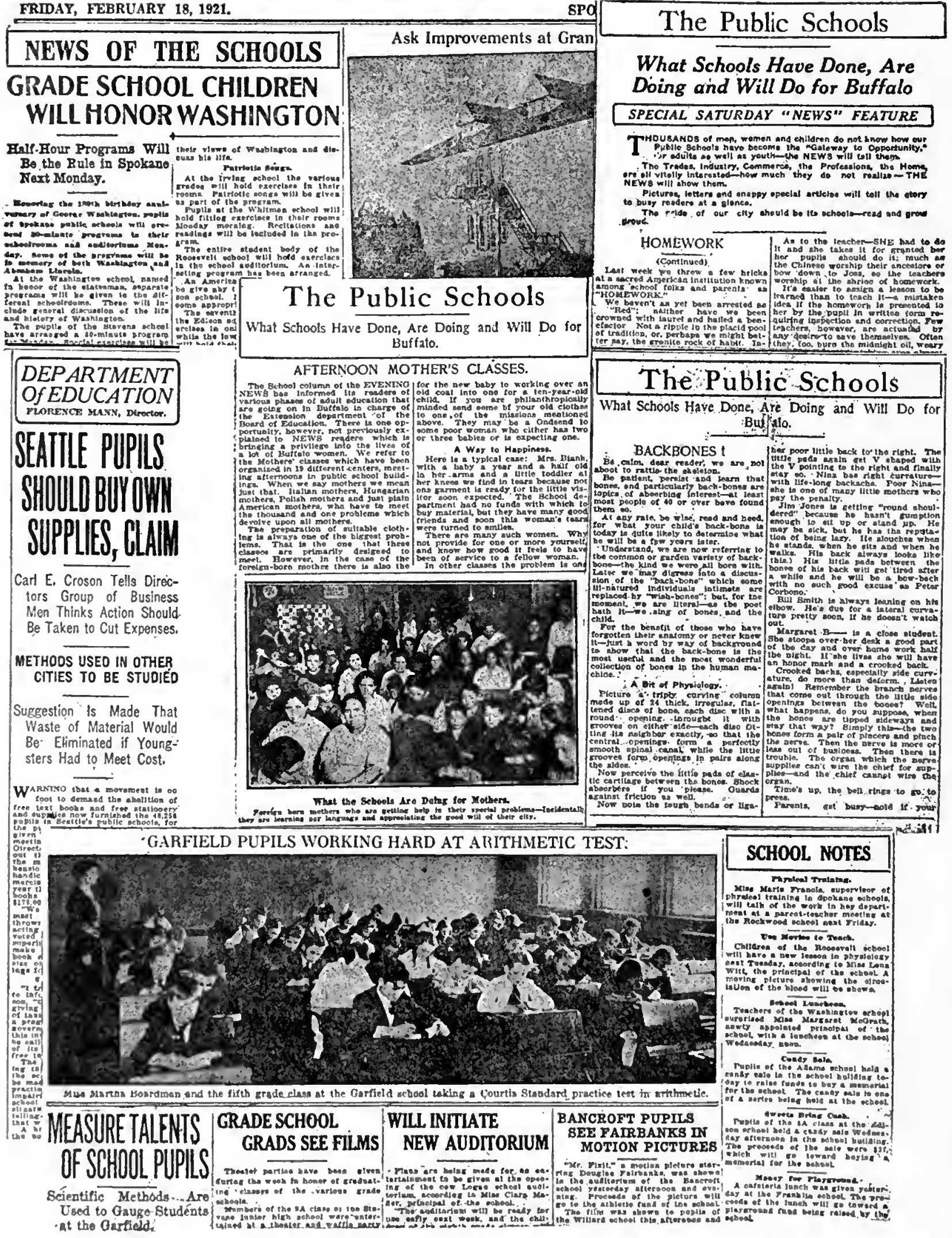

THE, SCHOOL COLUMN OR NOTES 


\section{THE DELIVERY OF SCHOOL NEWS}

Provision should be made in any school news organization for the A Program delivery of school news. One of the most common criticisms of for School editors is in relation to this matter of delivery. The guiding prin- News. ciple is, that the value of school news, to a very great extent, depends upon its timeliness. Therefore, an efficient school news service will provide for the prompt delivery of all news as soon after its happening as possible. Some newspaper editors state that all news should be collected in some central office, that it may all be available to the newspapers. Again the type of organization will determine the method of delivery. It can be assembled promptly and delivered by one central agency, or each division or school can be held responsible for the direct delivery to the newspaper organization.

However it may be collected the all important element of timeliness which is the chief characteristic of daily newspaper articles must be observed.

\section{RELATIONS OF THE SCHOOL NEWS ORGANIZATION WITH THE NEWS- PAPER ORGANIZATION}

I. Personal Relations.

School news in the daily newspaper cannot be carried on successfully without the cooperation of the newspaper organization. Therefore one of the first essentials in any publicity program is the sympathetic cooperation of school and newspaper. This should be based upon friendly relations and a mutual understanding of the problems of each. The personal touch is necessary. This personal friendship is not to be construed as a means of influencing newspaper organizations or in any way attempting to control what school news shall appear in the press, but it is the only basis of a proper understanding between the two institutions. Such relations in no way imply "favor seeking". A newspaper campaign should be based on the belief that both the newspaper and the school system exist for service to the community; that the individuals in charge of both institutions are good citizens who should meet each other on an equal plane that this service may be the better performed. School superintendents, editors, and reporters should be the best of friends, even though they may disagree. Such friendship will lessen the disagreement.

If the attitude of newspaper men toward this study is an indication the school administrator will find himself met more than half way by editors in any effort to inform his public in the daily press. 


\section{THE GRAN THE GRAN}

S GIE GER ANY MAY

\begin{tabular}{|c|}
\hline 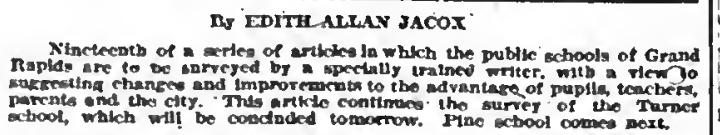 \\
\hline
\end{tabular}

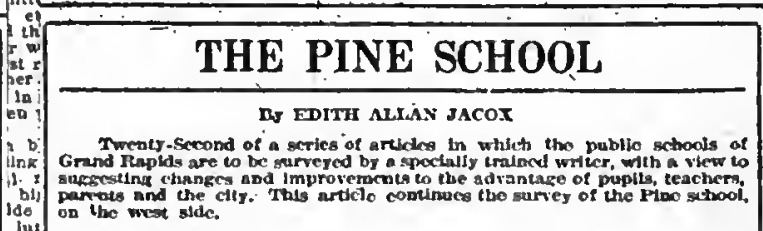

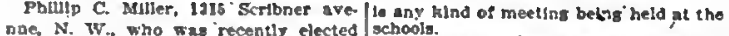
to the ochool board, has lived in the Taxition Without representafloo.

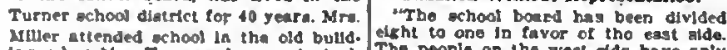

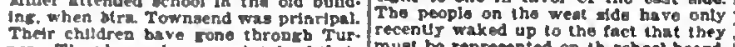

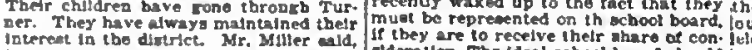
in part:

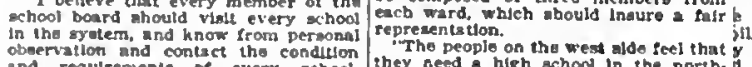

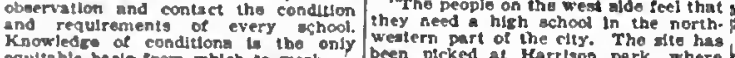

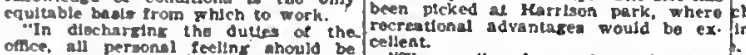

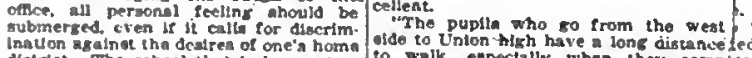

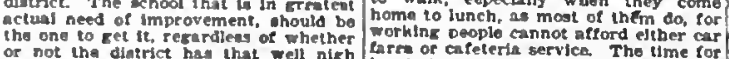

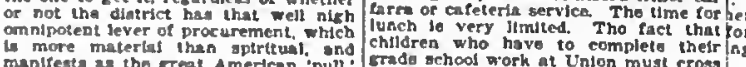

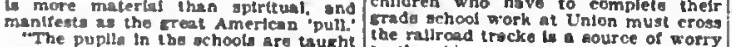

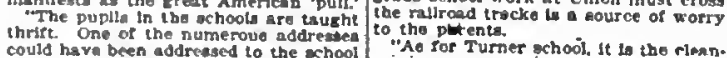

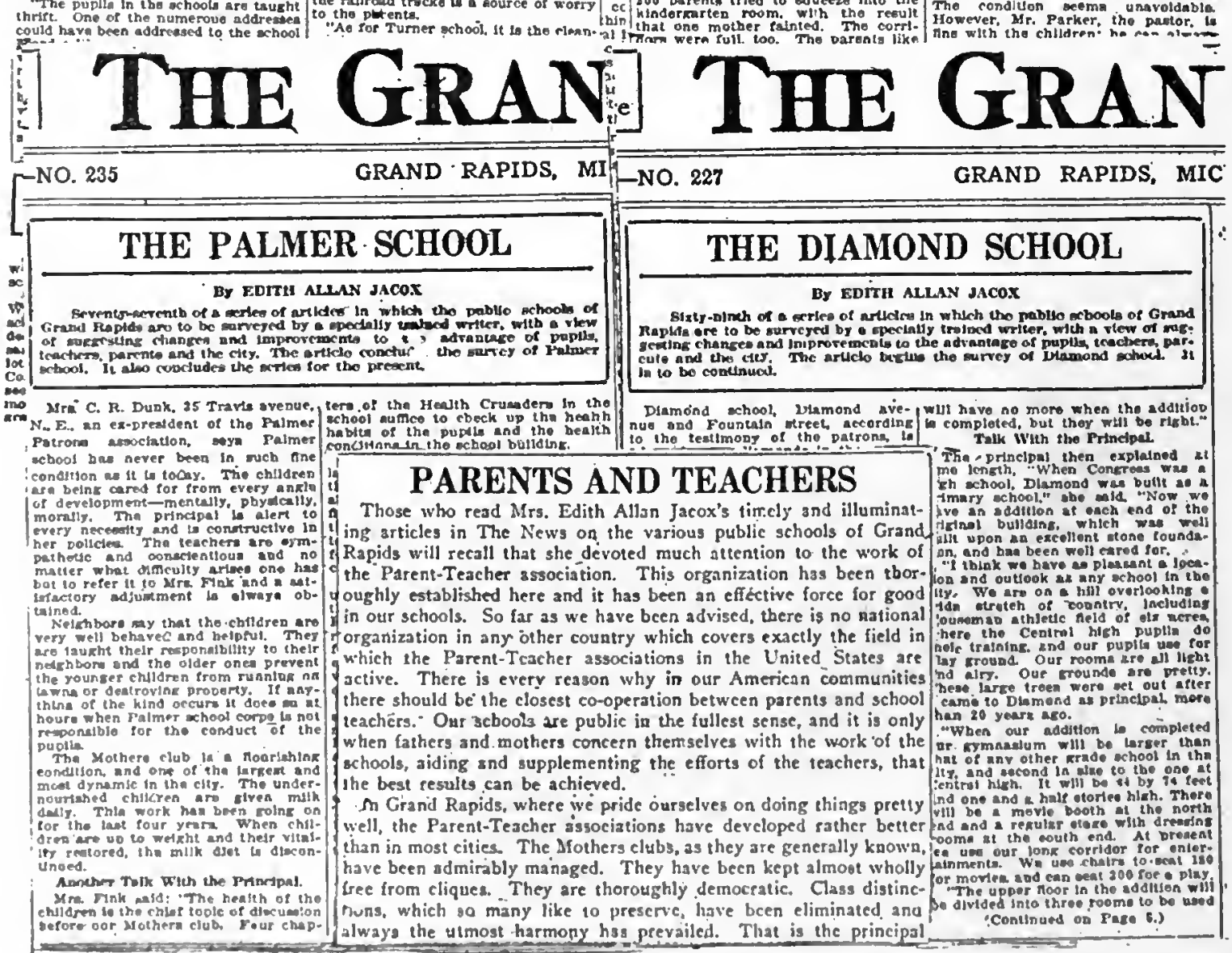

SAMILES OF ARTICLES IN A CONTINUOUS CAMPAIGN

Nearly 100 of these articles were published in consecutive issues of the newspaper. They were aliways on the front page 
2. Professional Relations:

(a) The Distribution of School News.

Most cities have more than one newspaper. In professional relations between the school system and these newspapers, fairness and impartiality should be maintained. This is extremely important. Some understanding should be arrived at, as to the fair distribution of school news which is prepared and given out by the school system. This arrangement will depend upon the local situation. It should be determined by representatives of school system and all newspapers. Some of the methods used by school systems to provide for fair distribution of news were discussed in Chapter IV. They are for convenience listed briefly below.

(I) All newspapers are entitled to news of the public school. Each newspaper has its own body of readers who are citizens of the community and patrons of the public school system. The standing or character of a newspaper should not determine whether school news should be furnished.

(2) Send duplicate copy of all news to each newspaper.

(3) Where all papers issue a Sunday edition save the big stories for this edition.

(4) If desired, alternate news between newspapers.

(5) If desired, separate the school news day into the respective fields which the newspapers cover.

(b) Independent Securing of News by the Newspapers.

A certain amount of school news will be secured and printed independently of the school news organization. The attitude of the school system in this matter should be to assist in every possible way the newspaper which initiates a school news story. Don't suppress or cover up anything. If the proper personal relations have been established, 


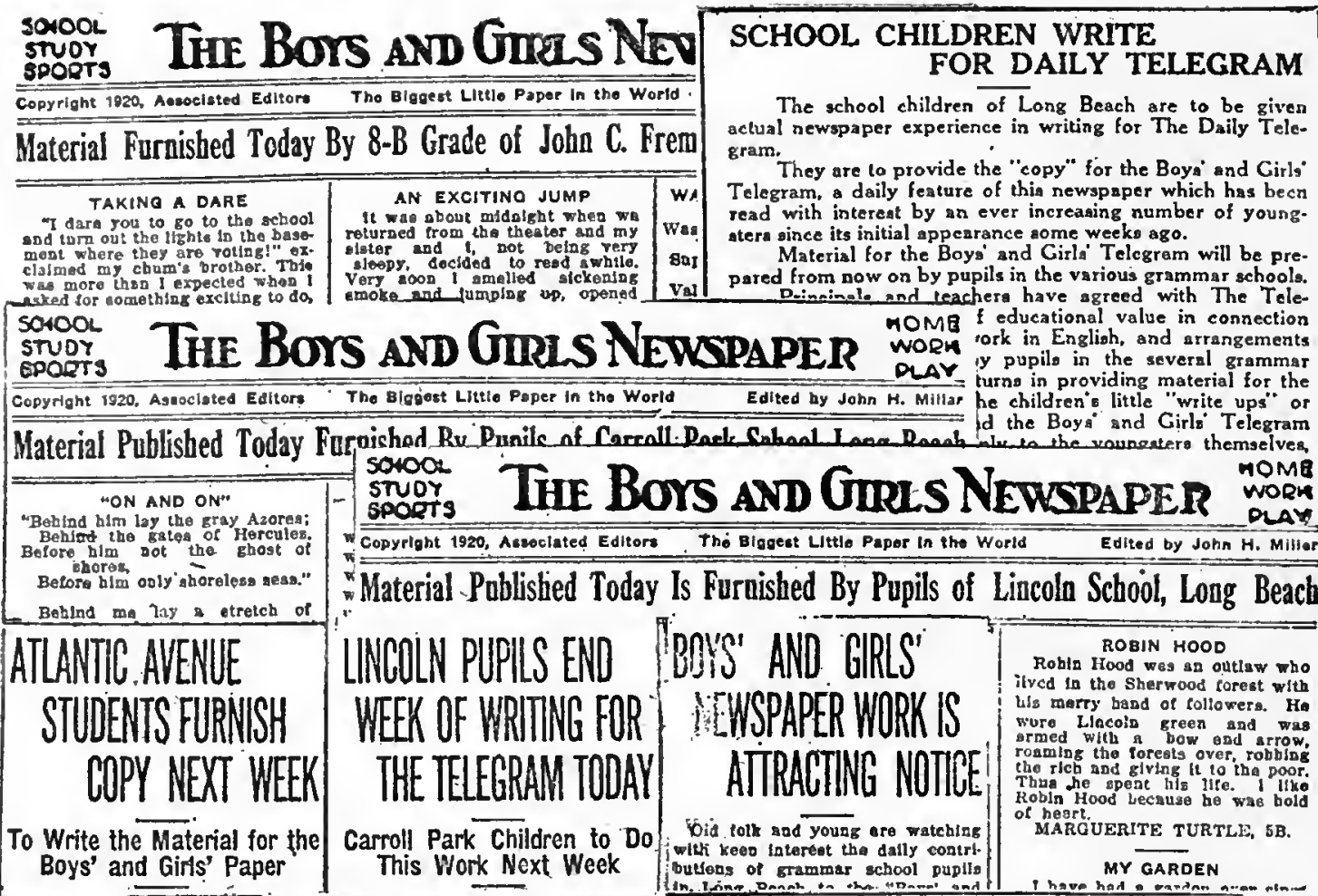

\section{HENRY SABIN School's Tribune}

SNOW BALLING.

\begin{tabular}{|c|c|}
\hline \multicolumn{2}{|c|}{$\begin{array}{l}\text { Twenty-sixth of a Series of Articles in The News Contest to } \\
\text { Develop. Writers Among the Boys and Girls of Grand Rapids. }\end{array}$} \\
\hline \multicolumn{2}{|c|}{ 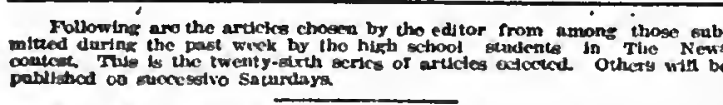 } \\
\hline 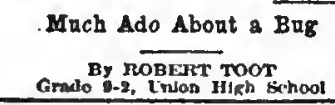 & 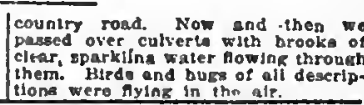 \\
\hline
\end{tabular}

\section{Stories by High School Students}

Twenty-seventh of a Series of Articles In The News Ċontest to Develop Writers Among the Boys and Girls of Grand Rapids.

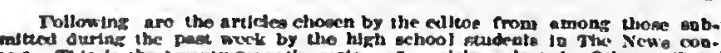

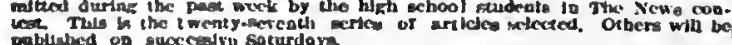

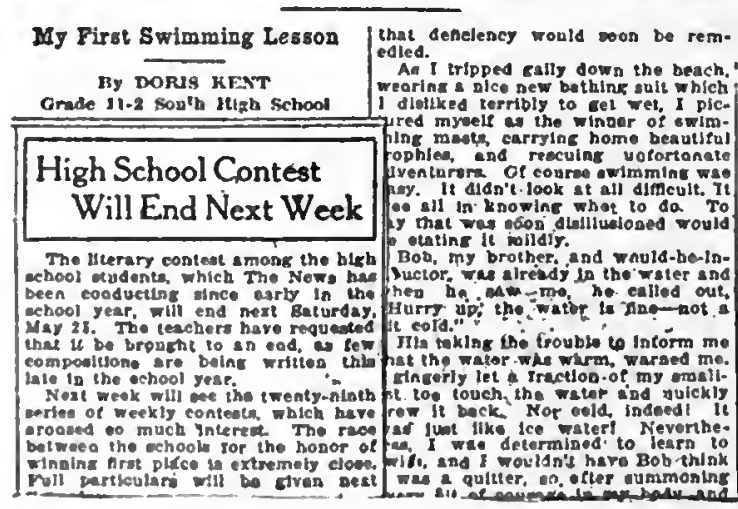

SPORTS.

Le, i1, 6-A.

2 all through the town

whitling donon.

covered with pure white,

through the long night.

$n$ came at last,

t the snow drifted fast. rey all reached the hill, was "fit to kill."

couldn't be beat.

for the feet.

rewly greased boot-

"chute the chute."

their skits at the slides.

the old bob rides.

hes all cold and wet.

$g$ and just what you'll get.

It 80 sore and hoarse.

mer time, of course.

\section{THE SNOWMAN.}

\section{BT HILIN BRIOOs, 2-B.}

Mildred and 1 love to make

noow mas

I awokn one morolog and haw

averytbing covared with. besa-

tiful enow.

I wat o happy at It was oot
vory cold and Just tae day lor

rory cold and just tae cay for

our rloven, costs, and stoking
caps. Then the tun begen. We

rade ands theorball wilh our

groogd astil it was at Isreg an

wo made a torallor bell for

hend. We uzed two atleke tor

Our nowman wa cone and

WINTER.

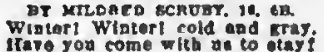

If you ro kod and mild you may

For move to to ran and play

For The love to run and play

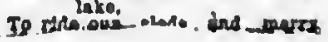

COASTING.

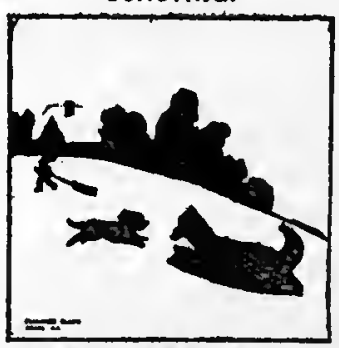

BY MARJORJE CLARK, 4-A.

THE SNOW.

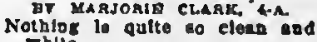
Ae the esow when it talle it And ot, what tun to jump trom Put on your clothes and tat Boour, and milters, eaps, -and wall doo't eare it wa do hero. Iaro that floffy. teathery glaoes. solt as down trom graudpa

THE SNOW FLAKES

seo at ALtce. MUAPHT, A.A.

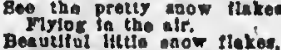

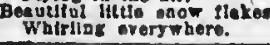

CAGED LIONS

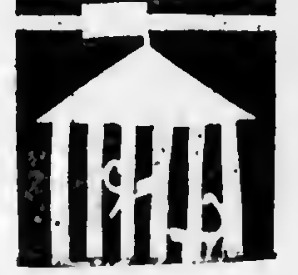

DEPARTMENTS IN A DALLY NEWSPAPER CONTRIBUTED BY SCHOOL CHILDREN 
the newspaper organization and the school news A Program service staff will determine together whether it is for School for the interests of the community and the school News to publish certain school news. This does not imply "censorship" or "control" of news channels. It does imply cooperative good citizenship on the part of school and press. Some school authorities believe that all school news should be secured and prepared independently by newspapers.

\section{(c) Professional Assistance by Newspaper Organization.}

It is the business of the newspaper staff to know how to secure, prepare, and present news to the public. The school news service organization should take advantage of this skill. Advice from editors, instruction by skilled reporters, any assistance which can be secured, will make the school publicity service the more effective. It may be that the newspapers should be represented in the school system's organization.

\section{WHAT SCHOOL NEWS SHALL BE PRESENTED?}

I. Subject Matter.

Distinguish between news and propaganda.

Omit personal exploitation.

Don't forget that it is the unusual that makes news.

Routine is not news.

Play up the "human" element in news.

2. Types of School News.

This matter will require the careful consideration of the school news service organization. It will, of course, have to be determined finally by the decision of the newspaper organization as to the types of school news which it wishes to publish. Below, the different possible types and departments will be briefly discussed. Such of these as seem desirable can be selected to make up the year's publicity program.

(a) News as such:

From a consideration of the opinion of newspaper editors, it is evident that this is the 


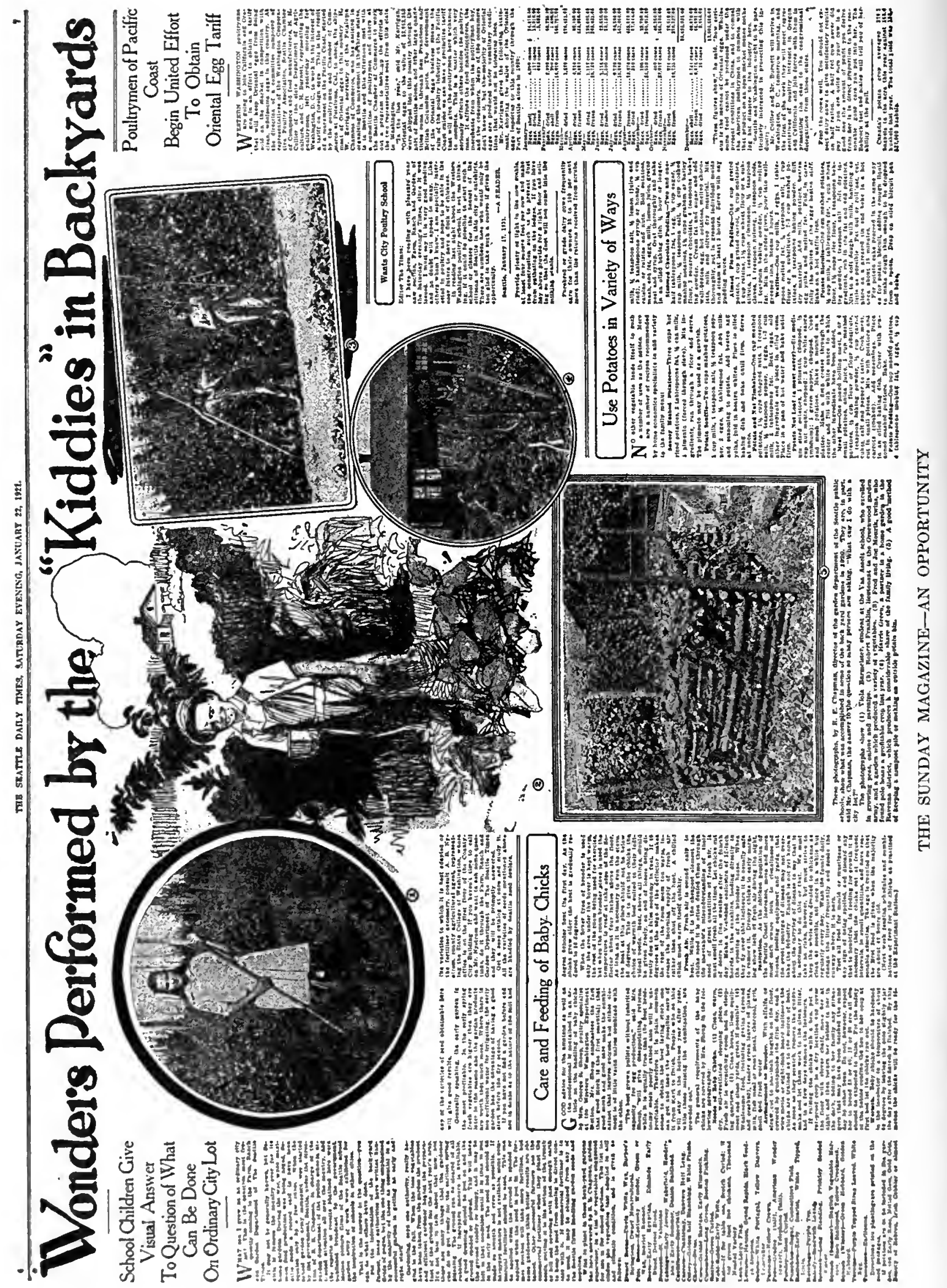


type of school news which the newspaper is A Program most anxious to secure. It must contain for School the elements of news, namely, general inter- News. est, timeliness, the unusual. It must contain the elements of newspaper style, a statement of facts, simplicity, conciseness, with the gist of the story in the first paragraph or 'lead'. To some extent, the happening of events will determine the publication of this type of news, but, when skill in discovering and emphasizing the news "story" is acquired, many a subject which is now treated as propaganda or discussion can much more successfully accomplish its end as "news". School "news as such" will compete with other news. Its position will depend upon the elements in it which determine the position of all news in the paper. This type of school news should more and more receive the emphasis. It meets with the especial approval of editors. It will be read by more general newspaper readers than any other type. It is illustrated in Figure 23, page II.

(b) A School Page.

It may be possible to arrange for a school page in the newspaper. There are two kinds:

(I) A page which is a miniature newspaper of the system dealing with various matters, such as that shown in Figure 24, page I4.

(2) A page in which only one subject is treated at a time as shown in Figure I3, page 100.

The school page will be read mostly by those already interested in the school. It is. a good medium through which to interest and gain the cooperation of patrons; it may serve as a means of creating "esprit de corps" among the teaching staff; it can be used to 


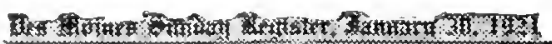
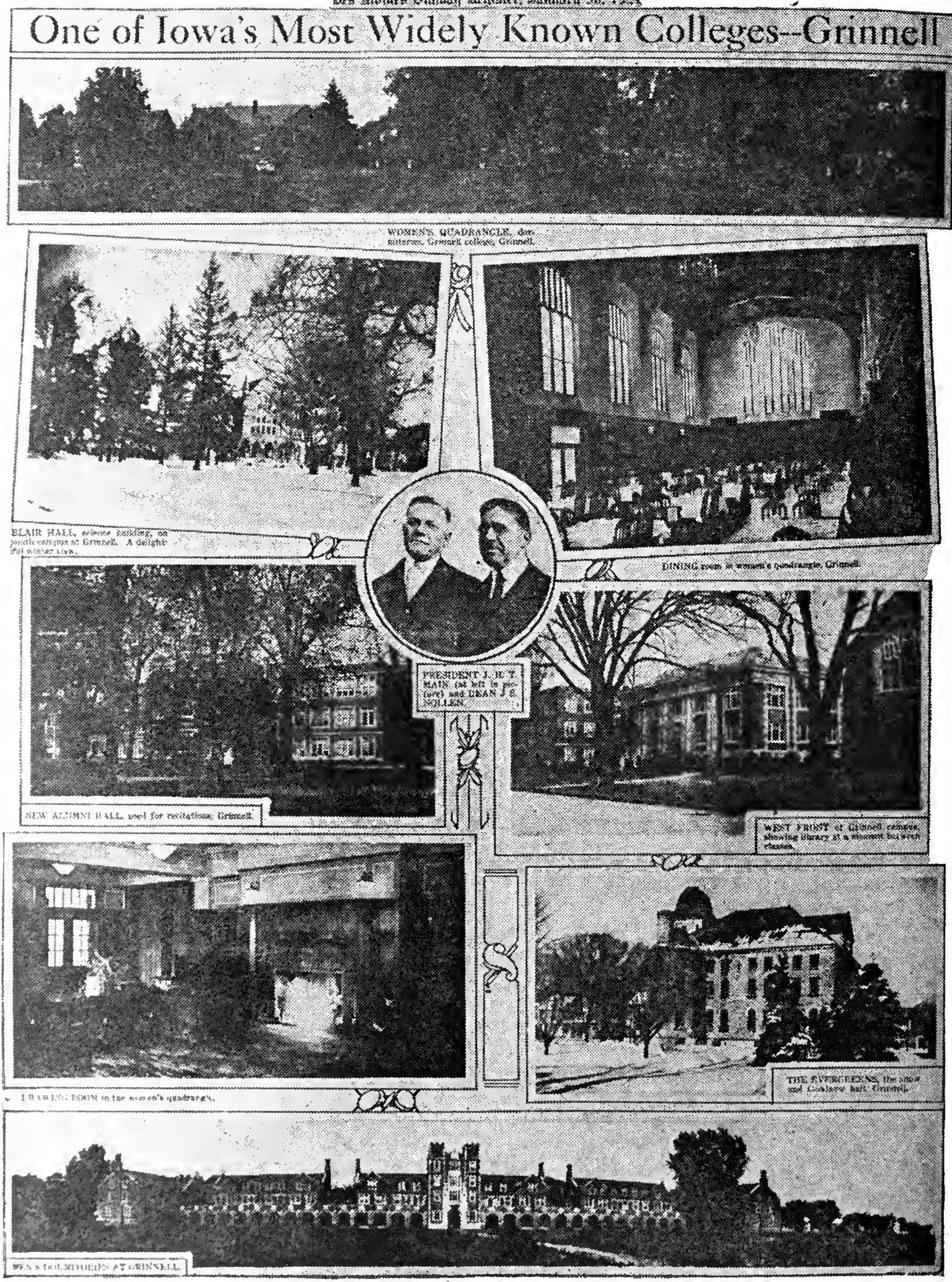

IIICATINAL PLISICITY DE LUXE-THE SUNDAY ROTOGRAVURE SECTION 
create and maintain the interest of school $A$ Program children. Illustrations will increase the for School effectiveness of the school page. They will News. be worth while, even if the school system has to pay for them.

(c) The School Column.

This type is a miniature of the school page. It is used where a whole page is not available. Like the school page, it is of two kinds, both of which are illustrated in Figure 14, page IO2 and Figure 28, page 95.

(d) Special School News Feature Articles.

This type of school news is also in great favor with newspaper editors. They believe it is much more effective than the fixed types such as the school column. The news feature story permits the interesting features of the school system to be brought to the attention of the public. This type differs from "news as such" in that it can be longer; it can go into more detail; it permits more use of illustrations. Several of these feature articles are shown in Figure 27, page 6. Figure I5, page IO4 illustrates the fact that school news does command place on the front page. The articles illustrated were part of a series which appeared approximately Ioo times on the front page of the newspaper. They were evidently prepared by a special correspondent, and cover each public school in the city.

(e) School Notes.

These are most often written by a student reporter. High school notes are most common, but elementary school notes are published in some newspapers. As a usual thing, they deal with student activities, student personals, and the social happenings of the school. In most instances, they are very badly done. In some publicity programs they may find a place, but they should be carefully planned and edited, and be made to add to the whole program. 
Now, My Idea Is This!
Talks With Thinking Buffalonians on Subjects
They Know Best.

BUFFALO'S PART-TIME SCHOOLS. By WILLIAM J. REGAN,

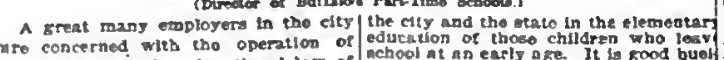
that rection of the edvectional la of compulsory pacs tetme schools.

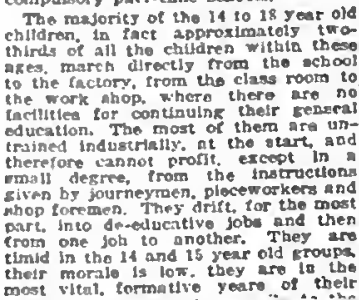

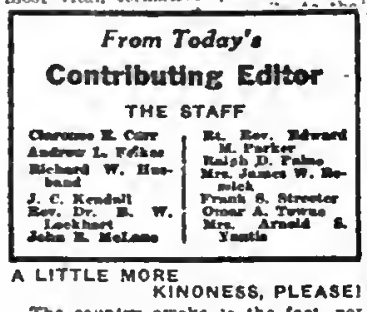
Tho counery awoke to tho tace, not math Long AgO. that achool-teachers bad an irulde was ally of them, but there you wora! They were preasured to reallize that trat

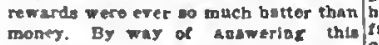
strument they decleed to quit the Job. tesin of thousanda of thom. and sod
out what earnisg is real living was

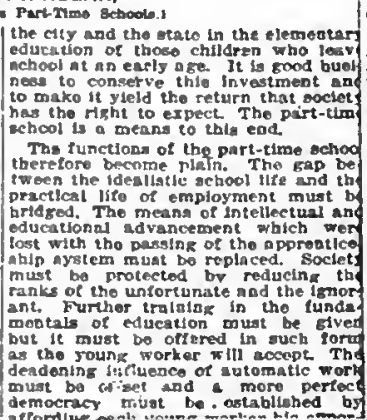

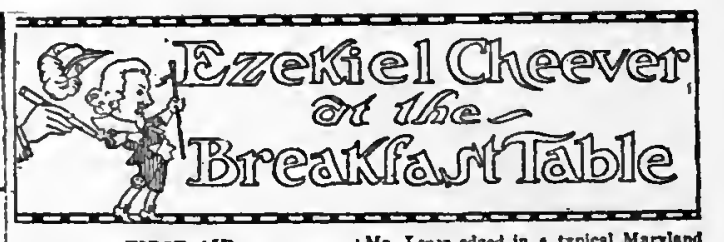

FIRsT Aip.

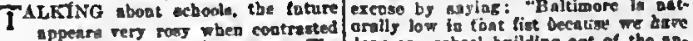
Fith the rottengezs of the preaent. The
buildiags acbool children are now bowsed ire not wallop. oot for Mr. Ieser slose, but for

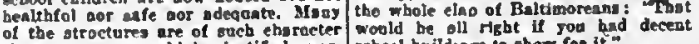

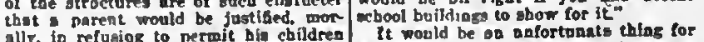
ally, in refuaiog to perwit bis ebildrea It would be ob anfortanats thing for
to eater them, but the eompolsory at- Baltimore, indeed, if, after tho serea

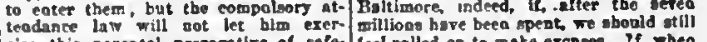

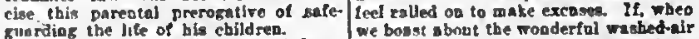

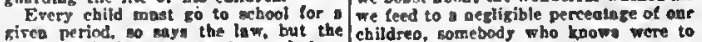
law, which in always wise iod fust. childseo, Bomebody who tyow wore to

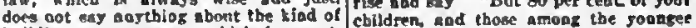

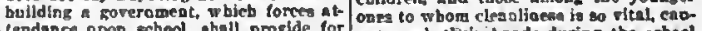

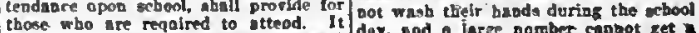

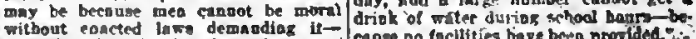

\section{OUR OPINIONS}

\section{Three Simple, Pretty Sty les for High School Girls.}

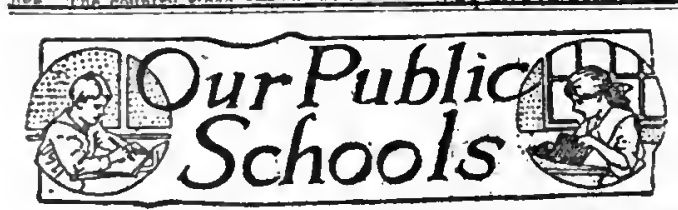

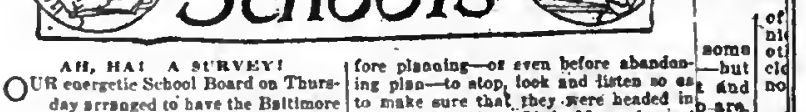
chool syatem aurve jed at inat. It wisely

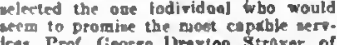
lees. Prot. George Draytoo stroser, of

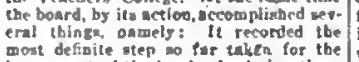

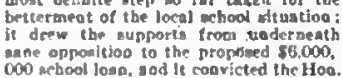

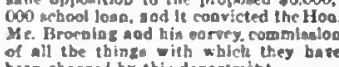

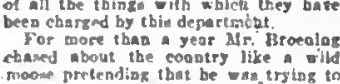
mrranze lor achool worves. hut that be

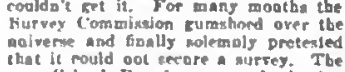
Itat if rould oot secore a sursey. The

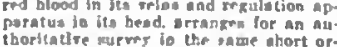
dor that ito whiter offered to do is last
Bueday a numo.

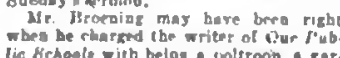

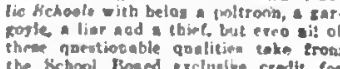
the sphool Broned inclustue credit for

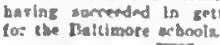

Ir MINED OPFonTeritis:

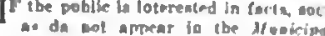

BY PRISCILLA TFAYNE.

At a recent meeting of the West high Parent-j tempted to leave school because they cannot Teachers' association, elghteen girls of tha "keep up."

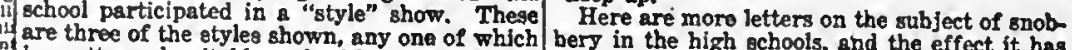
等 Is pretty and suitable and within the reach of upon those who are unable
set. What do you think? skirt are worn by Do you think high school boys and girls of
one-piece dress by today are snobbish? Do you believe the $g$ at the right) and ing of a standard high school costume wear ston (seated). help the situation? lothe their daughtere What DQ rou think?

lal was Delinquent Homes-Delinquent Children.

\section{Dy xhs. J. E. Lestre}

JUDOE HULBURT onty oftendarn comn wovid lead ons

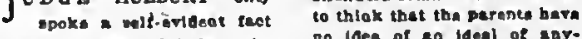
whan tha senerted betors tha go loes of Ra ldenl of any-

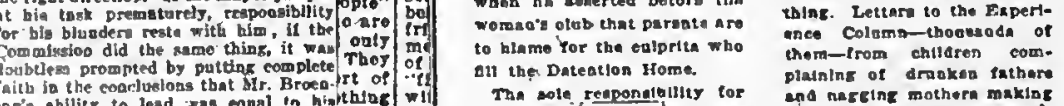

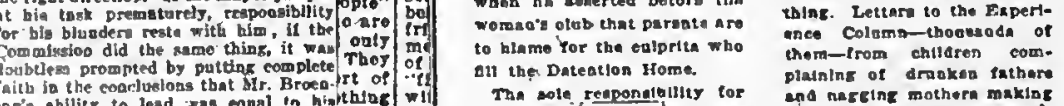

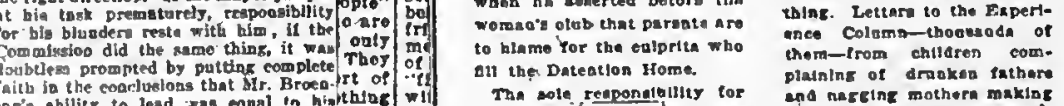

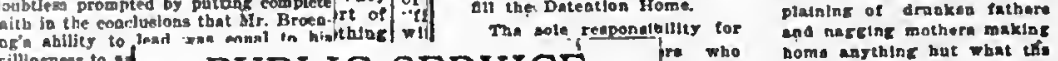

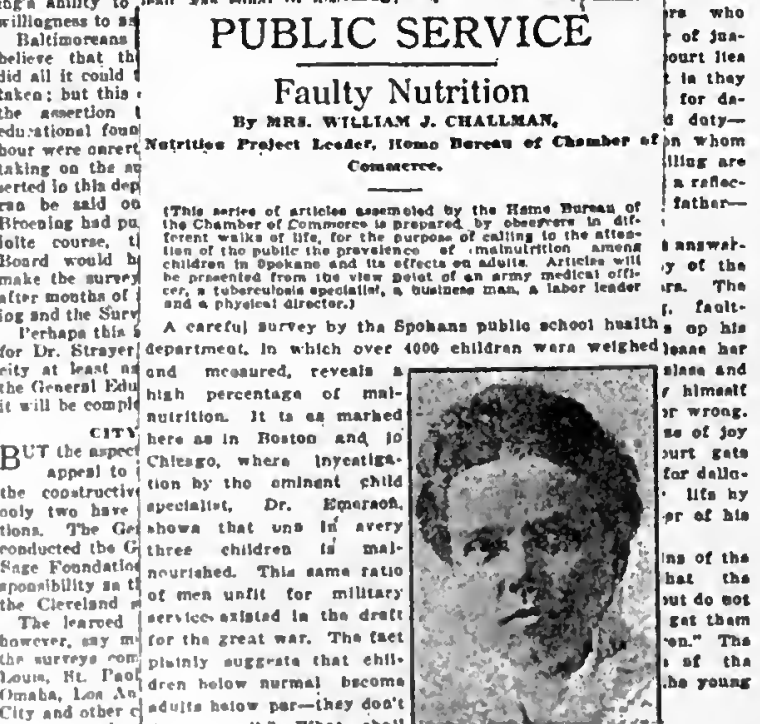
word meass, would polat to lesters elthae cay that the IIttle writare love mother mad try to plesen har, bat le rindin. or olan enay have resebed ths ntege whars thalr satural tove has turand to hatera oodel. ttoe while a anm revoltingly Imposatisin to thoss whow homss ace

nome to be in the moral asd othseal tralaIn the of children bat untace thers th the home tovedaston. thetr work besta marely mapanfotal rusult: that will uor arend the strats of the worts: temptation or the onlidiab foe nartes a of ceace st injuatlea that Alood the whois belse of the nitus injares ond. The atrocolnirs of lave at home to the beat masnconan EEvent the sarnalts court oot soly jeva, tar swe the meaneat perast hes a sateral lovk for bis chlla $\rightarrow$ ut ing

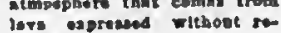
struar 
(f) School Athletic News.

From the reports of editors and superintendents, for School it was learned that a large amount of school athletic news gets into the newspaper. It was stated that this side of school life is over-emphasized by the press. However that may be, athletic news plays a prominent part in school news. It should be as carefully prepared as any other school news and, whenever possible, made to inform the reading public of the relation between school and sport. It cannot be denied that this is one channel through which certain citizens can be interested in the public school system. Probably its proper position is on the general athletic page. In some instances, public school sport news is considered of front page and editorial column importance.

(g) Parent Teacher Association Notes.

A large majority of editors rated this kind of news very highly. It should have an important place in any publicity program. This importance will, of course, depend upon the importance of the Parent Teacher organization in the system. The opinion of school patrons relative to school matters will find a place for its expression in this type of news.

(h) School Board Meeting News.

This is a very common kind of news. It is usually covered by the newspaper itself. It is often the subject of sensationalism. A carefully prepared account of school board meetings, if furnished to the newspapers, might avoid some of this sensational treatment.

(i) Local Teachers' Club News.

Where such organizations exist, news as to their activities should be made a part of the publicity program. The point of view of 
Do Not Forget to Vote on Monday at

the Davenport School Election

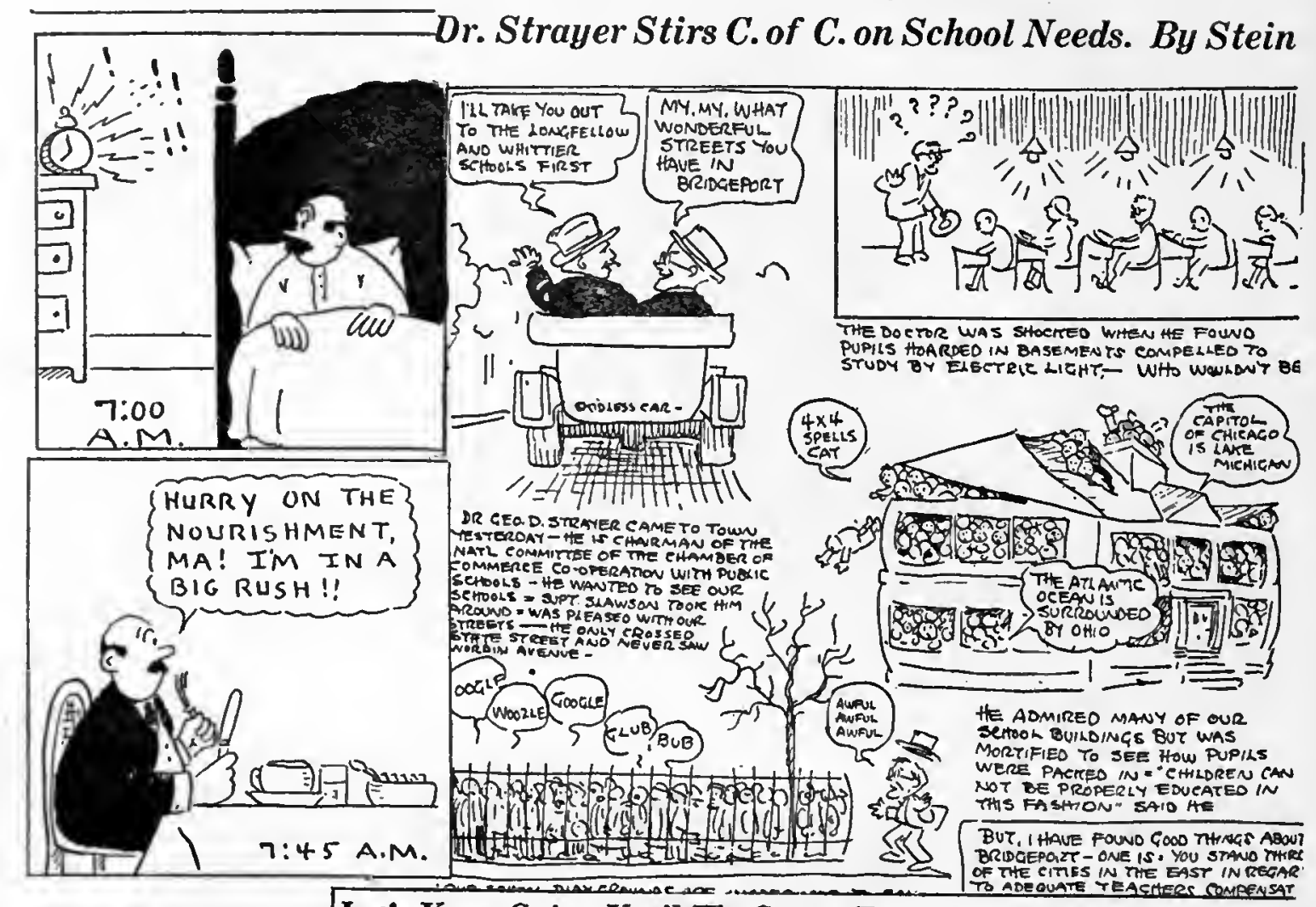

Let's Keep Going. Until We Get to First Street

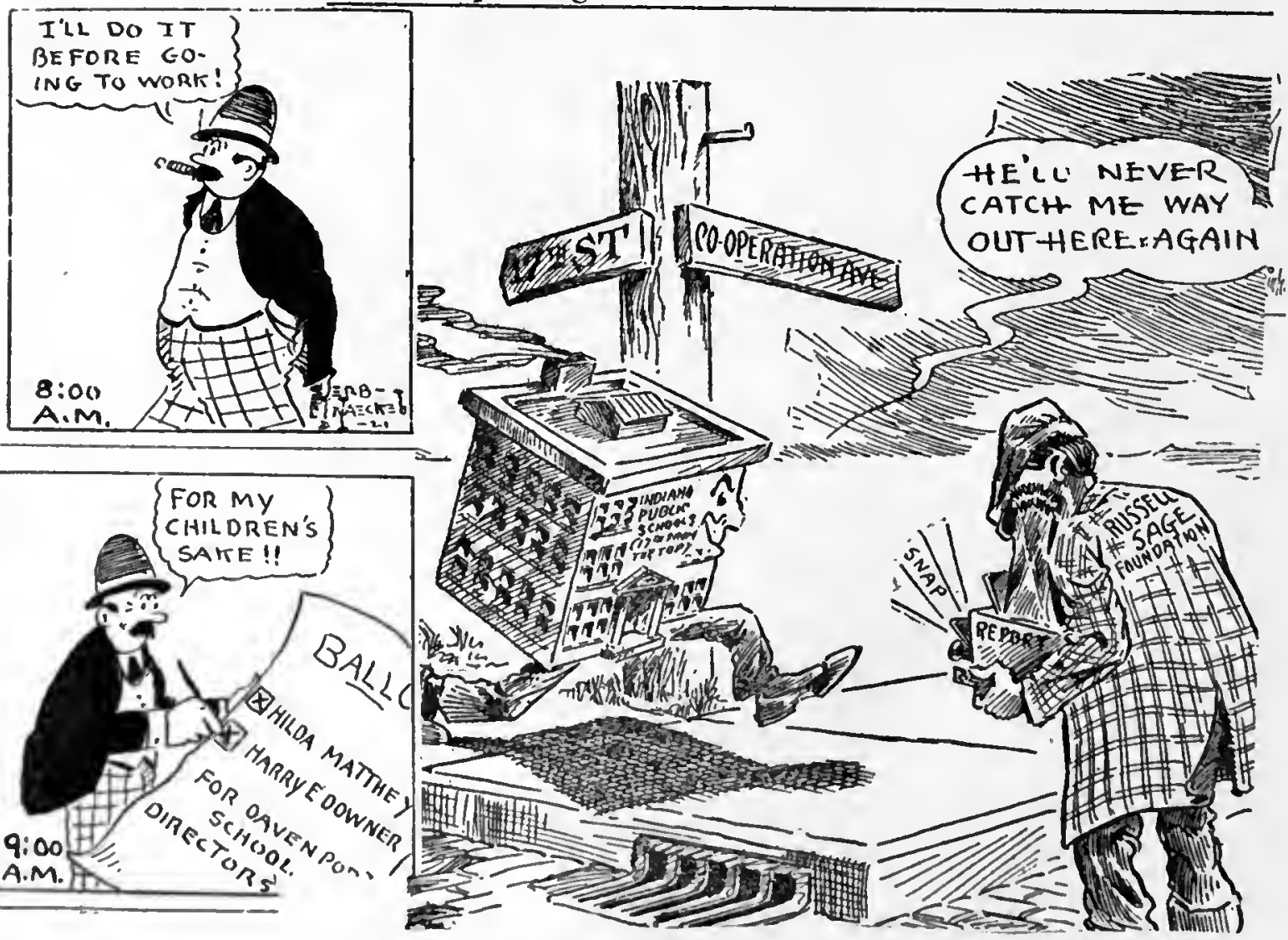

CARTOONS ADAPTED TO SCHOOL PUBLICITY 
the teacher makes good news. An example $A$ Program in Figure 28, page 95 shows how one news- for School paper treats news about teachers. News.

(j) A Page or Department Contributed by School Children.

Figure 16 , page 106 shows how this type is featured in Long Branch, California; Des Moines, Iowa; and Grand Rapids, Michigan. It differs from school notes prepared by students in that the articles, as will be seen, are not of a news character. Its value is probably two fold: first, to interest the children in newspaper writing; and, secondly, to interest the parents in the school. It can be adapted to any grade through the High School. Several editors expressed interest in this type of news.

(k) Editorials.

The use of the editorial for discussing school matters is controlled by the newspaper. Some editors believe that this is the only division of the newspaper which should carry propaganda for, or state opinions relative to, school matters. It is clear that the editorial carries great weight. The proper relations between the school system and the editor will make it possible to secure for education that editorial discussion to which its importance entitles it. Figure 25, page 24 illustrates editorial discussion of school matters.

(l) The Sunday Magazine and Picture Supplement.

School news finds its place in the Sunday edition. It is a good edition for school news. The Sunday magazine is adapted to articles of considerable length. A series of such articles on school matters could be made a very important part in a publicity program. Pictures are a good publicity. The Rotogravure Section of the modern Sunday newspaper offers excellent opportunity for picturing the plant and activities of the 


\section{Enrollment in Bangor Public Schools on Sept. 1, 1920}

Fon semtemaen 11920

一 AGE GROOE TABLE- -

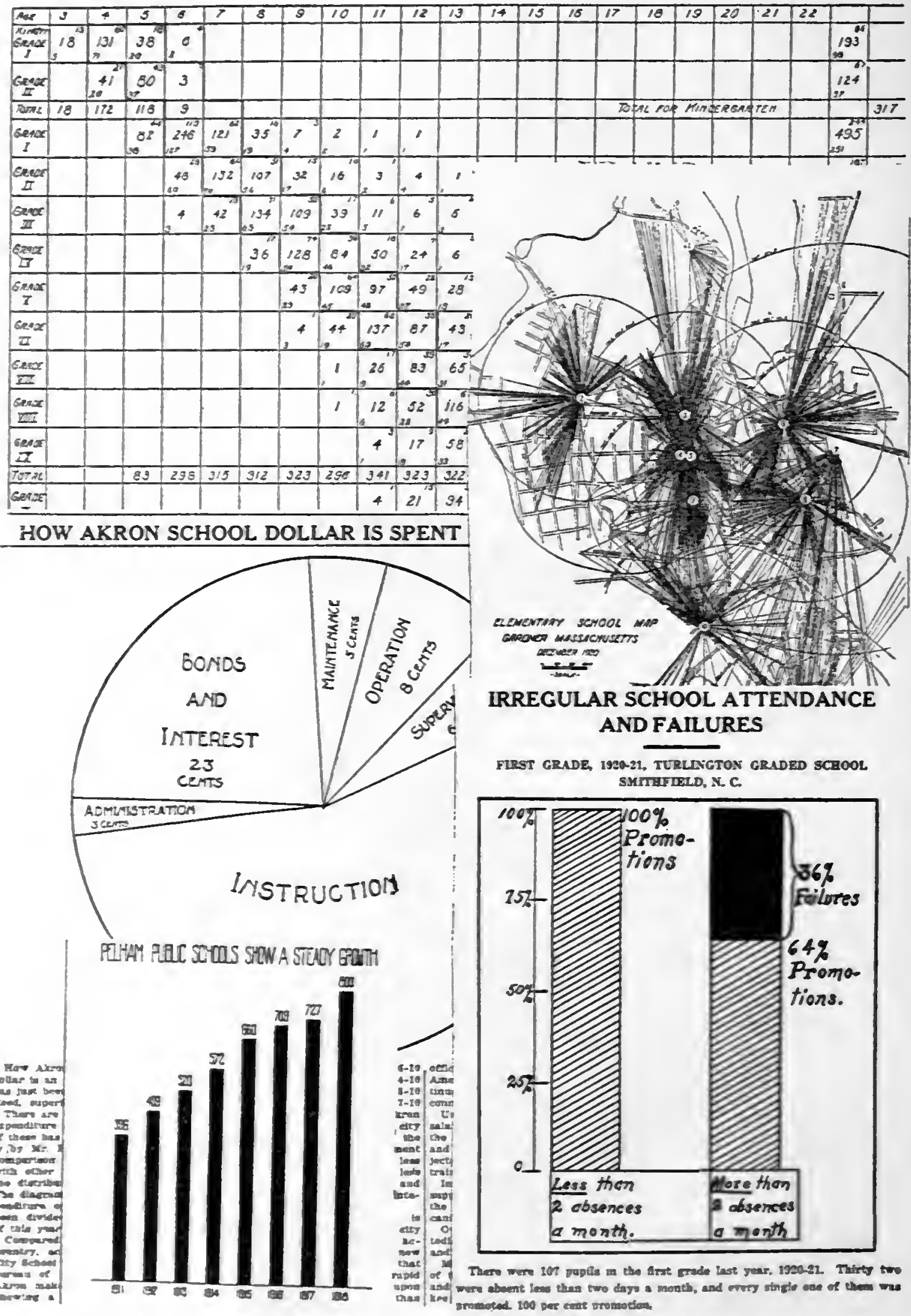

CHLRTS AND GRAPES WHCH HAVE BEEN PUBLISHED IY NEWSPAPERS 
school system; colleges have utilized this A Program kind of publicity to a considerable extent. for School A public school news organization ought to News. be able to convince an editor that the public schools of any city offer splendid subjects for rotogravure pictures in the Sunday edition. Figures 17 and I8, pages 108 and I IO show school news in the Sunday edition.

(m) The "Column".

Figure 19, page II2 shows that the special columns find school news of interest. The special column writer may be made a valuable member of any public school news organization.

(n) Cartoons.

To some, the use of cartoons to carry school news may seem undignified. However that may be, many reforms have been achieved by the use of newspaper cartoons. Figure 20, page 114 shows some examples of the cartoon as adapted to school news purposes. Observation will prove that cartoons are much read. They have the quality of being easily understood. They have a place in some school publicity programs.

(o) Charts and Graphs.

The school man is rapidly coming to use charts and graphs to express school facts. They undoubtedly should be utilized in a newspaper program. Figure 21, page I 6 shows some that have been published in newspapers. Their use, however, should be carefully governed by the results desired. For the general reader, only the simplest charts and graphs are effective. Those which contain the elements of the picture are the most effective.

(p) Display Advertising.

Conditions may make it advisable to use paid display advertising. Oftentimes the expense of such publicity will be borne by civic organizations. Figures 12 and 22, pages 98 and 118 illustrate this form of publicity. 


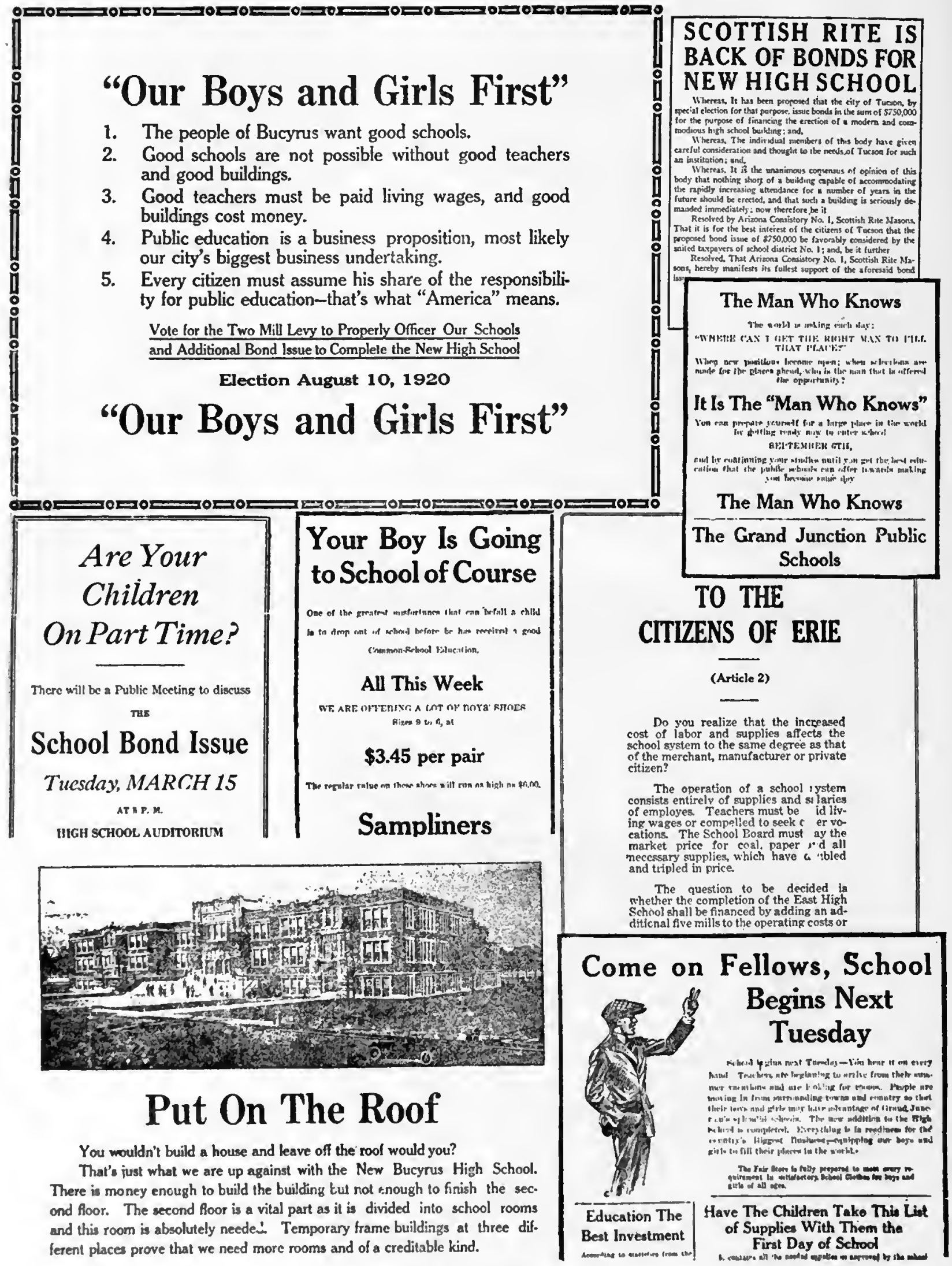


(q) As a Part of the Continuous Campaign, some school A Program systems have been enabled to secure special for School editions of the newspaper for school publicity. News In some cases, the entire edition of the paper has been prepared by the students of a school system or journalism class. In some cases, a special "School Number" has been issued. Figure 26 , page 42 illustrates this cooperation on the part of the newspaper.

\section{CONCLUSION}

A public school publicity or news program should be developed as a part of the whole educational program with the cooperation and advice of newspaper organizations. If it is carefully planned, thoroughly organized, and systematically carried out, it will prove to be of great benefit to the school system. It will be a most powerful agency for securing the interest, cooperation, and support of the public, without which progress is impossible. 


\section{APPENDIX A}

\section{NEWSPAPERS FROM WHICH THE MATERIAL FOR THE NUMBER COUNT AND COLUMN INCH MEASUREMENT WAS SECURED}

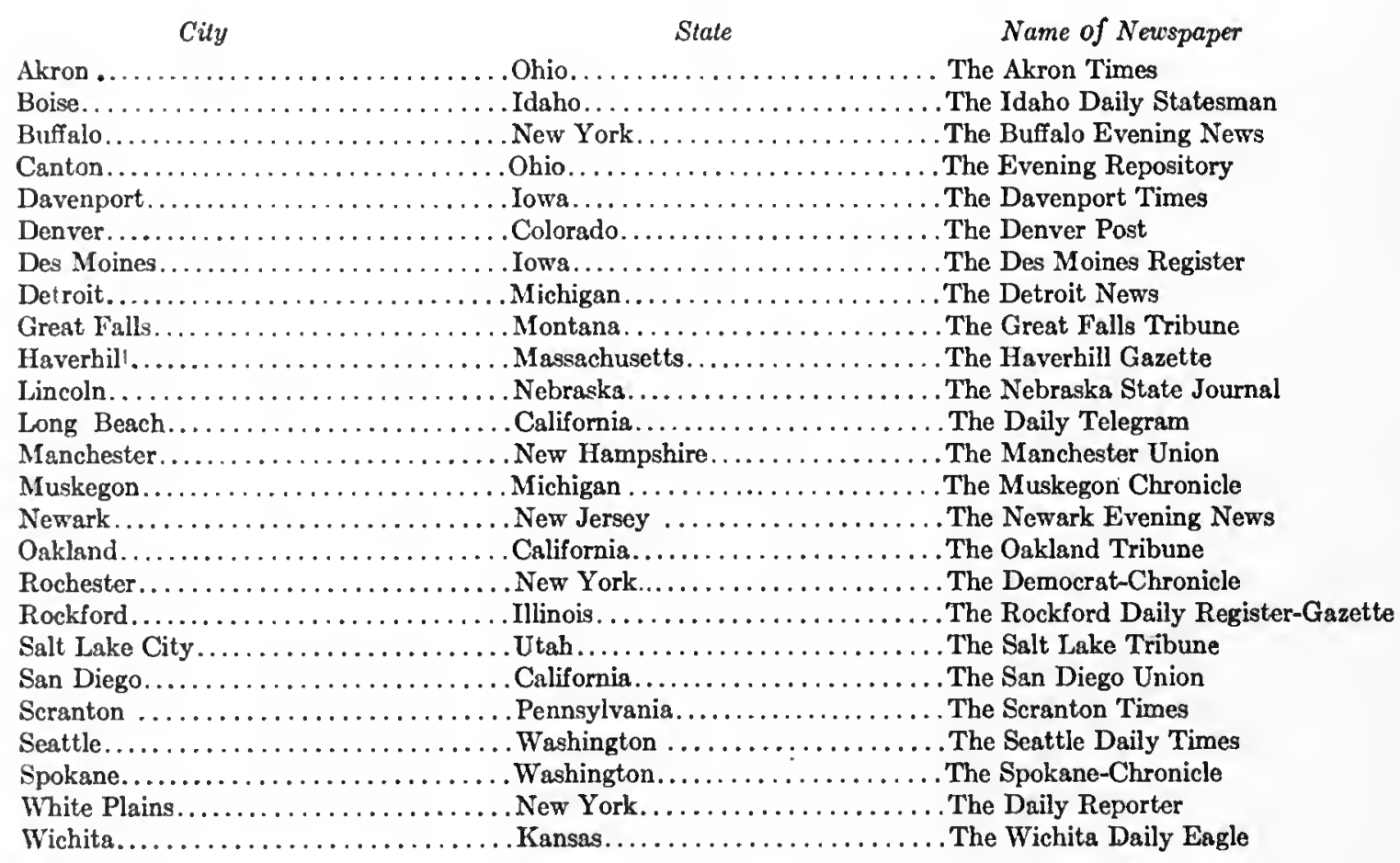




\section{APPENDIX B.}

\section{DAILY NEWSPAPERS COOPERATING IN THIS STUDY}

\section{NEWSPAPERS IN CITIES OF 100,000 AND OVER}

City

1. Akron, Ohio.

2. Boston, Mass................

3. Boston, Mass.

4. Boston, Mass

5. Birmingham, Ala

6. Bridgeport, Conn...

7. Buffalo, N. Y.

8. Chicago, Ill.

9. Cincinnati, Ohio.

10. Dayton, Ohio.

n.........

12. Detroit, Mich

13. Grand Rapids, Mich.

14. Independence, Mo.

15. Kansas City, Mo.

16. Louisville, $\mathrm{Ky}$.

17. Milwaukee, Wis.....

18. Minmeapolis, Minn..

19. Newark, N. J..

20. Philadelphia, Pa..............

21. Portland, Ore.

22. St. Louis, Mo.

23. St. Louis, Mo.

24. Seranton, $\mathrm{Pa}$

25. Seattle, Wash.

\section{Name of Paper}

The Times.

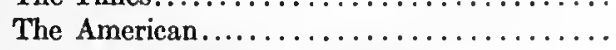

The Christian Science Monitor.

The Transcript.

The News.

The Post.

The News.

The News....

The Post. . .

The News.

The Register.

The News.

The Press.

The Examiner

The Star. .

The Times

The Journal

The Tribun

The News.

The Inquirer .

The Oregonian.

The Globe Democrat

The Post Dispatch.

The Times.

The Times

\section{Edition}

Evening and Sunday

Evening and Sunday

Morning

Evening

Evening and Sunday

Evening and Sunday

Evening

Evening

Evening

Evening and Sunday

Morning and Sundlay

Evening and Sunday

Evening

Evening

Evening and Sunday

Evening

Evening and Sunday

Morming, Evening and Sunday

Evening

Morning and Sunday

Morning and Sunday

Morning and Sunday

Evening and Sunday

Evening

Evening and Sunday

\section{NEWSPAPERS IN CITIES OF 30,000 TO 100,000}

City

1. Allentown, $\mathrm{Pa}$.

2. Canton, Ohio.

3. Charleston, S. C..

4. Chattanooga, Tenn

5. Columbia, S. C.

6. Davenport, Ia.

7. Duluth, Minn

8. Elmira, N. Y.

9. Fort Wayne, Ind.

10. Gary, Ind.

11. Lewiston, Me.

12. Lima, Ohio.

13. Macon, Ga.

14. Manchester, N.H.

15. Mont gomery, Ala

16. Newport, R. I.

17. Ogden, Utah.

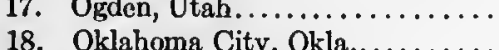

18. Oklahoma City, Okla...........

19. Passaic, N. J................

21. Pittsfield, Mass

\section{Name of Paper}

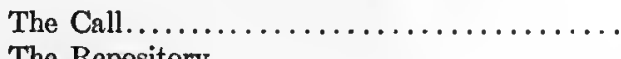

The Repository.

The Post.

The Times.

The State

The Times

The Herald.

The Star Gazette. .

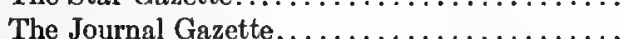

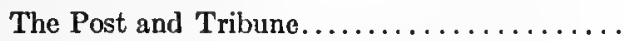

The Journal.

The News and Times Democrat...........

The Telegraph.

The Union.

The Journal.

The News.

The Standard Examine

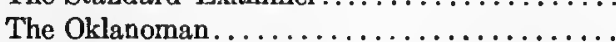

The Herald. .

The News.

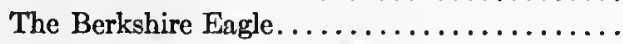

The Express and Advertiser.

\section{Edition}

Morning and Sunday

Evening and Sunday

Evening

Morning and Sunday

Morning and Sunday

Evening

Evening

Evening

Morning and Sunday

Evening

Evening and Sunday

Morning, Evening and Sunday

Morning and Sunday

Morning

Evening and Sunday

Evening

Evening and Sunday

Morning and Sunday

Evening

Evening

Evening

Evening and Sunday 


\section{City}

23. St. Joseph, Mo..

24. Saginaw, Mich.

25. South Bend, Ind.

26. Springfield, Ill.

27. Tacoma Wash..........

28. Taunton, Mass.

29. Terre Haute, Ind

30. Troy, N. Y

31. Utica, N. Y......

32. Wichita, Kan.

\section{Name of Paper}

The News Press.

The News Courier.

The Tribune.

Hois State Journal. ...............

The News Tribune

The Gazette...

The Star....

The Record.

The Press. ...

The Eagle.

\section{Edition}

Evening

Evening and Sunday

Evening

Morning and Sunday

Evening

Evening

Morning and Sunday

Morning and Evening

Morning

Morning and Sunday

\section{NEWSPAPERS IN CITIES OF LESS THAN 30,000}

1. Albion, Mich.

2. Athens, Ohio.

3. Bellingham, Wash.

4. Brownsville, Tex.

5. Burlington, Vt.

6. Casper, Wyo.

7. Cerlar Falls, Ia

8. Cheyenne, Wyo.

9. Elkhart, Ind.

10. Fargo, N. D.

11. Fort Dodge, Ia.

12. Grand Forks, N. D

13. Greeley, Col

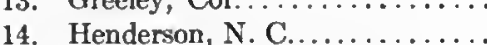

15. Idaho Falls, Idaho............

16. Jackson, Miss....

17. Keene, N. H.

18. Keyser, W. Va.

19. Key West, Fla.

20. Little Falls, Minn.

21. Logan, Utah...

22. Marion, Ohio ........

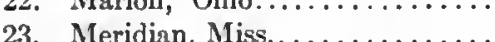

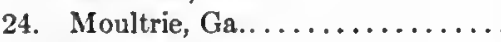

25. Nashua, N. H.

26. New London, Conn

27. Pocatello, Idaho.

28. Pulaski, Va..

29. Raleigh, N. C.

30. Rutland, Vt.

31. Rome, Ga.

33. San Bernardino, Calif.

34. Santa Rosa, Calif.

35. Sioux Falls, S. D.

36. Sterling, Col.

37. Tallahassee, Fla

38. Tusealoosa, Ala.....

39. Wakefield, Mass...

40. Walla Walla, Wash

41. Winchester, Ky.
The Recorder.

The Messenger.

The Herald.

The Herald ........

The Free Press . . . . . . . . . . . . . . . . .

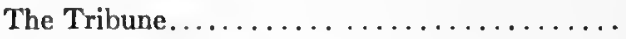

The Record...........................

The Wyoming State Tribune and Leader .....

The Truth....

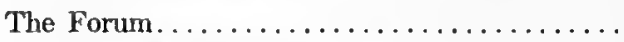

The Messenger and Chronicle.............

The Herald.....................

The Tribune and Republican..............

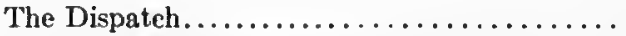

The Times Register.................

The News....

The Sentinel...

The Mineral News.

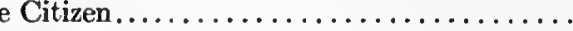

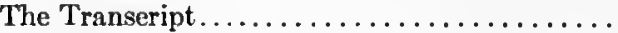

The Journal-.

The Star.

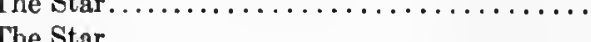

The Observer.

The Telegraph.

The Day...

The Tribune.

Times and News Review......

The Herald .

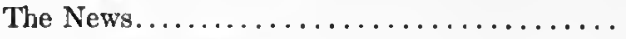

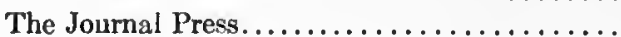

The Sun...

The Press Demoerat.

The Argus Leader.

The Advoeate.

The Democrat.

The News and Times Gazette.............

The Item

The Bulletin.

The Sun.
Evening

Evening

Evening

Evening and Sunday

Morming

Evening

Evening

Morning, Evening and Sunday Evening

Evening

Evening

Morning, Evening and Sunday

Morning and Evening

Evening

Morning and Sunday

Evening and Sunday

Evening

Evening

Evening

Evening

Evening

Evening

Evening and Sunday

Evening

Evening

Evening

Evening

Evening

Morning and Sunday

Morning

Evening and Sunday

Evening

Morning and Sunday

Morning and Sunday

Evening

Evening

Evening

Evening and Sunday

Evening

Evening and Sunday

Morning and Evening 
APPENDIX C.

\section{LIST OF CITIES IN WHICH THE PUBLIC SCHOOL SYSTEM COOPERATED.}

City State

Aberdeen..................... South Dakota

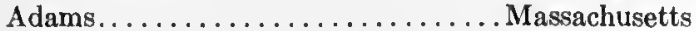

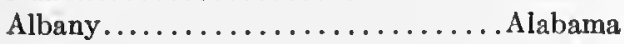

Albuquerque.................. New Mexico

Alexandria.................... Indiana

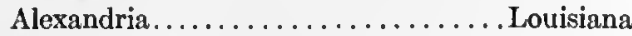

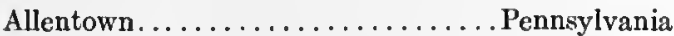

Altoona..................... Pennsylvania

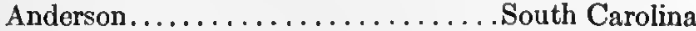

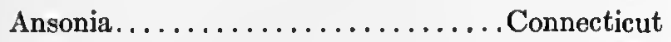

Asbury Park................. New Jersey

Astoria........................ Oregon

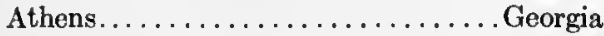

Atlanta....................... Georgia

Bakersfield.................. California

Bangor....................... Maine

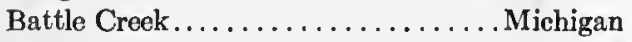

Bayonne...................... New Jersey

Bellows Falls................. Vermont

Bennington.................. Vermont

Berkeley...................... California

Binghamton.................. New York

Birmingham..................Alabama

Bloomfield..................... Jew Jersey

Bloomington................... Indiana

Bowling Green................. Kentucky

Bowling Green.................. Ohio

Bozeman............................

Brattleboro................... Vermont

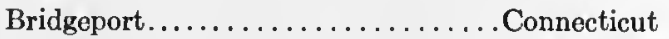

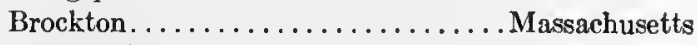

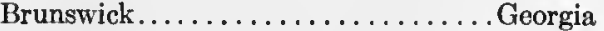

Buffalo..................... New York

Burlington.................. Iowá

Burlington.................. Vermont

Cairo......................... Illinois

Canton...................... Illinois

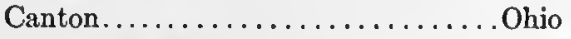

Cape Girardeau................... Missouri

Carlisle..................... Pennsylvania

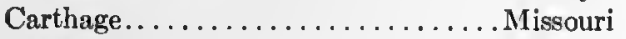

Cedar Rapids................ Iowa

Central Village................. Connecticut

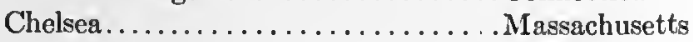

Chester......................Pennsylvania

Cheyenne...................Wyoming

Chickasha................... Oklahoma

Chicopee......................Massachusetts

Cicero...................... Illinois

Cleveland.................... Ohio

Cleveland................... Tennessee
City

State

Clifton Forge................. Virginia

Coatesville.................... Pennsylvania

Coeur d' Alene.................. Idlaho

Colorado Springs............... Colorado

Columbus..................... Nebraska

Columbus..................... Georgia

Concord................... New Hampshire

Council Bluffs................ Iowa

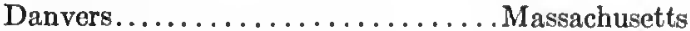

Davenport................... Iowa

Denison..................... Texas

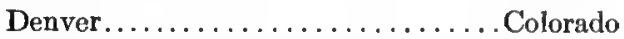

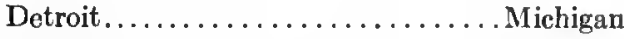

Dubuque.................... Iowa

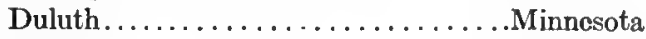

Durham..................... North Carolina

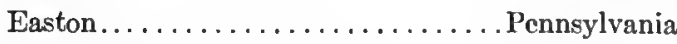

East St. Louis.................. Illinois

Eau Claire................... Wisconsin

Elizabeth..................... New Jersey

Elkins......................West Virginia

El Paso...................... Texas

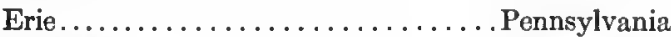

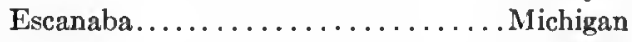

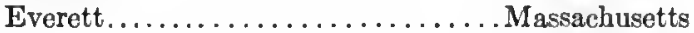

Everett.................... Washington

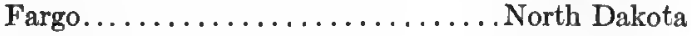

Fort Smith..................... Arkansas

Fredericksburg................ Virginia

Fresno....................... California

Gadsden.....................Alabama

Galesburg.................... Illinois

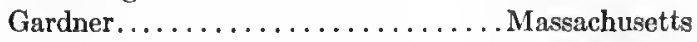

Gary...................... Indiana

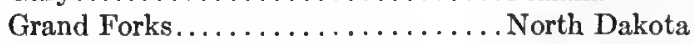

Grand Junction.................. Colorado

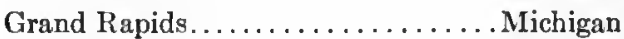

Great Falls.............................

Greeley ....................... Colorado

Green Bay...................Wisconsin

Greencastle...................Indiana

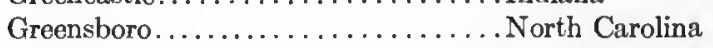

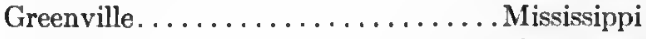

Hackensack................... New Jersey

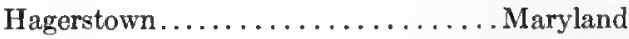

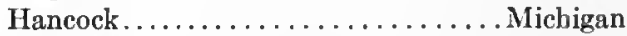

Hannibal..................... Missouri

Harrisburg................ . . . Pennsylvania

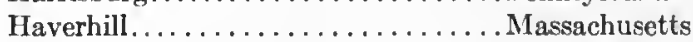

Helena........................ Arkansas

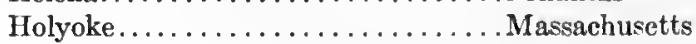


Culy

State

Huron.................... South Dakota.

Independence................. Kansas

Indianapolis................. Indiana

Iowa City..................... Iowa

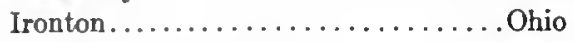

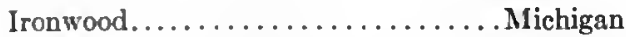

Jackson. ................... Michigan

Jacksonville................. Illinois

Jamestown...................... New York

Jeanette..................... Pennsylvania

Jersey City..................... New Jersey

Joliet....................... Illinois

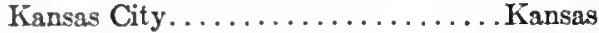

Kenosha..................Wisconsin

Fieokuk. .................. Iowa

Kinston...................... Torth Carolina

İokomo..................... Indiana

Ia Crosse...................Wisconsin

Iancaster...........................

Lancaster....................... Pennsylvania

Lansing. . . . . . . . . . . . . . Michigan

Latrobe...................... Pennsylvania

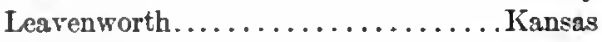

I ebanon..................... New Hampshire

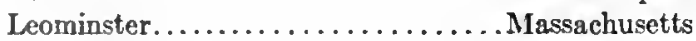

Lewiston.................. Idaho

Lewiston. . . . . . . . . . . . . . . Maine

Lexington ................... Missouri

Little Falls...................... Minnesota

Los Angeles.................. California

Lynn......................Massachusetts

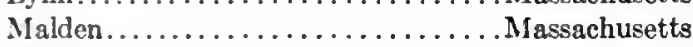

Mamaroneck.................. New York

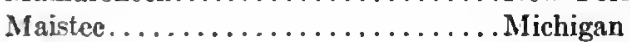

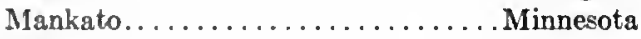

Martins Ferry................... Ohio

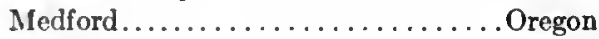

Mexico........................ Missouri

Miami...................... Florida

Middletown.................. Connecticut

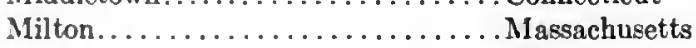

Milwaukce..................Wisconsin

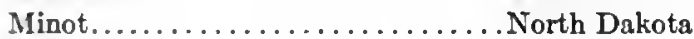

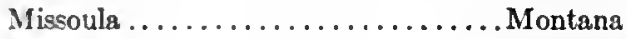

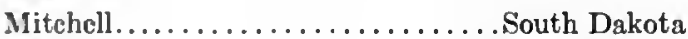

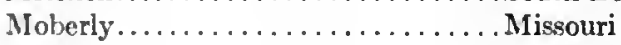

Moline.....................llinois

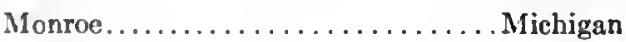

Montelair......................... Jersey

Montgomery.....................Alabama

Montpelicr................... Vermont

Mount Vernon .................. Illinois

Mount Vernon................. Now York

Muskogee ...................... Oklahoma

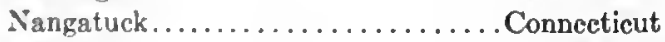

Nashua..................... Ncw Iampshire
Cily

State

Nevada.......................Missouri

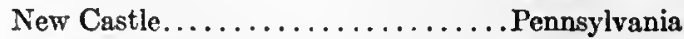

New Orleans................. Louisiana

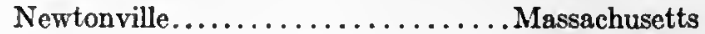

Norfolk................... Virginia

Northampton.................Massachusetts

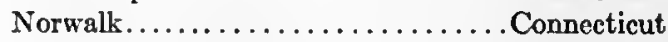

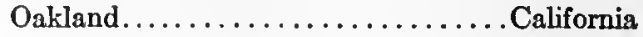

Oak Park.................... Illinois

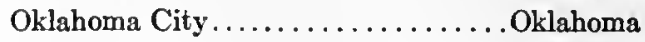

Olympia....................Washington

Omaha...................... Nebraska

Oshkosh ...................Wisconsin

Ottwumwa.................. Iowa

Owensboro..................... Kentucky

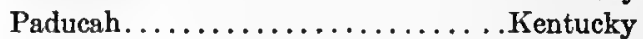

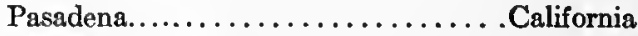

Paterson...................... New Jersey

Philadelphia................. Pennsylvania

Phoenix........................ Arizona

Pine Bluff. .................... Arkansas

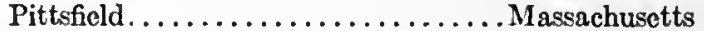

Pocatello................... Idaho

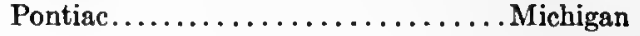

Portsmouth................... New Hampshire

Portsmouth................. Virginia

Prescott......................Arizona

Pueblo...................... Colorado

Quincy.......................Illinois

Raleigh....................... North Carolina

Reading.................... Pennsylvania

Redlands.................. California

Revere......................Massacbusetts

Richmond.................. Virginia

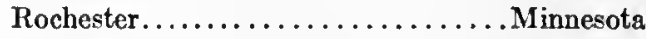

Rochester..................... New York

Rock Island................. Illinois

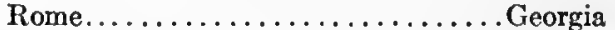

St. Johnsbury ................ Vermont

St. Joseph................... Missouri

Salt Lake City. . . . . . . . . . . . . . . . Utah

San Diego.............................

San Rafael................... California

Santa Barbara................. California

Santa Cruz.............................

Santa Fe.................... New Mexico

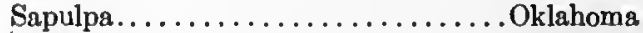

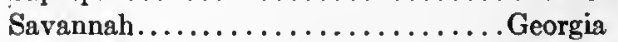

Schenectady.................. New York

Scranton..................... Pennsylvania

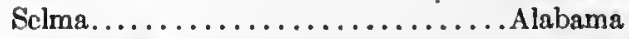

Sharpsburg. ................... Pennsylvania

Shcboygan.................Wisconsin

Shreveport...................Louisiana

Sioux City.................. Iowa

Solvay..................... New York 


$$
\text { City }
$$

Somerville. .

Spokane.

Springfield.

State

Springfield

Stamford.

Streator.

Syracuse.

Taunton.

Terre Haute.

Texarkana. ....

Topeka.

Trenton

Union

Utica......

Vicksburg

Waco.

Walla Walla.

Wallingford

Washington

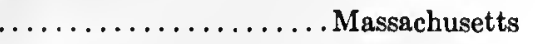

Washington

. Missouri

Ohio

Connecticut

Illinois

Wisconsin

New York

Massachusetts

Indiana

Texas

Kansas

New Jersey

New Jersey

New York

Mississippi

Texas

Washington

Connecticut

District of Columbia

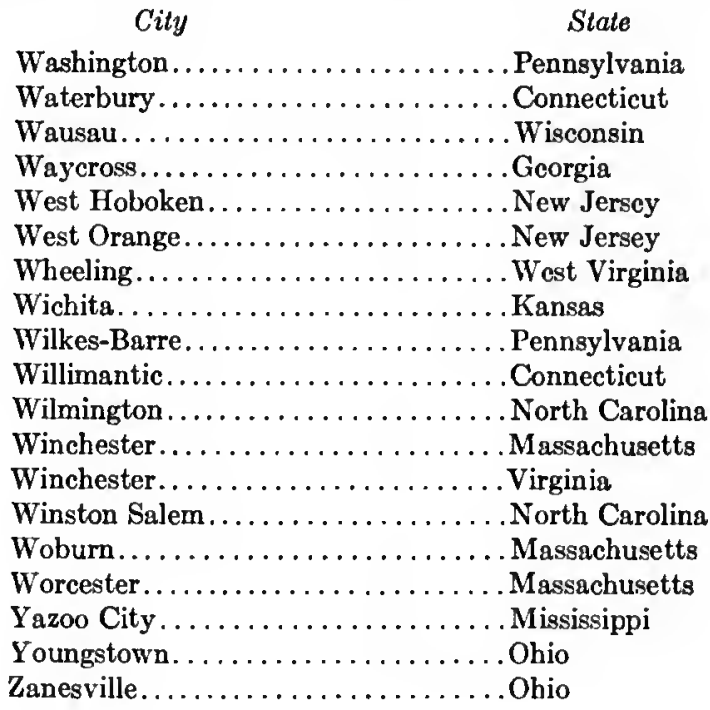

Washington.................. Pennsylvania

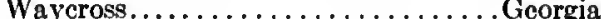

Wheeling.....................West Virginis

Wichita . . . . . . .

Wilmington

Winston Salem.................. North Carolina

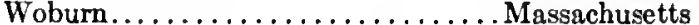

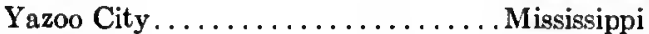

Zanesville..................... Ohio 


\section{VITA}

The author of this dissertation, Rollo George Reynolds, was born at Cambridge, Vermont, on March 31, 1886. He received his early education in the public schools of Vermont and the public high school of Brookline, Massachusetts, from which he graduated in 1906 . He attended Dartmouth College, Hanover, New Hampshire, from which he received the degree of Bachelor of Arts in I9IO. During the year I9IO-I I, he was instructor in history at Juniata College, Huntingdon, Pa. From I9II to 1915 he served as principal of elementary and high schools in Cambridge, Stowe, and Morrisville, Vermont. From I9I5 to 1917 he served as executive secretary to the State Board of Education of Vermont. From I9I7 to I9I9, he was Director of the Theodore N. Vail Agricultural School and farms, Lyndonville, Vermont. During the years, I9I7 and I9I8, he was appointed as State Director for Vermont of the United States Boys Working Reserve and State Chairman of the Boys and Girls Division of the United War Work Drive. In 1919 he served for six months as lecturer with the United States Army Educational Corps in France and Germany.

He was a student at Columbia University during the year 19191920 from which institution he received the degree of Master of Arts. In 1920 he assisted in the educational survey of the public school system of Greensboro, North Carolina. In 1920 he was appointed Director of the Vermont State Summer School at Rutland. He was Associate in Educational Administration at Teachers College, Columbia University, during the year 1920-1921. During the year 1920-192I he assisted in the educational survey of the public school system of Baltimore, Maryland. 


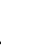




\section{F)}

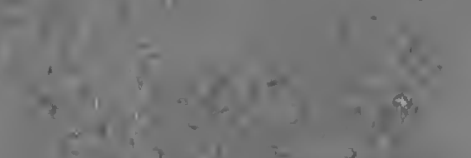

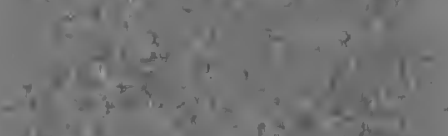

$73 \times 2=$

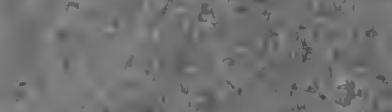

bit. 25

setring

3)

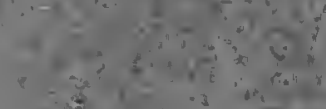

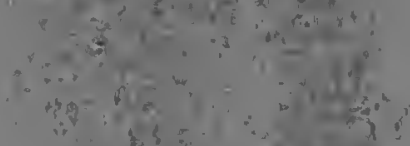

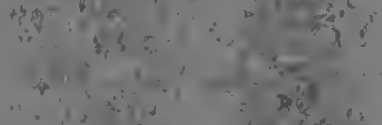

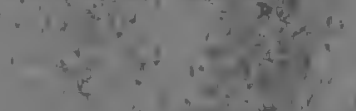

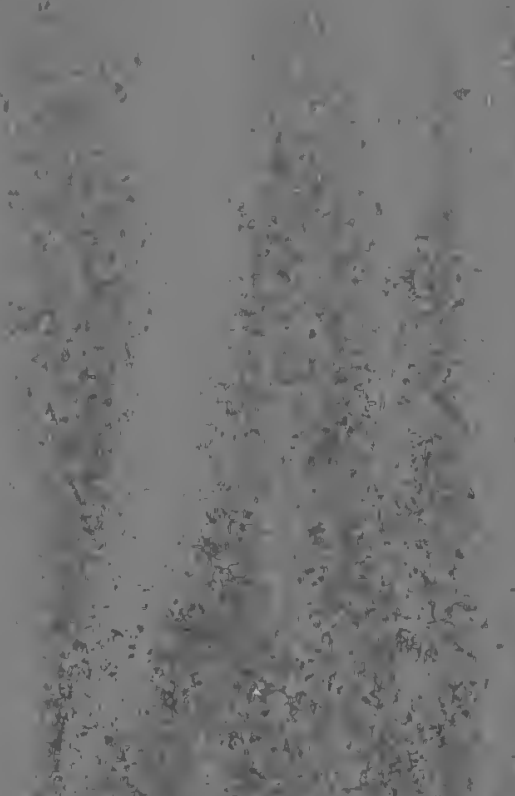

8.

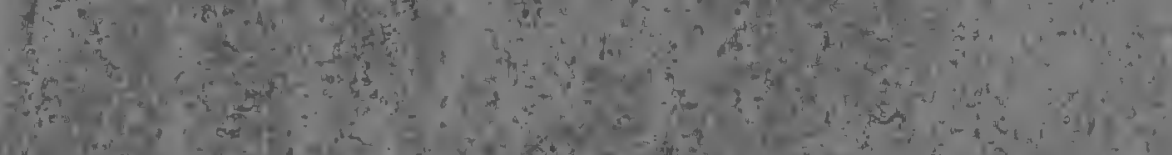

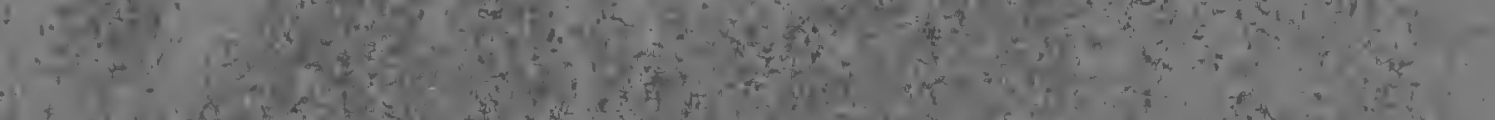

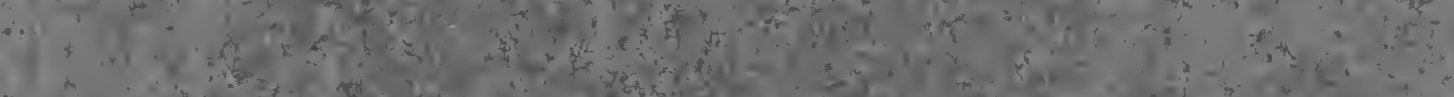

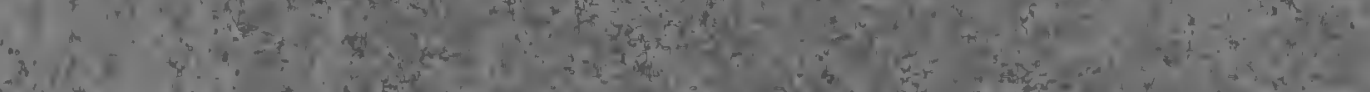

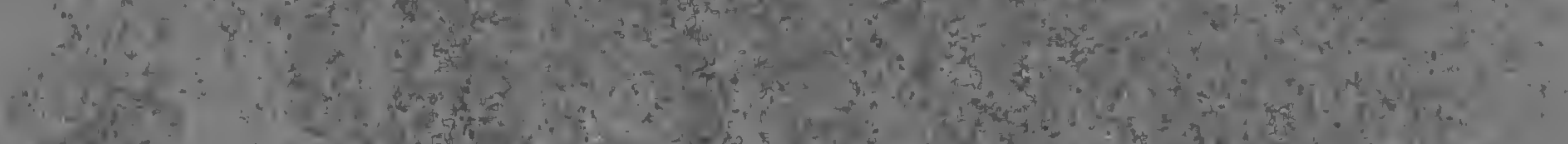

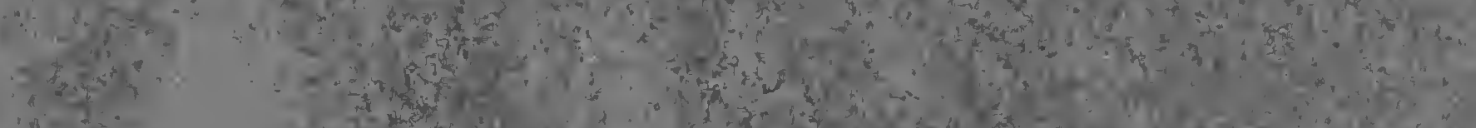
and

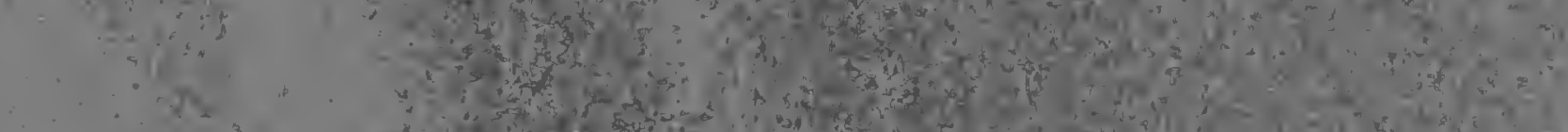
and $\therefore \quad$ (mit: $+4$

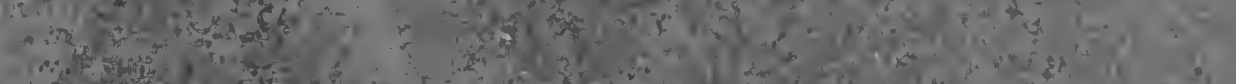

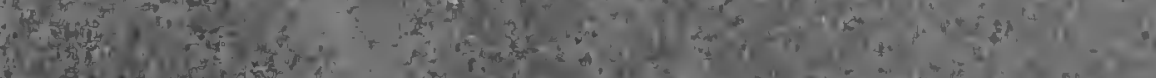

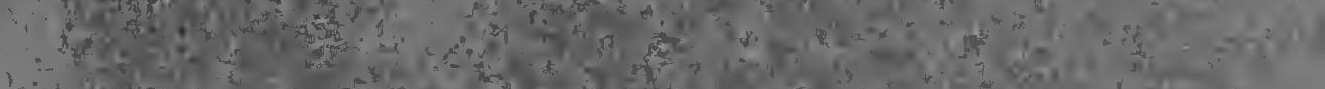
$10 \mathrm{cos}$ a

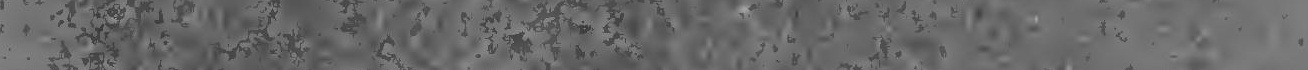
at and

a

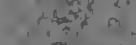

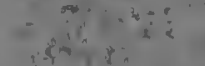

it? (4)

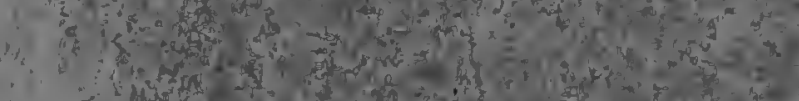

$+4 i^{4}$

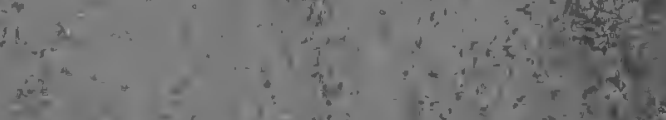

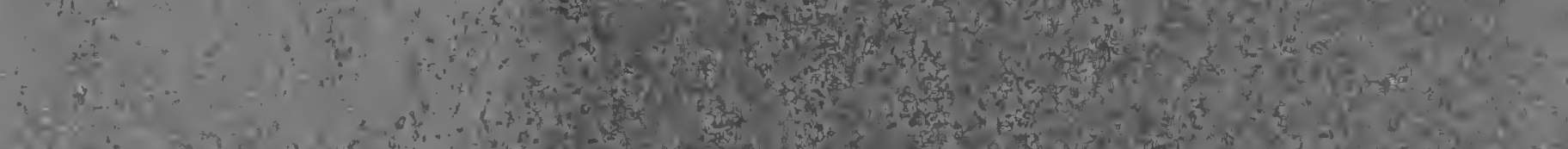

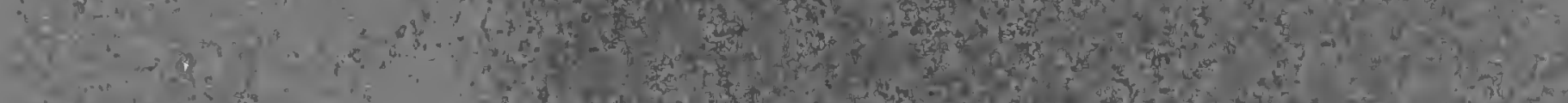

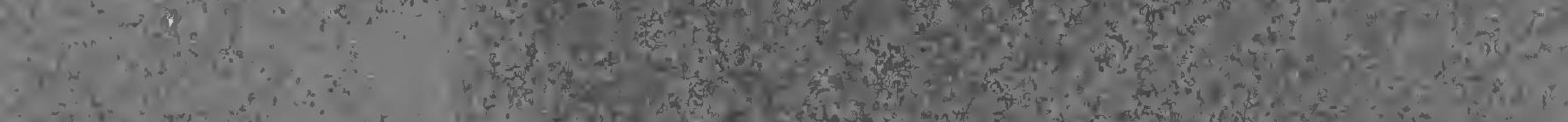
$\therefore=0$

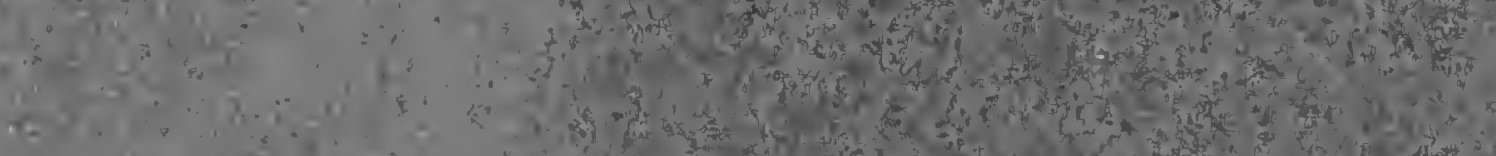
(n)

a

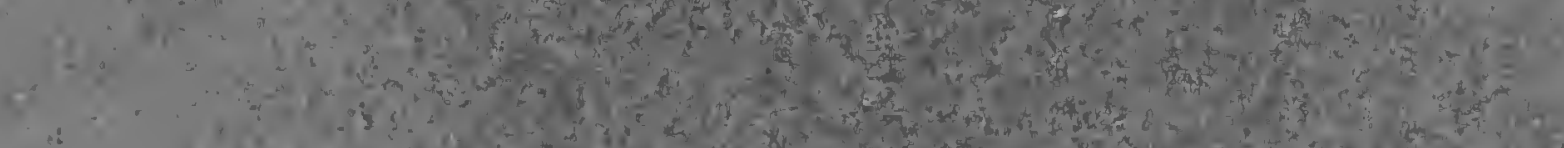

a 


\section{UNIVERSITY OF CALIFORNIA LIBRARY \\ BERKELEY}

Return to desk from which borrowed.

This book is DUE on the last date stamped below.

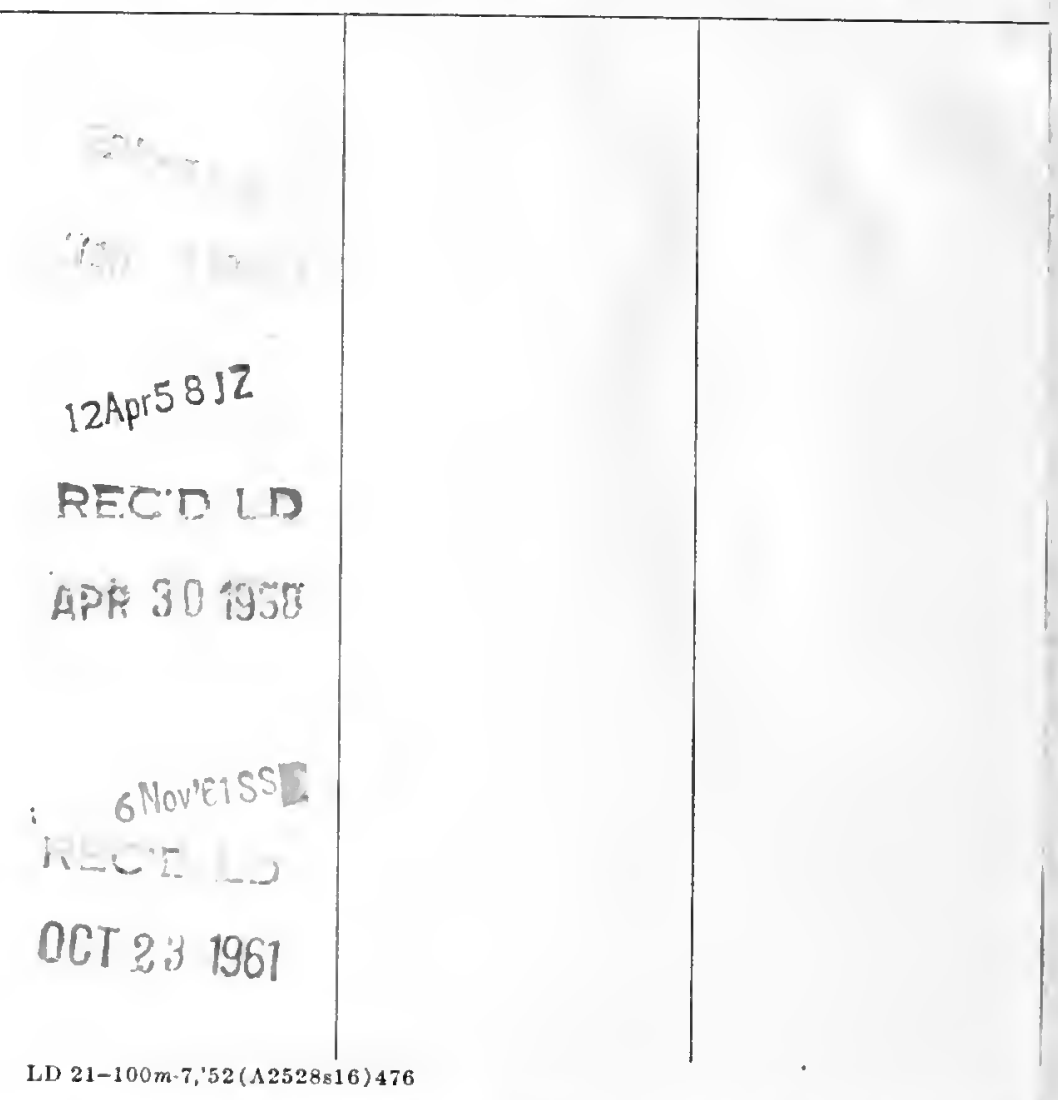




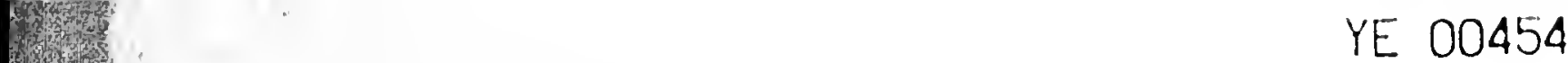


